\author{
Universidade de São Paulo \\ Instituto de Física
}

\title{
Difusão anômala de micropartículas em células no regime de altas frequências
}

\author{
Adriana Valerio
}

Orientador: Prof. Dr. Adriano Mesquita Alencar

Dissertação de mestrado apresentada ao Instituto de Física para a obtenção do título de Mestre em Ciências

Banca Examinadora:

Prof. Dr. Adriano Mesquita Alencar (IFUSP)

Prof. Dr. Henrique Takachi Moriya (Poli-USP)

Prof. Dr. Nathan Bessa Viana (UFRJ) 
FICHA CATALOGRÁFICA

Preparada pelo Serviço de Biblioteca e Informação do Instituto de Física da Universidade de São Paulo

\section{Valerio, Adriana}

Difusão de micropartículas em células no regime de altas frequências. São Paulo, 2017.

Dissertação (Mestrado) - Universidade de São Paulo. Instituto de Física. Depto. de Física Geral

Orientador: Prof. Dr. Adriano Mesquita Alencar

Área de Concentração: Física.

Unitermos: 1. Reologia; 2. Viscoelasticidade; 3. Músculo liso; 4. Lei de potência. 


\author{
University of São Paulo \\ Institute of Physics
}

\title{
Anomalous diffusion of microbeads in cells at a high frequency regime
}

\author{
Adriana Valerio
}

Supervisor: Prof. Dr. Adriano Mesquita Alencar

Disertation submitted to the Institute of Physics of the University of São Paulo in partial fulfillment of the requirements for the degree of Master of Science.

Examining Committee:

Prof. Dr. Adriano Mesquita Alencar (IFUSP)

Prof. Dr. Henrique Takachi Moriya (Poli-USP)

Prof. Dr. Nathan Bessa Viana (UFRJ) 

À memória do meu padrasto Antônio Armando Sandroni, que sempre foi gentil comigo. 



\section{Agradecimentos}

Quero primeiro agradecer à minha família, a minha mãe Benê, meu pai Silvio, meu padrasto Armando, que infelizmente faleceu durante esta etapa de trabalho que foi o mestrado, e ao meu irmão Gustavo. Sem o amor e apoio deles, o processo teria sido muito mais árduo, e agradeço por me incentivarem nos meus objetivos.

Agradeço ao grupo de trabalho do LabM르, ao meu orientador Adriano Alencar por ter me aceitado como aluna, pelas discussões acerca do trabalho e por seu compromentimento no fazer ciência. Agradeço também à colega de sala e amiga Mariana S. Ferraz que acompanhou diversas etapas do trabalho, que me guiou no uso dos equipamentos do laboratório e com quem pude discutir análises feitas, me dando dicas do que eu poderia fazer e na interpretação das análises. Agradeço também aos colegas e amigos do grupo Juan, Isis, Alexandre, Marcel, Caio, Jennifer, Antônio, que é o especialista do laboratório, e professora Lígia. À Isis e Jennifer agradeço principalmente pois nos últimos experimentos feitos elas fizeram toda a parte do cultivo das células que eu utilizei. Além disso, todos me ajudaram na correção e revisão do trabalho, que foram bastante pertinentes.

Agradeço aos meus amigos de graduação e ensino médio por me lembrarem de quem eu sou e o que faz sentido pra mim.

Agradeço à agência CAPES que financiou a minha bolsa de mestrado, à FAPESP e CNPQ que financiaram projetos do laboratório e com eles puderam prover material de consumo de trabalho que eu utilizei no mestrado. Agradeço também ao Instituto de Física por prover um espaço de trabalho, no qual passei boa parte dos dias. 

"O trabalho afasta de nós três grandes males: o tédio, o vício e a necessidade."

Voltaire em "Cândido ou o Otimismo" 



\section{Resumo}

Este trabalho tem como objetivo caracterizar experimentalmente a difusão anômala de microesferas em células com alta resolução temporal. As microesferas são cobertas com um peptídeo para que elas fiquem aderidas ao citoesqueleto celular (CSK), de forma que quando o CSK se movimenta, as microesferas se movimentam junto. A grande parte dos trabalhos na literatura usa técnicas ativas, que consistem em aplicar uma perturbação na célula, para estudar a movimentação das microesferas, diferente da técnica usada neste trabalho, que é passiva. A vantagem de usar a técnica passiva é que é possível olhar a difusão das microesferas, sem haver fatores externos ativos atuando, porque o CSK já é um ambiente sujeito a forças dos próprios motores celulares, o que está relacionado com o comportamento anômalo. Ao calcular o deslocamento quadrático médio (MSD) das microesferas, os regimes aos quais as microesferas estão sujeitas, são o subdifusivo e o superdifusivo, e ambos possuem características que podem ser consideradas comportamento anômalo. Neste trabalho focamos em estudar a difusão anômala a altas frequências, usando uma câmera que pode chegar a 1000 frames por segundo (fps) para observações curtas, ou em torno de 200 fps, sustentável por longos tempos, a fim de evidenciar o comportamento anômalo. Conseguimos mostrar que a movimentação das microesferas segue uma lei de potência para deslocamentos normalizados $|Z|>3$, o que indica que o fenômeno é livre de escala, corroborando com a hipótese de o citoplasma celular ter um comportamento do tipo mole. Além disso, como a análise do movimento é baseada na análise de imagem da posição das microesferas, propusemos um estudo para estimar o erro na posição das microesferas.

Palavras-chave: reologia, viscoelasticidade, músculo liso, lei de potência 



\section{Abstract}

The aim of this master's thesis is to characterize experimentally anomalous diffusion of microbeads in cells with high temporal resolution. The microbeads are coated with a peptide, such that they can bound to integrins, which is a specific cell surface receptor, thus when the cytoskeleton moves the microbeads move together. The majority of works in scientific literature deals with active techniques, that consists of applying a disturbance on the cell, in order to investigate the movement of the beads, differently from the passive technique used in this work. The advantage of using the passive technique is that it makes possible to look to diffusion without having external active factors, because the cell cytoskeleton itself is an environment subjected to forces, provided by cell motors, which has been related to the anomalous behavior in the mean squared displacement. When calculating the microbeads mean squared displacement (MSD), they are subjected to the subdiffusive and supperdifusive regimes, and both have characteristics that can be considered anomalous behavior. Our goal was to study anomalous diffusion at high frequencies by using a camera that reaches up to 1000 frames per second (fps), for shorter observation times, or around $200 \mathrm{fps}$, sustainable for longer observation times, having the purpose of evidencing the anomalous behavior. We were able to show that the microbeads movement follows a power law for normalized displacements $|Z|>3$, indicating that the phenomenon is scale-free, agreeing with the hypothesis that the cellular cytoplasm has a soft glassy behavior. Besides, since the movement analysis is based on the microbeads position image analysis, we have proposed a way to estimate the error in the microbeads position.

Keywords: rheology, viscoelasticity, smooth muscle, power law 



\section{Sumário}

1 Introdução 17

1.1 Contexto . . . . . . . . . . . . . . . . . . . 17

1.2 Objetivo . . . . . . . . . . . . . . . . . . . . . . 18

1.3 Fundamentação Teórica . . . . . . . . . . . . . . . . . . . . . . 18

1.3.1 Citoesqueleto celular . . . . . . . . . . . . . . . . 18

1.3.2 Forças Térmicas e Difusão . . . . . . . . . . . . . . . 21

1.3.3 Movimento Browniano . . . . . . . . . . . . . . . . . 21

1.3.4 Deslocamento Quadrático Médio . . . . . . . . . . . . 22

1.3.5 Reologia e Microrreologia . . . . . . . . . . . . . 22

1.3.6 Citometria Óptica de Torção Magnética (OMTC) . . . . . . . . . . 23

1.3.7 Relação de Stokes-Einstein generalizada . . . . . . . . . . . . . . . . 24

1.3.8 Alguns conceitos em reologia e microrreologia . . . . . . . . . 25

1.3.9 Materiais Vítreos Moles . . . . . . . . . . . . . . . . 26

1.3.10 Invariância de Escala . . . . . . . . . . . . . . . . . . 27

1.3.11 Modelos para o citoesqueleto (CSK) celular . . . . . . . . . 27

2 Materiais e Métodos 229

2.0.12 Preparação de amostras . . . . . . . . . . . . . . . . . . . . . 29

2.1 Análise de Dados . . . . . . . . . . . . . . . . . . . . . 33

2.1.1 Deslocamento Quadrático Médio . . . . . . . . . . . . . . . . 34

2.1.2 Magnitude dos Deslocamentos - Z . . . . . . . . . . . 35

2.2 Análise de Imagens . . . . . . . . . . . . . . . . . . . . . . . . . . . . . . . . 36

2.3 Simulação . . . . . . . . . . . . . . . . . . . . . . . . . . . . . . . . . . . . . 38

2.3 .1 Introdução . . . . . . . . . . . . . . . . . . . . . . . . . 38

2.3.2 Modelo para microesfera . . . . . . . . . . . . . . . . . . 38

2.3.3 Ruído do plano de fundo . . . . . . . . . . . . . . . . . . . 39

2.3.4 Caminhada aleatória $($ Random Walk) . . . . . . . . . . . . . 41

2.4 Resultados e análise . . . . . . . . . . . . . . . . . . . . . . . . . . 42 
2.4.1 Escolhendo parâmetros fixos . . . . . . . . . . . . . 42

2.4.2 Variação do erro com o diâmetro . . . . . . . . . . . . . 43

2.4.3 Variação do ruído com o tempo . . . . . . . . . . . . . 45

2.4.4 Variação do erro com ruído variável . . . . . . . . . . . . . . 46

3 Resultados e Discussão 47

3.0.5 Investigando difusão anômala . . . . . . . . . . . . . . . . 50

3.0.6 Relação cauda versus tempo . . . . . . . . . . . . . . . . . . 52

3.0.7 Correlação na movimentação das microesferas . . . . . . . . . . 555

4 Conclusões

A Atividades Acadêmicas 61

B Microesferas Ferrigmagnéticas 63

C Calibração das Câmeras 65

D Caracterização de CCDs 67

E Protocolos de cultivo de células e de procedimentos para preparo experimental $\quad$ [71

E.1 Descongelamento de células . . . . . . . . . . . . . . . 71

E.2 Cultivo de células . . . . . . . . . . . . . . . . . . . . . . . . . . . 72

E.2.1 Protocolo prévio . . . . . . . . . . . . . . . . . . 72

E.2.2 Manutenção de células em cultura permanente . . . . . . . . . 73

E.2.3 Troca de meio de cultura . . . . . . . . . . . . . . . . . . . 74

E.2.4 Concentração e contagem de células . . . . . . . . . . . . . . . 75

E.2.5 Câmara de Neubauer . . . . . . . . . . . . . . . . . 76

E.3 Preparo de experimentos . . . . . . . . . . . . . . . . . . . . . . 77

E.3.1 Preparo da solução de esferas cobertas com RGD a uma concentração de $2 \mathrm{mg} / \mathrm{ml} \ldots \ldots \ldots \ldots$. . . . . . . . . . . . . . . . 77

E.3.2 Preparo de poços ou placas de Petri para adesão das esferas nas células 78 
Capítulo 1

\section{Introdução}

\subsection{Contexto}

As células são as unidades estruturais básicas dos organismos vivos e são constituídas por uma membrana celular, organelas, material genético e citoesqueleto. Em geral, todo o material intracelular compreendido entre a membrana plasmática e o envoltório nuclear é chamado de citoplasma, que é um ambiente altamente dinâmico cujas funções agregadas dos motores celulares e outros fatores ativos resultam coletivamente nas funções que mantém a célula em pleno funcionamento, tais como divisão, migração e contração celular [19]. O citoesqueleto da célula, junto da membrana plasmática, é a estrutura que mantém o formato da célula, o que permite a ela realizar suas funções, sendo também uma estrutura dinâmica composta de proteínas que podem se polimerizar ou despolimerizar, mudando a forma da célula e dando resistência mecânica à deformação. A determinação do tráfego intracelular é um assunto central em biologia celular pois o ambiente interno das células é sujeito a uma variedade de forças que dão origem a um movimento que coletivamente é direcionado, mas as forças primariamente são aleatórias [19].

Muitos pesquisadores interpretam o movimento aleatório citoplásmico como emergente primariamente de um processo difusivo térmico [19], contudo o citoplasma não é um fluido em equilíbrio térmico. Diversos trabalhos na literatura, como Weitz et al [19] e Bursac et al [10] mediram o deslocamento quadrático médio (MSD) de partículas, respectivamente injetadas no citoplasma celular e no CSK, e encontraram que o movimento não é linear com o tempo, como seria esperado no movimento térmico browniano. Isso é reforçado pelo fato de os eventos anômalos, cujo MSD não é linear com o tempo, desaparecem quando a energia dos motores celulares (ATP [5]) é retirada da célula. Como cita Guo em [19], notou-se uma redução no MSD das partículas de prova, quando foi usada uma droga (blebistatina) que inibe a atividade dos motores miosina II da célula. No trabalho de Bursac [10], também se nota uma redução do MSD quando se depleta ATP da célula. 


\subsection{Objetivo}

O foco principal do trabalho é entender e analisar do ponto de vista experimental a dinâmica de microesferas anexadas ao citoesqueleto das células, objetivando entender o comportamento do citoplasma celular. Em particular, queremos evidenciar a difusão anômala no regime de altas frequências usando uma câmera que consegue chegar a altas taxas de aquisição de imagens: 1000 frames por segundo (fps) para observações curtas, ou em torno de 200 fps, que é sustentável por longos tempos de amostragem. Com relação à tomada de dados em células e análise, foi dada continuidade ao trabalho de doutorado da aluna Mariana S. A. Ferraz, que defendeu sua tese no ano de 2015 [40].

Como objetivo secundário pretende-se estimar o erro produzido pela câmera utilizada na obtenção das imagens das células, pois as medidas dependem de partículas aderidas ao CSK, cujo centro de massa é detectado através de análise de imagem, portanto queremos saber o quanto podemos errar na medida e o quanto isso afeta a interpretação dos dados que obtemos.

Em termos específicos foi feito: a) medição da posição do centro de massa das microesferas anexadas ao citoesqueleto e interpretação da movimentação destas; b) análise da imagem, gerando a imagem de uma esfera ideal e acrescentando ruído, e comparação da imagem com ruído com a imagem ideal para estimativa do erro.

\subsection{Fundamentação Teórica}

\subsubsection{Citoesqueleto celular}

O citoesqueleto é primeiramente responsável por dar a estrutura e rigidez da célula. Ele compreende um sistema de filamentos de proteínas altamente emaranhadas que permeiam o citosol (componente aquoso do citoplasma). Essa matriz fibrosa tem o importante papel de manter funções essenciais da célula, desde migração e adesão à mecanotransdução (sensibilidade que a célula tem em responder com um sinal bioquímico a um estímulo mecânico e vice-versa) [34]. Um exemplo simples de movimento celular é a contração das células musculares; outro menos familiar é o movimento de macrófagos, importante para o sistema imunológico [8]. Os principais componentes do citoesqueleto são os filamentos de actina, filamentos intermediários, e microtúbulos, e as proteínas cross-linking; esta última organiza os filamentos de actina em geis viscoelásticos que se conectam às proteínas transmembrana e complexos sinalizantes localizados nos sítios de adesão intracelular e da matriz extracelular. Dentre esses, os filamentos de actina são os mais abundantes na célula [30].

Filamentos de Actina: a actina é um polímero dinâmico cujo bloco construtor prin- 
cipal é a G-actina, sendo seus terminais sujeitos a polimerização e despolimerização, podendo mudar o comprimento do filamento no processo. Cada terminal do filamento cresce e encolhe a taxas diferentes: o terminal de alto crescimento é chamado de terminal positivo (do inglês "plus end"), enquanto o terminal que cresce mais devagar é denominado negativo ("minus end"). No caso da actina, a microscopia eletrônica mostra que os terminais são um pouco diferentes, com o terminal positivo se parecendo mais com a parte de trás de uma flecha, e o terminal negativo se parecendo mais com a parte da frente [34].

Os monômeros de actina contém ATP (adenosina trifosfato), a qual é hidrolizada para ADP (adenosina difosfato) após polimerização [8].

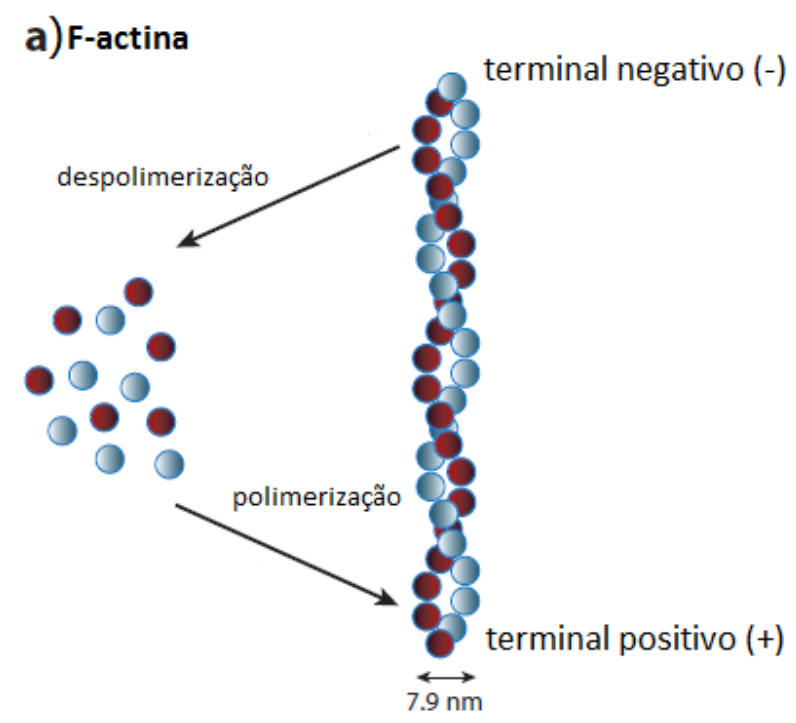

\section{b) Filamento Intermediário}
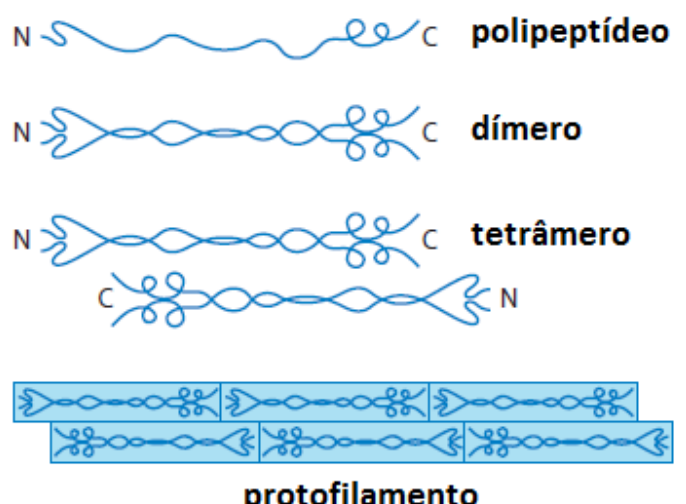

protofilamento
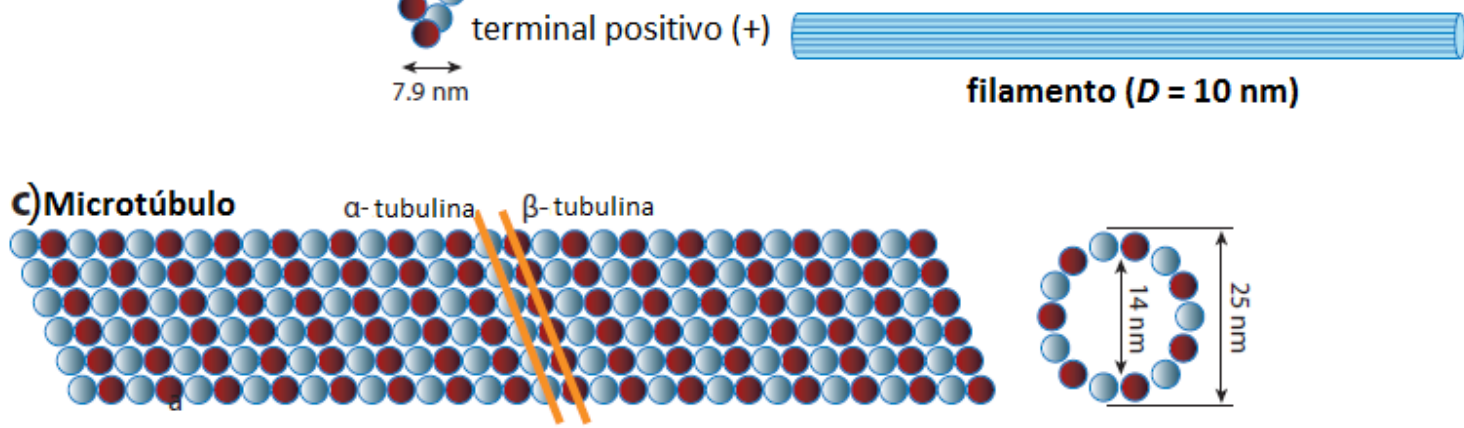

Figura 1.1: Constituintes primários do citoesqueleto: (a) filamentos de actina, (b) filamentos intermediários e (c) microtúbulos. Figura adaptada de [34].

Microtúbulos: também são polímeros dinâmicos, mais até que a actina, podendo acontecer polimerização e despolimerização nos seus terminais, com diferença de velocidade nos dois terminais. O bloco construtor é o heterodímero tubulina, onde os monômeros $\alpha$ - e $\beta$-tubulina são polimerizados em um arranjo que segue uma forma espiralada, que se organiza a formar um cilindro oco. Os filamentos têm um diâmetro externo de aproximadamente $25 \mathrm{~nm}$ e exibem uma alta rigidez à flexão, mais até que do que um filamento de actina, com comprimento de persistência de aproximadamente $6 \mathrm{~mm}$ (isto é, três vezes mais longos que a escala de comprimento da maioria das células). Estruturas tubulares tendem a ser mais resistentes a torções que cilindros sólidos com a mesma quantidade de material por unidade 
de comprimento, que combinados com raios maiores, acrescentam para a alta rigidez a flexão dos microtúbulos, mesmo eles tendo módulo de Young similar ao da actina [34].

No caso da tubulina cada $\alpha$-unidade e $\beta$-unidade contém sítios de ligação GTP (guanosina trifosfato). O GTP na $\beta$-unidade é hidrolizado para GDP (guanosina difosfato) pouco após a polimerização [8].

Filamentos Intermediários: constituem uma família de proteínas contendo mais de 50 membros, que têm em comum uma estrutura consistindo de um domínio central $\alpha$ helicoidal de mais de 300 resíduos que formam uma estrutura em forma de bobina. Os dímeros então se montam em um arranjo escalonado para formar tetrâmeros que se conectam de ponta a ponta, formando protofilamentos. Estes, por sua vez se agrupam em estruturas do tipo corda, com cada uma contendo cerca de 8 protofilamentos e comprimento de persistência de aproximadamente $1 \mu \mathrm{m}$. Os filamentos intermediários se diferem dos microfilamentos e microtúbulos por sua estabilidade de longo prazo e alta resistência a solubilidade em sais. A formação do filamento ocorre sem hidrólise de ATP ou GTP [8, 34].

Comprimento de persistência é o parâmetro mais importante que descreve a resistência de um filamento a forças térmicas, i.e., é o comprimento para o qual as curvas que se formam no filamento devido a fatores térmicos se tornam mais notáveis. Quanto mais flexível o filamento, menor o comprimento de persistência, maior a curvatura, e menor o comprimento de ponta a ponta (Fig. 1.2] [20].

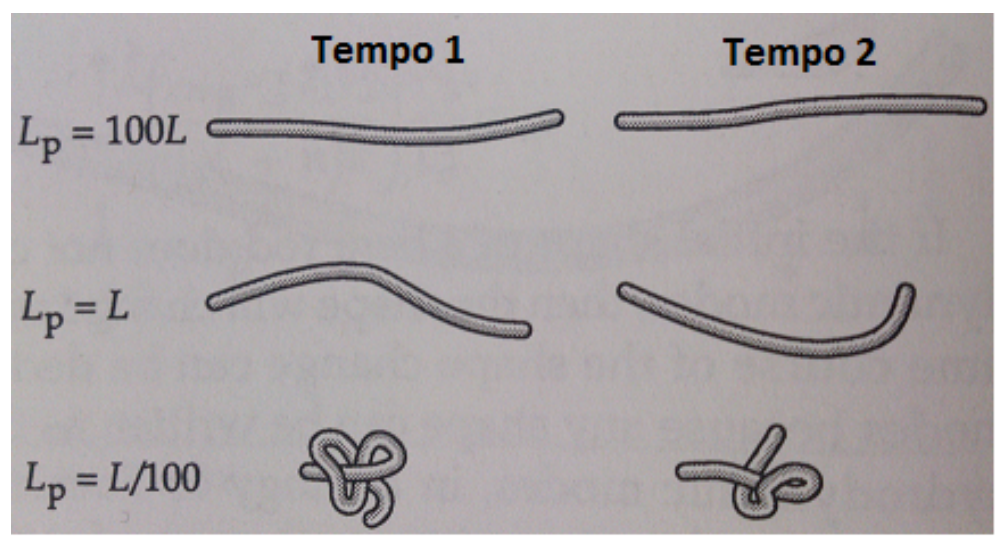

Figura 1.2: Exemplo de comprimento de persistência $\left(\mathrm{L}_{p}\right)$ de um filamento de comprimento L. Figura adaptada de [20].

Estas são algumas das muitas proteínas que contribuem para as propriedades mecânicas da célula e estão primariamente associadas com o citoesqueleto, mas mesmo dentro da rede do citoesqueleto são encontradas outras proteínas (por exemplo ABPs) de ligação que influenciam na força e integridade da matriz resultante. Somam-se ainda os constituintes moleculares da membrana celular, membrana nuclear, e todas as organelas e corpos intracelulares 
que influenciam a resposta mecânica global da célula [35].

Um número de proteínas ligadas a actina (ABPs) são capazes de entrelaçar os filamentos de actina nas redes, e também há um número de proteínas associadas aos microtúbulos (Maps) para fabricar pacotes de microtúbulos. Proteínas especializadas podem deslizar ao longo dos filamentos de actina e tubulina, com a energia a partir da hidrólise de ATP. As proteínas motoras podem ser agrupadas em três famílias: miosinas associadas com actina, kinesinas e dineínas associadas com microtúbulos. Os filamentos de actina e pacotes de miosina podem se organizar em estruturas altamente cooperativas nos músculos [8].

\subsubsection{Forças Térmicas e Difusão}

Proteínas e células estão sujeitas a forças térmicas que surgem a partir de colisões com água e outras moléculas no fluido envolto. Em cada colisão há uma mudança no momento da partícula e as forças transmitidas são ditas térmicas porque a amplitude da força é proporcional à temperatura do fluido, por isso o movimento resultante é denominado térmico; e é aleatório, porque o movimento tem mudanças frequentes e abruptas na direção. A esse movimento aleatório dá-se o nome difusão. A difusão de uma partícula livre ou molécula é chamada de Movimento Browniano (MB) [20].

\subsubsection{Movimento Browniano}

O movimento irregular de grãos de pólen em um fluido foi descoberto e caracterizado pelo botânico inglês Robert Brown, em 1827. Investigações experimentais subsequentes revelaram que o fenômeno é mais geral, ocorrendo em suspensões de diversos tipos de partículas microscópicas em fluidos não muito viscosos. As primeiras teorias sobre o MB publicadas independentemente por Albert Einstein (1905) e por Marian Smoluchowski (1906) representam aplicações de sucesso das ideias atomísticas da teoria cinética dos gases [41]. Posteriormente, outros cientistas deram sua contribuição de forma a dar um novo tratamento às ideias publicadas por Einstein, como Paul Langevin e Adriaan Fokker e Mark Kac [43].

Einstein mostrou que o movimento irregular das partículas suspensas poderia ser entendido como o surgimento a partir da agitação térmica aleatória das moléculas no líquido em volta: essas menores entidades agem ambos como a força motriz para as flutuações brownianas, que é impacto das moléculas do líquido nas partículas maiores, e como meio de amortecimento desses movimentos, através da viscosidade apresentada pelas partículas maiores 36].

As partículas desse movimento estocástico podem ser localizadas pelo vetor de posição $\vec{r}(t)$. Partindo de uma posição inicial $\vec{r}_{0}=\vec{r}_{0}\left(t_{0}\right)$ e dado um intervalo temporal $\Delta t$, a partícula se movimenta para uma nova posição $\vec{r}_{1}=\vec{r}\left(t_{0}+\Delta t\right)$, sendo $\Delta \vec{r}_{1}=\vec{r}_{1}-\vec{r}_{0}$ definido como a diferença entre as duas posições. Generalizando, tem-se que $\vec{r}_{i}=\vec{r}\left(t_{0}+i \Delta t\right)$ e 
$\Delta \vec{r}_{i}=\vec{r}_{i}-\vec{r}_{i-1}$. Sendo $N$ o número total de eventos, o deslocamento quadrático médio (Mean Squared Displacement, MSD) é definido como a média desses deslocamentos ao quadrado: $\left\langle\Delta r^{2}(\Delta t)\right\rangle$, onde $\langle\ldots\rangle$ é a média em relação aos $i$ s. O MSD é caracterizado pelo coeficiente de difusão $D$, que é um valor que representa a facilidade com que um soluto se move em um solvente. Para um MB tridimensional, esse coeficiente é dado por [40]:

$$
D=\frac{\left\langle\Delta r^{2}(\Delta t)\right\rangle}{6 \Delta t}
$$

No trabalho de Einstein, ele encontrou a relação entre o coeficiente de difusão $D$ e viscosidade $\eta$. Assim, $D$ para uma partícula esférica de raio $a$ é dado por:

$$
D=\frac{k_{B} T}{6 \pi \eta a}
$$

onde $k_{B}$ é a constante de Boltzmann e $T$ a temperatura [42]. A equação 1.2 é obtida a partir da equação 1.1 e da lei de Stokes para difusão de partículas esféricas de um fluido com baixo número de Reynolds. A equação 1.1 é obtida a partir da equação de movimento para uma partícula imersa em um fluido, sujeita a um atrito viscoso proporcional à velocidade e a forças de caráter aleatório devido ao impacto da partícula com o meio. Essa é a abordagem de Langevin para para o movimento browniano.

\subsubsection{Deslocamento Quadrático Médio}

Para o cálculo do deslocamento quadrático médio, pode-se decompor $\left(\Delta r_{i}\right)^{2}$ em componentes cartesianas $\left(\Delta x_{i}\right)^{2}$ e $\left(\Delta y_{i}\right)^{2}$. O $\left(\Delta r_{i}\right)^{2}$ ocorre em um certo $\Delta t$, sendo $\Delta t_{i}=i \delta t$, e $\delta t$ é o menor múltiplo de $\Delta t$. O MSD é então a média de todos os passos correspondentes a cada $\Delta t$ :

$$
\left\langle(\Delta r(\Delta t))^{2}\right\rangle=\frac{1}{n} \sum_{i=1}^{n}\left(\Delta r_{i}(\Delta t)\right)^{2}
$$

onde $n$ é o inteiro da divisão $\frac{(N-1) \delta t}{\Delta t}$. Este procedimento é aplicado para todos os $\Delta t$ s até obtermos o MSD para todos os múltiplos de $\delta$ ts.

\subsubsection{Reologia e Microrreologia}

Reologia é o estudo do fluxo de matéria, primariamente em estado líquido, mas também em sólidos moles ou sólidos sob condições nas quais eles respondem em um regime de fluxo plástico [3]. O termo reologia se aplica a substâncias que têm uma estrutura complexa, tais como surfactantes, polímeros, alimentos, aditivos, materiais que tenham uma formação vítrea, fluidos corporais e materiais biológicos [40].

Fluidos Newtonianos são fluidos que podem ser caracterizados por um único coeficiente de viscosidade para uma temperatura específica. Embora essa viscosidade mude com a 
temperatura, ela não muda com a taxa de deformação. Apenas um pequeno grupo de fluidos tem essa viscosidade constante. A ampla classe de fluidos cuja viscosidade muda com a taxa de deformação são chamados de fluidos não-Newtonianos. A reologia então se preocupa em estudar materiais que possam ser classificados como fluidos não-Newtonianos e sólidos com comportamento plástico, isto é, materiais que se deformam permanentemente ao sofrerem suficiente deformação. A propriedade característica dos materiais na reologia é a viscoelasticidade.

A microrreologia é o estudo de propriedades reológicas dos materiais na escala microscópica, que experimentalmente pode ser feita usando dois tipos de técnicas: passiva e ativa. Dentre as técnicas ativas pode-se citar o uso de pinças ópticas, pinças magnéticas, MTC e OMTC (respectivamente, Magnetic Twisting Citometry e Optical Magnetic Twisting Citometry), micropipeta de aspiração, microscopia de força atômica (AFM), e mais recentemente microscopia de força de tração [19, 38], dentre outras. Nas técnicas ativas aplica-se uma distensão ou pressão externa utilizando uma sonda, e mede-se a distensão ou pressão resultante. As técnicas passivas se utilizam das forças térmicas, i.e., proporcionais a $k_{B} T$, para medir o movimento de marcadores, i.e., o rastreamento de partículas injetadas no material; dentre elas tem-se difusão anômala, microscopia de força de tração (TFM), etc.

\subsubsection{Citometria Óptica de Torção Magnética (OMTC)}

O nome da técnica do OMTC vem do inglês: Optical Magnetic Twisting Citometry, na qual o aparato experimental consiste de dois campos magnéticos acoplados a um microscópio invertido, e as amostras utilizadas na medição são células vivas com microesferas ferrimagnéticas depositadas na amostra, que são preparadas de forma que o peptídeo RGD (ver Apêndice E) cubra essas microesferas para que elas possam se aderir ao citoesqueleto da célula. O RGD se adere aos receptores de integrina do citosqueleto, de forma que a microesfera fica presa (Fig. 1.3).
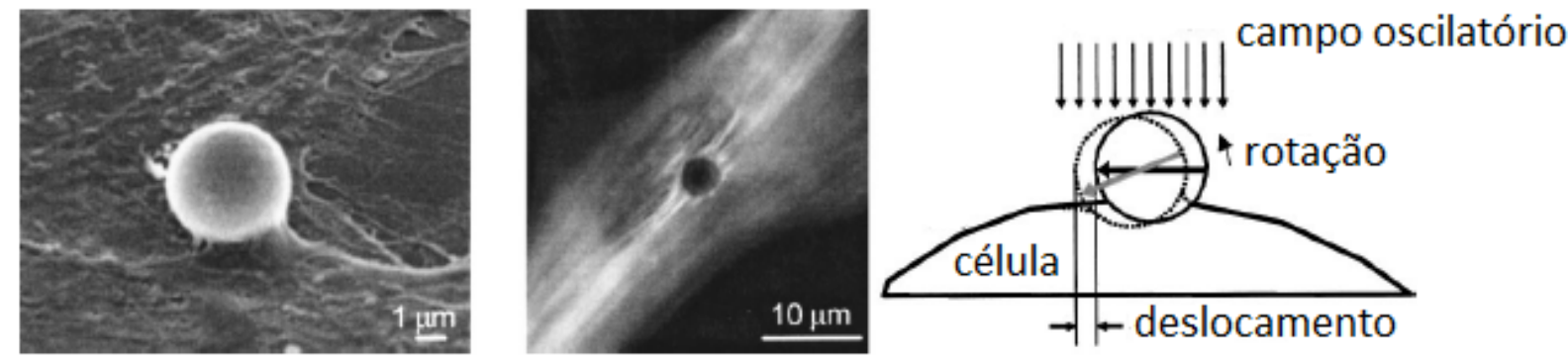

Figura 1.3: (a) Imagem obtida por microscopia eletrônica de uma microesfera presa na superfície de uma célula HASM. (b) Microesfera ferrimagnética coberta RGD presa nos filamentos de actina do citoesqueleto. (c) Esquema de funcionamento do OMTC, as setas compridas indicam a direção do momento magnético das microesferas antes (preto) e depois (cinza) de aplicado o campo oscilatório. Figura adaptada de [15].

As microesferas são magnetizadas horizontalmente por um primeiro campo magnético, e então é aplicado verticalmente um outro campo magnético externo homogêneo, que varia 
senoidalmente no tempo gerando um torque nas microesferas, o que causa rotação das esferas no sentido de se alinharem com o campo (Fig. 1.3). A rotação das esferas tende a ser impedida pelas forças mecânicas que se desenvolvem dentro da célula. Um sistema de aquisição e processamento de imagens é integrado ao microscópio invertido para acompanhar o movimento das microesferas. O torque $T$ é o torque mecânico por volume de esfera e tem dimensão de pressão $(\mathrm{Pa})$. Durante o processamento das imagens, o programa marca a posição do centro de massa das esferas, de modo que é possível saber os deslocamentos que as microesferas tiveram. Com a técnica do OMTC é possível medir a o módulo complexo viscoelático complexa do citoplasma celular, pois:

$$
G^{*}(\omega)=G^{\prime}(\omega)+i G^{\prime \prime}(\omega)=\frac{T^{*}(\omega)}{d^{*}(\omega)},
$$

onde $T^{*}$ é a transformada de Fourier do torque aplicado, $\omega$ é a frequência do campo aplicado, $d^{*}$ é o deslocamento da microesfera e $G^{*}$ a grandeza complexa que caracteriza a viscoelasticidade do material. A técnica de OMTC já está consolidada no LabM².

\subsubsection{Relação de Stokes-Einstein generalizada}

Em fluidos complexos, a viscosidade é complexa $\left(\eta^{*}\right)$ e dependente da frequência $(\omega)$ : $\eta^{*}(\omega)$. A relação de Stokes-Einstein que foi desenvolvida pensando primariamente em fluidos Newtonianos, não pode ser usada para fluidos complexos. Assim foi desenvolvida a relação de Stokes-Einstein generalizada (generalyzed Stokes-Einstein relation, GSER), que diz que é possível encontrar o MSD em termos de $G^{*}(\omega)$, que é o módulo complexo viscoelástico:

$$
G^{*}(\omega)=\frac{k_{B} T}{\pi a(i \omega) \mathscr{F}_{u}\left\{\left\langle r^{2}(\Delta t)\right\rangle\right\}}
$$

onde $\mathscr{F}_{u}$ é a transformada unilateral de Fourier do MSD, sendo válida para $\omega>0$ [29], e $a$ é o raio da partícula. A GSER é válida para um material viscoelástico dependente da frequência. É válida somente para sistemas em equilíbrio térmico, onde movimentos casuais são apenas dirigidos por forças térmicas.

A rigor, $G^{*}(\omega)$ é chamada de módulo complexo de cisalhamento, sendo essa uma das representações existentes para quantificar a resposta linear viscoelástica de um material, com todas as representações podendo ser reformuladas em termos de uma função escalar, que é o relaxamento de tensão: $G_{r}(t)$. Representando $G_{r}(t)$ no domínio de frequência de Fourier tem-se: $G^{*}(\omega)=i \omega \mathscr{F}_{u}\left\{G_{r}(t)\right\} \equiv i \omega \int_{0}^{\infty} d t^{\prime} G_{r}\left(t^{\prime}\right) e^{-i \omega t^{\prime}}$. Como $G^{*}(\omega)$ é complexa, ela pode ser separada em partes real $G^{\prime}$ e imaginária $G^{\prime \prime}$, que obedecem às relações de KramersKroning [27+29].

A GSER pode ser obtida através da equação de Langevin generalizada para uma partícula sujeita a uma força aleatória [29], de onde se deriva uma função de memória que se relaciona com a viscosidade complexa $\eta^{*}(\omega)$, de onde se obtém $G^{*}(\omega)$ a partir de $G^{*}(\omega)=i \omega \eta^{*}(\omega)$. 


\subsubsection{Alguns conceitos em reologia e microrreologia}

Na equação 1.4 os termos $G^{\prime}=\mathbb{R e}\left\{G^{*}\right\}$ e $G^{\prime \prime}=\operatorname{Im}\left\{G^{*}\right\}$ são respectivamente o módulo de armazenamento e módulo de perda; o primeiro está relacionado com a parte elástica do material, e o segundo com a parte viscosa. Nessa mesma equação, $i$ é o número imaginário usual.

A matéria pode ser encontrada em várias formas, sendo os casos extremos os sólidos elásticos descritos pela lei de Hooke (1678) e os fluidos viscosos, descritos pela lei de Newton (1687) [40]. A tensão por cisalhamento (shear stress) dada por $\sigma$ é a força aplicada por unidade de área:

$$
\sigma=\frac{F}{A}
$$

e a deformação por cisalhamento $\gamma$ (shear strain) é dada por (Fig. 1.4):

$$
\gamma=\frac{d x}{y}
$$

sendo a deformação cisalhante causada pela tensão por cisalhamento. Em um sólido de Hooke, para uma pequena deformação por cisalhamento, tem-se:

$$
\sigma=\frac{G}{\gamma}
$$

onde $G$ é o módulo de cisalhamento. No SI a tensão é dada em Pa, a deformação é adimensional, e portanto $G$ também é dado em Pa. Apesar de as equações 1.6, 1.7 e 1.8 estarem escritas de forma linear, as grandezas $\sigma$ e $\gamma$ são tensoriais.
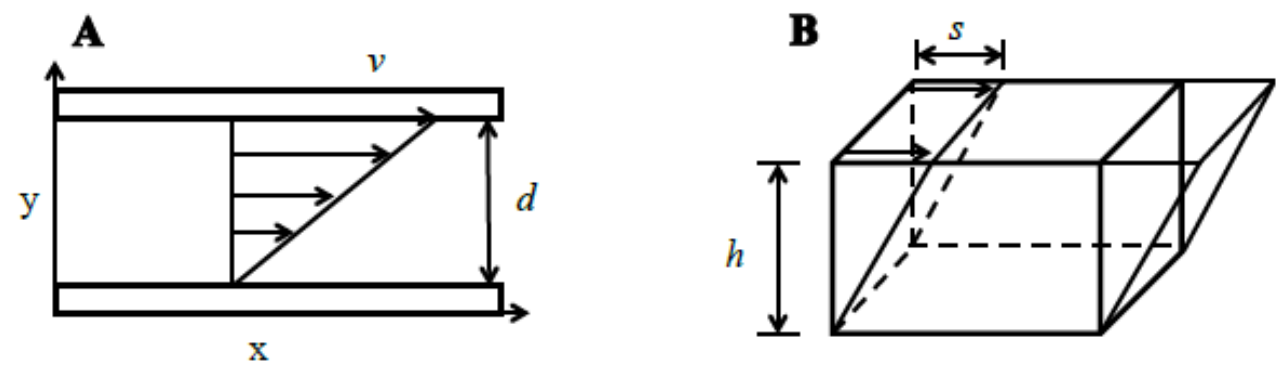

Figura 1.4: (a) Cisalhamento de um fluido entre duas placas planas paralelas separadas por uma distância d, onde a placa superior se move com uma velocidade v com relação à placa inferior. (b) Cisalhamento de um bloco retangular sólido, com altura h e um deslocamento s da superfície em relação à inferior. [13, 40.

Em um sólido de Hooke, quando a tensão é removida do material, a deformação do material cessa voltando ao seu estado original. O caso análogo é para um líquido Newtoniano, que consiste de um líquido entre duas superfícies com uma pequena separação entre si, uma das superfícies é mantida fixa, enquanto a outra pode se mover com velocidade constante. Ao aplicar-se uma tensão constante, há uma deformação permanente dependente do tempo no material dada por: 


$$
\sigma=\eta \dot{\gamma}
$$

sendo $\eta$ a viscosidade do fluido e $\dot{\gamma}=d x / d t .1 / y$ a taxa de cisalhamento (Fig. 1.4). Como $\dot{\gamma}$ é dado por $\mathrm{s}^{-1}$, a viscosidade fica Pa.s, também conhecido como Poiseuille ou Poise (P) no sistema CGS [40].

\subsubsection{Materiais Vítreos Moles}

A classe de materiais vítreos moles (Softy Glassy Materials, SGM) compreende um grupo diverso de susbstâncias, dentre as quais estão espumas, pastas, coloides, emulsões, etc. O comportamento mecânico dessas substâncias é muito parecido. O critério empírico comum que define essa classe de materiais é que eles são muito moles (pressão/torque na ordem de $\mathrm{Pa}$ a $\mathrm{kPa}$ ), e que ambos $G^{\prime}$ e $G^{\prime \prime}$ aumentam com uma lei de potência fraca dependente da frequência, e que a tangente de perda $\left(\eta^{\prime}=G^{\prime \prime} / G^{\prime}\right)$ não é sensível a frequência e é da ordem de 0.1 [18, 44]. Como B. Fabry argumenta em [14] os dados de $G^{\prime}, G^{\prime \prime}$ e $\eta^{\prime}$ obtidos em seu trabalho com células HASM (human aortic smooth muscle, músculo liso de artéria humana) são consistentes com essas características apresentadas por SGM. Neste trabalho ([14]) foi medido $G^{\prime}, G^{\prime \prime}$ e $\eta^{\prime}$ utilizando a técnica de MTC (Magnetic Twisting Citometry, citometria de torção magnética) para micropartículas ferrimagnéticas depositadas no citoplasma de células vivas, técnica similar à do trabalho apresentado nessa dissertação.

P. Sollich é quem propõe trabalhar com a hipótese de que o citoesqueleto das células é do tipo SGM [18]. As características gerais que os materiais vítreos moles compartilham é que cada sistema é composto de elementos que são discretos, numerosos e se agregam via interações atrativas fracas. Além disso, esses materiais existem fora do equilíbrio termodinâmico e são dispostos em uma geometria microestrutural que é inerentemente desordenada e meta-estável, e o citoesqueleto de células compartilha dessas mesmas características [18].

Bouchad apresentou o primeiro estudo teórico para desordem estrutural e configurações meta-estáveis em vidros de spin. A teoria considera um sistema finito desordenado extremamente "áspero", com muitos mínimos locais que correspondem a configurações ou estados meta-estáveis. Os mínimos locais são envoltos por altas barreiras de energia, deste modo os estados são considerados "armadilhas" nos quais o sistema é mantido durante certo período de tempo $\tau$. Essas armadilhas são regiões que precisam atingir uma energia mínima para que sistema mude de estado [34].

Inspirado por essa ideia, Sollich propôs o modelo SGR (softy glassy rheology, reologia de materiais vítreos) para SGMs. Esse modelo considera que o material consiste de um grande número de elementos que estão presos por seus vizinhos. Cada elemento individual vê uma topografia de várias profundidades de energia, que quando ativadas podem saltar de sua configuração atual para outra configuração. A ativação em vidros é geralmente 
de natureza térmica, entretando Sollich afirma que em SGMs a ativação térmica é muito pequena comparada às energias típicas necessárias para que possa haver esses saltos. Assim, ele considera que a ativação resulta da interação entre os elementos, onde rearranjos em um local implica rearranjos em outro local. Fabry fala em [14] que falta uma noção clara da fonte de ativação para os rearranjos, não obstante, essa ativação pode ser representada por uma temperatura efetiva, ou nível de ruído.

Para descrever a deformação e fluxo de material, Sollich incorpora graus de tensão de liberdade para os elementos. Os resultados desse modelo a partir de simulações numéricas mostram leis de potência para os módulos de armazenagem e perda viscoelásticos [34].

Uma das críticas que existe ao modelo de tratar a célula como um meio contínuo viscoelástico, é que os modelos precisam de alguma forma incorporar o entendimento do campo de forças ou tensão do CSK, devido a contratibilidade que a interação actina-miosina oferece na formação das fibras de tensão (estresse) [34].

\subsubsection{Invariância de Escala}

Grande parte dos trabalhos na literatura científica usa métodos de perturbação na célula para medir a resposta viscoelástica do citoplasma, que são técnicas ativas. B. Fabry em [15] propõe como modelo para seus dados uma equação que é a lei de amortecimento estrutural, que dá o módulo complexo de cisalhamento $G^{*}$ em termos de $\omega^{x-1}$, com $x$ sendo o parâmetro que indica a temperatura efetiva, o mesmo parâmetro proposto na teoria de SGM, e $\omega$ a frequência usada na técnica experimental. Nos trabalhos [14, 15] Fabry encontra que $G^{\prime}$ e $G^{\prime \prime}$ aumentam fracamente com uma lei de potência para baixas frequências $(\omega<10$ Hz). Em outros trabalhos como em Fredberg ([18]), Deng ([11]) e Bursac ([10]), também se encontrou que $G^{\prime}$ e $G^{\prime \prime}$ aumentam com uma lei de potência fraca, o que indica que o comportamento viscoelástico nas células utilizadas é livre de escala com o tempo. Os elementos na estrutura do material não são capazes de escapar do próprio poço de potencial quando $x=1$, caso em que o sistema é perfeitamente elástico, e quando $x>1$, os elementos podem saltar aleatoriamente na região com diferentes potenciais, e como resultado o sistema pode fluir e se tornar desordenado [14]. Quando $x=2$ o sistema tem um comportamento do tipo fluido [40]. Fluidez e desordem são características essenciais de materiais vítreos [14]. Foi mostrado também em [6, 40] que o citoesqueleto se remodela conforme as leis empíricas típicas de abalos sísmicos, que seguem leis de potência.

\subsubsection{Modelos para o citoesqueleto (CSK) celular}

Existem diversos modelos computacionais para a reologia do citoesqueleto e mecânica, indo desde modelos contínuos a discretos, bem como diversas técnicas experimentais, que em geral são técnicas que envolvem perturbação na célula. As medidas experimentais providas por essas técnicas, juntamente das técnicas computacionais fizeram surgir várias teorias 
que descrevem a mecânica de células vivas, dentre elas: modelar o CSK como um material contínuo elástico, viscoelástico, ou poroviscoelástico; como um gel poroso ou SGM; modelagem baseada em filamentos de actina; tensegrity (tension-integrity, tensão-integridade), um modelo de rede que incorpora elementos discretos estruturais que suportam compressão.

As disparidades entre esses modelos se devem a diferenças da escala de comprimento e interesse biomecânico. Um dos desafios é como relacionar as observações experimentais com os modelos teóricos e fenomenológicos.

Células podem ser vistas como um meio contínuo se o menor comprimento da escala de interesse é muito maior que as dimensões da microestrutura. Um exemplo disso é a deformação que ocorre em citometria com aparatos magnéticos, onde o tamanho dos beads e a deformação resultante é muito maior que o tamanho da rede do CSK e não é preciso se preocupar com a distribuição dos filamentos de proteína no citoesqueleto, o que permite que essa seja uma aplicação bem sucedida de um modelo contínuo viscoelástico.

O CSK tem mostrado exibir comportamento que segue uma lei de potência, o que implica em um número infinito de escalas de tempo. Alguns trabalhos como em [15, 24] capturam essa dinâmica. A limitação desse tipo de modelo, e também por não ser um objetivo, é que ele não faz muitas previsões a respeito das forças ou distribuição da tensão dentro da célula. Para se obter essas previsões outras técnicas precisam ser utilizadas [34]. 


\section{cantuo 2}

\section{Materiais e Métodos}

Com o intuito de estudar a difusão de anômala de microesferas ferrimagnéticas em células foram preparadas amostras de células de músculo liso arterial com microesferas. As etapas do processo são descritas nas seções seguintes com mais detalhes, na ordem em que elas acontecem no laboratório. De modo geral, o processo envolve cultivar as células em um substrato acrílico adequado, que são os pocinhos (ver Fig. 2.2c), e o cultivo ocorre no próprio laboratório do $\operatorname{LabM}^{2}([1])$. Para realizar o experimento são preparadas as amostras de células, onde são depositadas nelas as microesferas. Após as células adquirirem pelo menos $60 \%$ de confluência, o conteúdo de cada pocinho (células + microsferas) é visualizado utilizando um microscópio invertido com uma câmera CMOS acoplada e ligada a um computador. São feitos filmes, que são sequências de imagens, e o computador armazena essas imagens que serão utilizadas posteriormente na análise. O tempo da filmagem da amostra e tamanho da imagem podem ser escolhidos pelo usuário.

\subsubsection{Preparação de amostras}

Cultivo de células: As células utilizadas foram RASM (rabbit aortic smooth muscle) obtidas em cooperação com o InCor/HC/FMUSP (Instituto do Coração no Hospital das Clínicas da Faculdade de Medicina da USP), com quem o Laboratório LabM² tem parceria. As células são trazidas congeladas e no $\mathrm{LabM}^{2}$ elas podem ser mantidas congeladas em nitrogênio $\left(\mathrm{N}_{2}\right)$ líquido, descongeladas ou congeladas novamente, ou ainda colocadas em cultura. Os protocolos de manutenção de células em cultura se encontram no Apêndice E. Depois que elas são colocadas em cultura elas são mantidas em uma incubadora a $37^{\circ} \mathrm{C}$ e ar com 5\% de $\mathrm{CO}_{2}$ e humidade controlada. Utiliza-se meio de cultura DMEN high glucose. As células se aderem ao fundo da garrafa de cultura (Fig. 2.2a formando um tapete celular, processo conhecido como confluência, onde as células consomem meio que tem nutrientes para que elas se mantenham vivas e possam se multiplicar. A cada dois dias troca-se o meio de cultura no qual as células estão sendo cultivadas, além da garrafa de cultura; cada vez que se troca de garrafa fala-se que houve uma passagem. Essa característica é relevante pois 


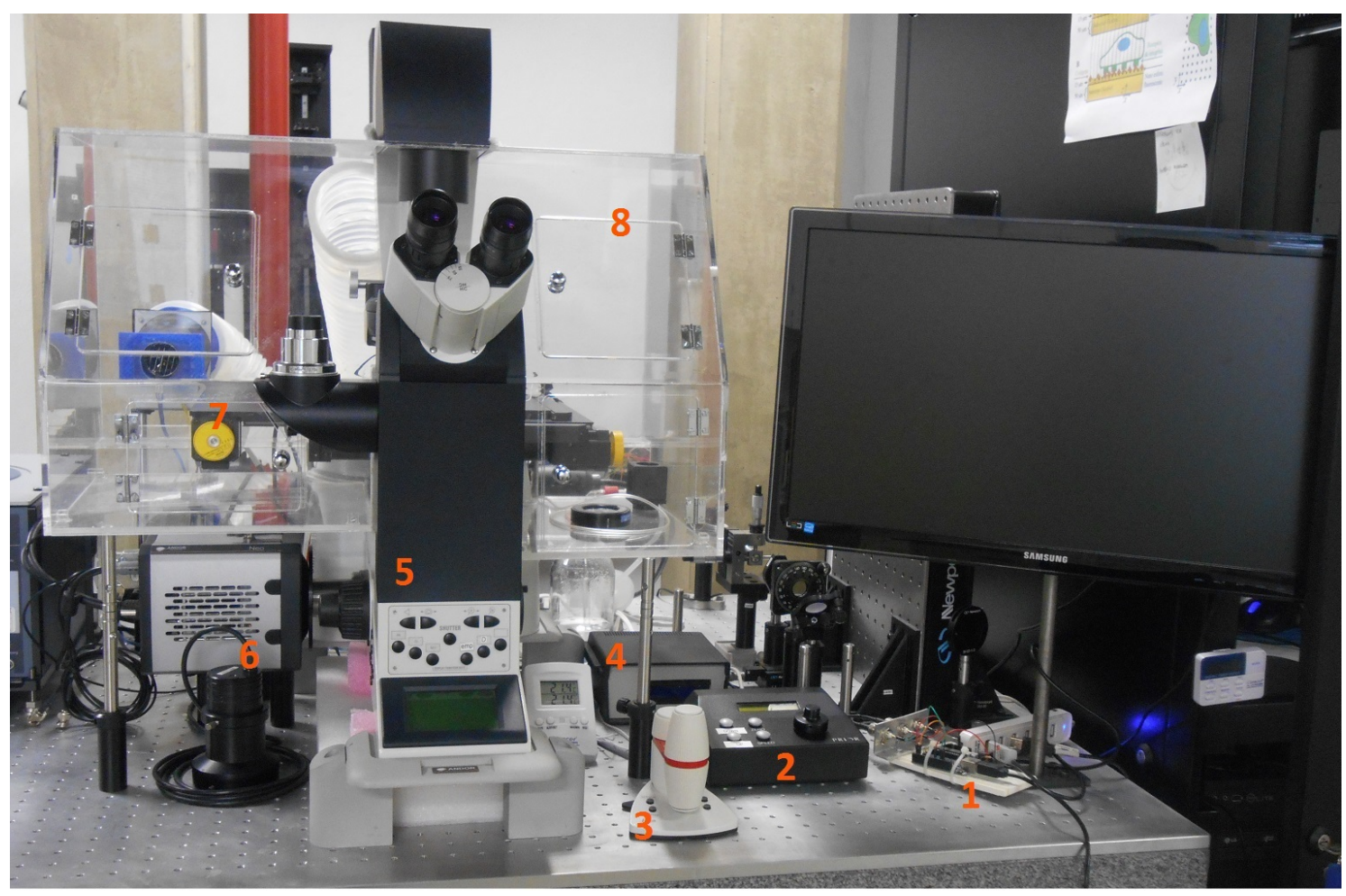

Figura 2.1: Montagem do equipamento experimental: (1) Microcontrolador ATMega 328 que faz o trigger da câmera; (2) controle do eixo z do microscópio; (3) controle dos eixos x e y; (4) aquecedor; (5) microscópio Leica DMI 4000B; (6) câmera Andor neo sCMOS; 7 ) estágio motorizado do microscópio; (8) incubadora construída em volta do microscópio em acrílico e que simula as condições da incubadora na qual as células são mantidas.

cada tipo de célula suporta um número diferente de passagens, após esse limite as células podem sair da região de normalidade do seu comportamento. Nos experimentos utilizam-se células RASM que estejam na sétima passagem.

Preparação de microesferas: Foram utilizadas microesferas ferrimagnéticas de 3.58 $\mu \mathrm{m}$ de diâmetro, cujas informações mais detalhadas estão no Apêndice B, que são recobertas com o peptídeo RGD, que é o ácido arginil-glicil-aspártico, seguindo protocolo de preparação que se encontra no Apêndice E. O RGD se adere à célula via receptores de integrina, fazendo com que as microesferas fiquem fixas no citoesqueleto da célula. Com isso, avaliando a movimentação da microesfera, estamos observando a movimentação do citoesqueleto da célula. As microesferas foram adquiridas de Harvard School of Public Health.

Preparação das amostras para os experimentos: Um dia antes do experimento inicia-se o processo de preparação das amostras. Na passagem das células, ao invés de elas irem para outra garrafa, elas são colocadas em placas de Petri (Fig. 2.2b) ou poços de cultivo (Fig. 2.2c). A partir de 24 horas as células atingem confluência, que é um estado em que se formou um tapete celular que cobre de $90 \%$ a $100 \%$ do fundo da superfície; quando as células atingem de $70 \%$ a $80 \%$ de confluência é o período ideal para se realizar os experimentos (o 
protocolo de preparação encontra-se nos Apêndice E).

Para o experimento deposita-se em torno de 20000 microesferas em cada poço de cultivo (pocinho). A seguir as amostras são incubadas por aproximadamente 20 minutos para que as microesferas possam se aderir ao citoesqueleto da célula. Após esse tempo as amostras já podem ser levadas ao microscópio.

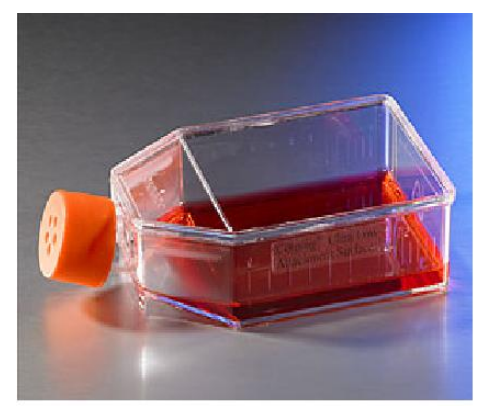

(a) garrafa de cultura com meio dentro

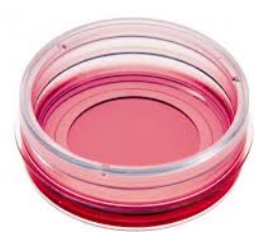

(b) placa de Petri com $\varnothing=35 \mathrm{~mm}$

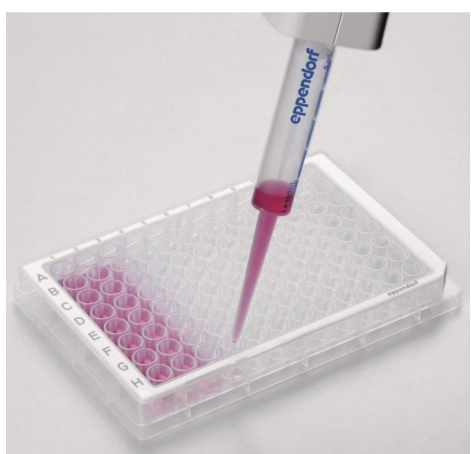

(c) 96 poços de cultivo

Figura 2.2: Exemplo de materiais utilizados para cultura de células. Imagens retiradas da internet.

Setup experimental: Utilizou-se um microscópio invertido Leica DMI 4000 B e uma câmera CMOS (complementary metal oxide semiconductor) anexada ao microscópio (Fig. 2.1) é ligada a um computador para observação das amostras. O programa utilizado para visualizar e gravar as imagens é o Micro-Manager [4] que é um programa aberto. Foi desenvolvido no LabM ${ }^{2}$ o sistema embarcado utilizando o microcontrolador ATmega 328 usando ANSI C++ que faz o trigger externo da câmera. O programa original da câmera faz com que a precisão temporal da câmera fique na ordem de milisegundos (ms), que é uma limitação do próprio sistema operacional. Com o controle feito pelo microcontrolador essa precisão aumenta para ordem de microsegundo $(\mu \mathrm{s})$, fazendo com que a câmera possa tirar fotos com uma frequência de $1000 \mathrm{fps}$ (frames per second, ou fotos por segundo). Apesar de a câmera poder chegar a 1000 fps com boa precisão, por conta da limitação da memória RAM, o alcance de trabalho factível é por volta de $250 \mathrm{fps}$. O tempo de abertura do obturador foi mantido fixo em $300 \mathrm{~ms}$ em todos os experimentos. O diferencial deste trabalho é o microcontrolador desenvolvido para fazer o trigger externo da câmera, com ele é possível garantir que o intervalo com que câmera tira as fotos é mais uniforme quando se aumenta a amostragem da câmera, ou seja, o número de fotos que ela consegue tirar por segundo. Supondo que se quisesse que a câmera tivesse uma amostragem de 100 fps (Figura 2.3), o microcontrolador garante que as fotos sejam tiradas no instante certo. Experimentalmente notou-se que sem o microcontrolador, como é mostrado no trabalho de doutorado da aluna Mariana S. A. Ferraz [40], por conta de as fotos não serem tiradas com intervalo uniforme entre elas, quando se toma frequências de amostragem mais rápidas, o dado que se quer 
obter facilmente se confunde com ruído.

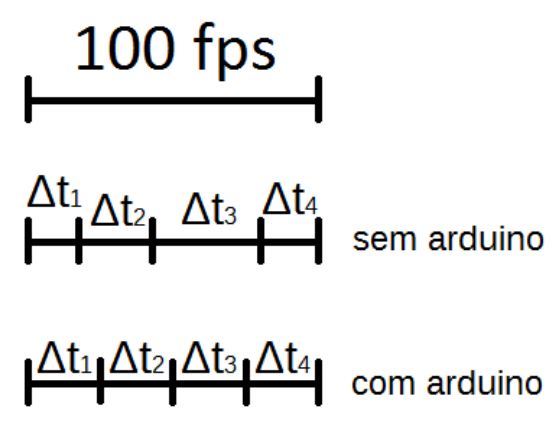

Figura 2.3: Ilustração da ação do microcontrolador que faz o trigger da cêmera, uniformizando o intervalo com que as fotos são tiradas.

Tomada de dados: Coloca-se a amostra no microscópio e configura-se um padrão de tomada das imagens no Micro-Manager. O que se faz é gravar um filme, que é uma sequência de imagens, com uma frequência de aquisição de imagens que o usuário pode escolher (fps). O experimento de difusão é realizado em temperatura ambiente, isso é feito para poder comparar com outros trabalhos na literatura, que também são realizados em temperatura ambiente; como as células estão vivas observa-se a movimentação que está acontecendo em tempo real na célula. Define-se um número de imagens que se quer observar, para os experimentos desse trabalho foi escolhido fazer filmes com 8200, o que corresponde a um certo tempo de observação, a depender da escolha do usuário, que escolhe a taxa com a qual a câmera tirará as fotos, e a seguir as imagens são gravadas no computador para análise posterior. Um fator importante que é limitante para o experimento é que o número de imagens é limitada pois no momento da gravação utiliza-se a memória RAM da câmera, que é limitada. Nos experimentos desse trabalho foram escolhidas magnificações de 10 vezes e 20 vezes. As correspondências dos aumentos com o tamanho real estão no Apêndice C.

Análise de imagens: Após adquiridas as imagens, um programa desenvolvido no próprio LabM $^{2}$ realiza a análise delas. O que o programa faz é procurar o centro de massa das microesferas com base na intensidade dos pixels da imagem. Como a imagem é composta de tons de cinza, e as microesferas ferrimagnéticas ficam bem mais escuras na imagem (ver Fig. 2.4). Ao definir alguns parâmetros no programa da análise das posições, ele classifica quais são as microesferas e grava as coordenadas do centro de massa em um arquivo ".txt". O programa utilizado é o mesmo usado no OMTC (seção 1.3.6) que realiza as análises das posições das microesferas. 


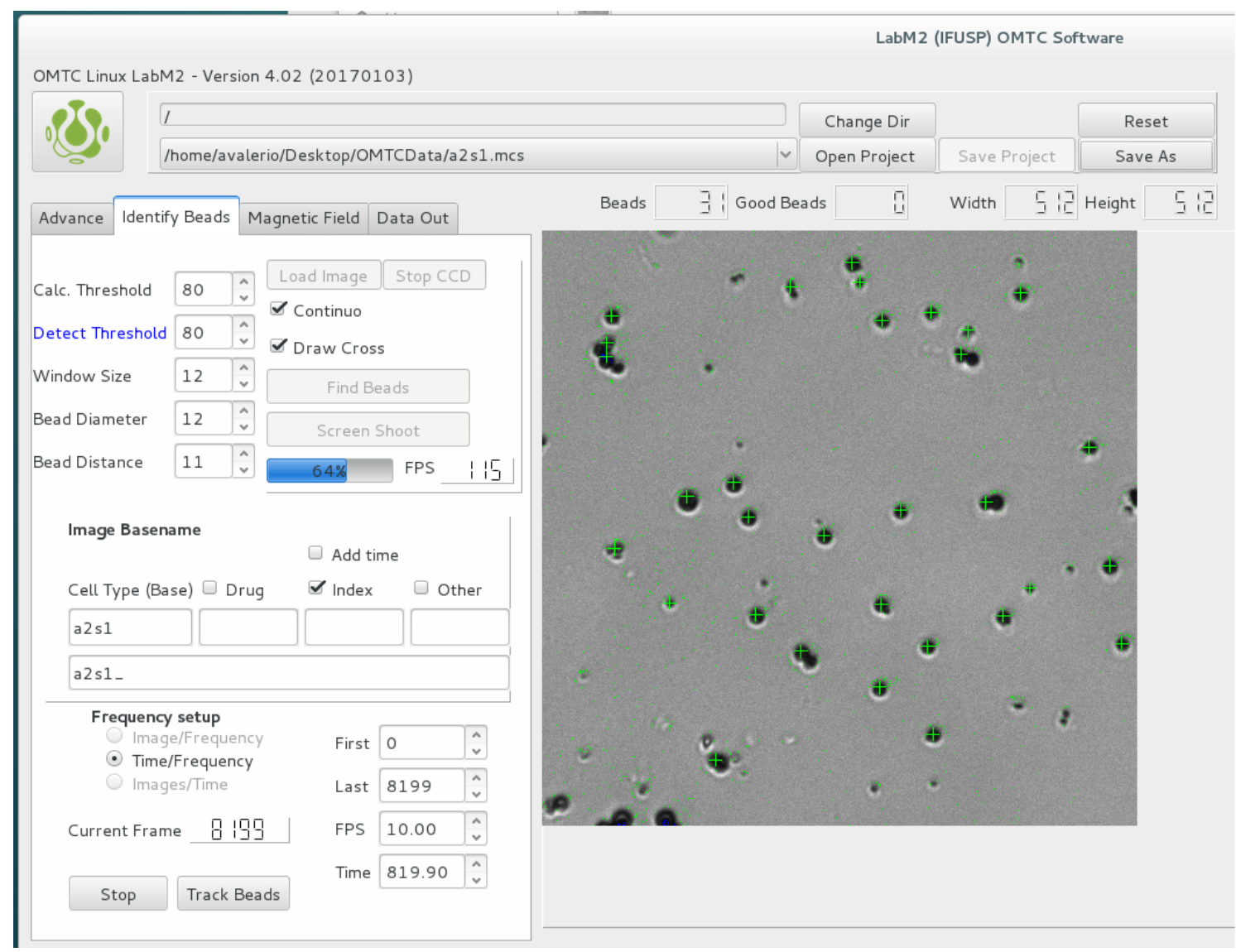

Figura 2.4: Exemplo da interface do programa que analisa as imagens. Imagens de tamanho 512 x 512 pixels, as microesferas são as esferas em preto na imagem, as cruzes em verde na imagem é onde o programa marca o centro de massa.

\subsection{Análise de Dados}

Cada tomada de imagens consegue detectar em torno de 40 microesferas por pocinho devido a magnificação do microscópio, por isso são feitas aquisições de diferentes regiões das amostras. Cada aquisição gera um arquivo de texto diferente, de forma que para cada Grupo Experimental tem-se por volta de 10 arquivos de texto contendo as posições dos centros de massa (CM) das microesferas, que depois de analisados pode-se reunir os resultados. O número dos arquivos de texto em cada Grupo Experimental pode variar de 8 a 10 arquivos.

Na preparação das amostras pode acontecer de algumas microesferas ficarem aglomeradas ou umas muito próximas das outras. Para a análise, essas microesferas que estão nesses dois tipos de configurações não são levadas em consideração. Pode-se ver um exemplo da trajetória de uma microesfera na Fig. 2.5.

Tendo o arquivo de dados com as posições das microesferas em cada instante de tempo $t_{i}$, calcula-se o deslocamento das microesferas $\Delta x_{i}=x_{i}-x_{i-1}$ correspondente a cada $\Delta t_{i}$ $=t_{i}-t_{i-1}=$ constante, com $i$ sendo o índice da série temporal. Esse procedimento é feito independentemente para eixos x e y. Para tratamento dos dados subtrai-se o movimento de deriva, que é o deslocamento médio por tempo, para evitar efeitos do movimento coletivo 


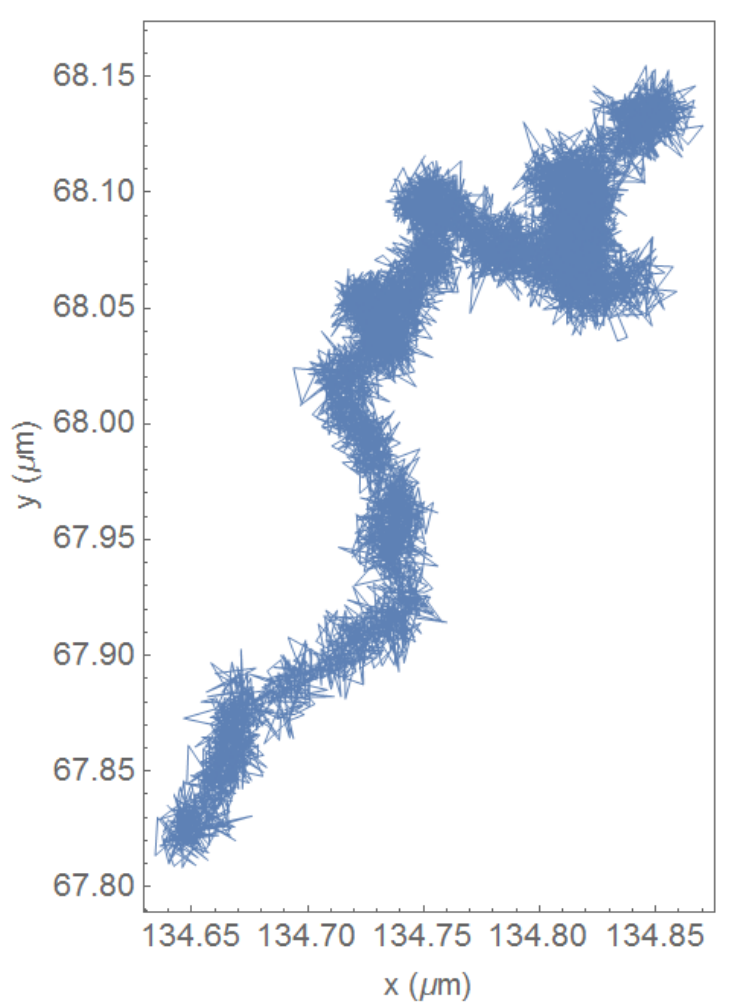

Figura 2.5: Exemplo da trajetória com 8200 passos feita por uma microesfera. A correspondência no movimento da microesfera nesse caso é de $0.324 \mu \mathrm{m} /$ pixel (ver Apêndice C).

que ocasionalmente ocorre devido ao deslocamento micrométrico do estágio do microscópio. O deslocamento corrigido com a deriva é definido pela Eq. 2.1, e o segundo termo da direita é o que representa a deriva, $N$ é o número de microesferas total do arquivo de dados.

$$
\Delta \tilde{x}_{i}(t)=\Delta x_{i}(t)-\frac{1}{N} \sum_{i=1}^{N} \Delta x_{i}(t)
$$

A equação acima está escrita para a coordenada $x$ das esferas, a correção é análoga para coordenada $y$. A fim de quantificar a movimentação das microesferas foi feito um programa na plataforma Mathematica que calcula o deslocamento quadrático médio (do inglês, Mean Squared Displacement, MSD) e a magnitude dos deslocamentos.

\subsubsection{Deslocamento Quadrático Médio}

Para determinar o MSD calculam-se os deslocamentos $\Delta x$ e $\Delta y$ para uma série respectiva de intervalos temporais $\Delta t=\delta t, 2 \delta t, 3 \delta t, \ldots$, onde $\delta t$ é o menor intervalo da série temporal, mas também pode-se calculá-lo como uma variação geométrica no tempo: $\Delta t=\delta t, 2 \delta t, 4 \delta t$, $8 \delta t, \ldots$. Temos então que:

$$
x_{i}=x\left(t_{0}+i \delta t\right),
$$


e a equação para o eixo-y é análoga. O deslocamento quadrático é a soma do deslocamento quadrado em x com o deslocamento quadrado em y, :

$$
\left(\Delta r_{i}(\Delta t)\right)^{2}=\left(\Delta x_{i}(\Delta t)\right)^{2}+\left(\Delta y_{i}(\Delta t)\right)^{2}
$$

Para os $\Delta t$ s pequenos há um maior número de MSDs do que para os $\Delta t$ s grandes (Fig. 2.6. . O MSD é obtido como a média de todos os passos correspondentes a cada $\Delta t$ :

$$
\left\langle(\Delta r(\Delta t))^{2}\right\rangle=\frac{1}{n}\left(\Delta\left(r_{1}(\Delta t)\right)^{2}+\Delta\left(r_{2}(\Delta t)\right)^{2}+\ldots\right)=\frac{1}{n} \sum_{i=1}^{n} \Delta r_{i}^{2}(\Delta t),
$$

sendo $n$ o inteiro da divisão $(N-1) \delta t / \Delta t$. O MSD é obtido realizando esse procedimento para os múltiplos $\delta t$ s. Se o movimento é difusivo o MSD é proporcional a $\Delta t$. Tem-se difusão anômala quando $\mathrm{MSD} \propto \Delta t^{\beta}$, se $\beta<1$ tem-se subdifusão, e se $\beta>1$ tem-se um comportamento superdifusivo. O movimento pode ter características intermediárias, para um comportamento restrito a uma área o MSD tende a se estabilizar em um valor [40]. O movimento subdifusivo tem a característica de ser confinado (Figura 2.7a), e o movimento superdifusivo apresenta saltos muito grandes de uma posição para outra para um mesmo intervalo de tempo (Figura 2.7b)
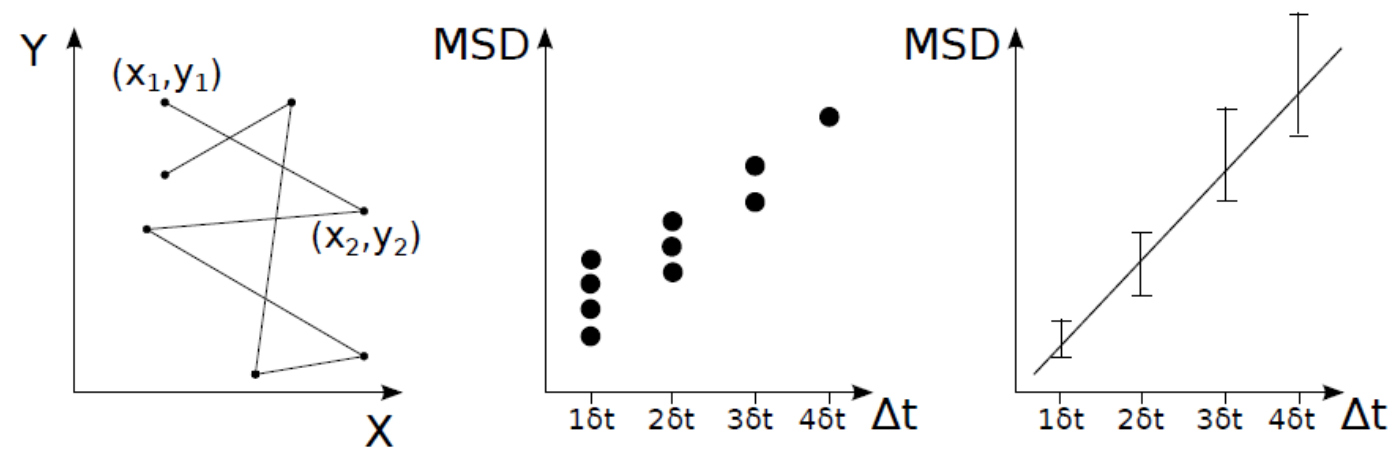

Figura 2.6: Esquema de representação do MSD. Figura retirada de [0].

\subsubsection{Magnitude dos Deslocamentos - $Z$}

A magnitude dos deslocamentos pode ser indicada por $Z$ e é calculada como:

$$
Z_{x, y}=\frac{\Delta x, y-\overline{\Delta x, y}}{S T D_{x, y}}
$$

sendo STD o desvio padrão, dado por $\operatorname{STD}_{x}=\left(1 /(n-1) \sum_{i=1}^{n}\left(\Delta x_{i}-\overline{\Delta x}\right)^{2}\right)^{1 / 2}$, analogamente para $\mathrm{STD}_{y}$. A grandeza $Z$ é calculada separadamente para os eixos x e y porque pode haver alinhamentos das células nos poços, o que levaria as microesferas a ter maior facilidade de se locomover na direção desse alinhamento do que na direção perpendicular. Separando os deslocamentos nos dois eixos é possível verificar se ocorre esse comportamento. Caso 


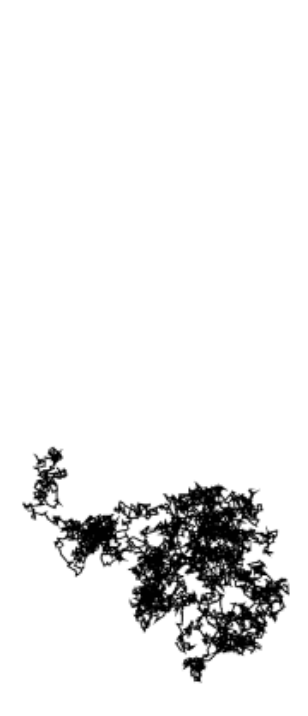

(a) caso subdifusivo

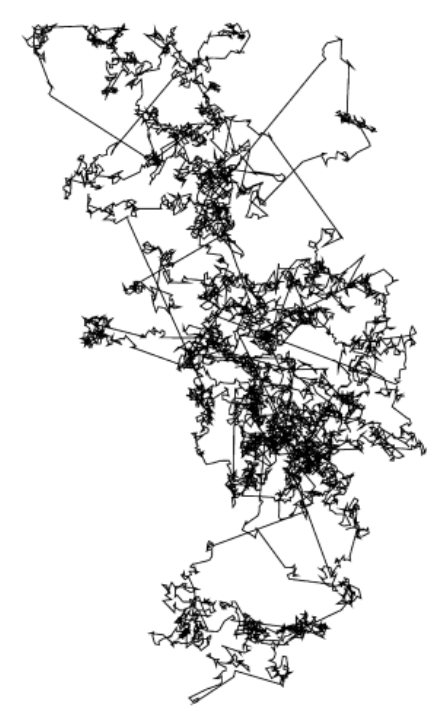

(b) caso superdifusivo

Figura 2.7: Exemplo dos tipos de difusão anômala: (a) movimento confinado, (b) movimento apresenta os saltos anômalos. Figuras retiradas de 32 .

ocorresse alinhamento das células em uma direção preferencial, mesmo que escolhessemos um sistema de referência em relação ao original, a fim de eliminar essa assimetria, a análise não seria comprometida.

\subsection{Análise de Imagens}

A identificação das microesferas e determinação da posição do centro de "massa" (CM) é feita por um programa que foi desenvolvido no $\mathrm{LabM}^{2}$ em ANSI C++. As imagens adquiridas pela câmera e armazenadas no computador podem ser interpretadas como matrizes, onde cada elemento da imagem, o pixel, é identificado como a posição $(i, j)$ na matriz, e a intensidade do pixel dada por $I(i, j)$. As imagens são gravadas em 8 bits na escala de cinza, com $I$ indo de 0 a 255 , sendo $I=0$ correspondente ao preto e $I=255$ correspondente ao branco. O CM é determinado fazendo uma média ponderada pela intensidade de cada pixel, como mostram as equações 2.6 e 2.7, sendo $\bar{X}$ e $\bar{Y}$ as coordenadas do $\mathrm{CM}$ dos eixos x e y respectivamente.

$$
\begin{gathered}
\bar{X}=\frac{\sum_{i=1}^{N} \sum_{j=1}^{N} x_{i} I(i, j)}{\sum_{i=1}^{N} \sum_{j=1}^{N} I(i, j)} \\
\bar{Y}=\frac{\sum_{i=1}^{N} \sum_{j=1}^{N} y_{i} I(i, j)}{\sum_{i=1}^{N} \sum_{j=1}^{N} I(i, j)}
\end{gathered}
$$

É possível ver pelas equações 2.6 e 2.7, que o peso para cada coordenada é dado pela intensidade do pixel, $\operatorname{logo}$ se branco tem $I=255$, e preto $I=0$, o CM ficará próximo das 
regiões mais claras da imagem, que é o que não queremos. Para isso transformamos o valor do pixel segundo a equação 2.8 :

$$
I(i, j)=255-I_{0}(i, j)
$$

a fim de que o peso maior esteja nos pixels mais escuros, ou seja, a escala de cinza fica invertida: $I=0$ passa a corresponder ao branco, e $I=255$ passa a corresponder ao preto. Nessa equação $I_{0}$ é a intensidade do pixel original, e $I$ o valor da intensidade do pixel transformada.

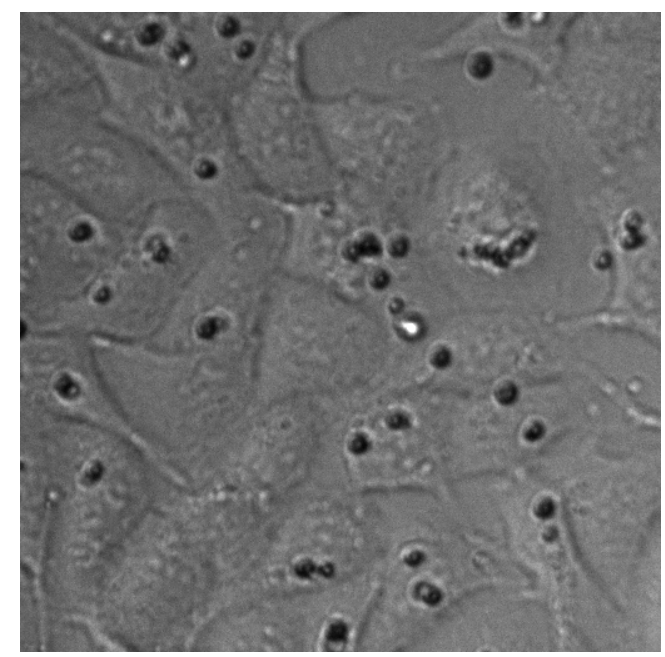

Figura 2.8: Imagem desfocada obtida pelo microscópio a fim de evidenciar mais a membrana que delimita a célula. As esferas mais escuras são as microesferas depositadadas.

As imagens adquiridas possuem um fundo acinzentado devido ao citoplasma celular, como mostra a Figura 2.8, o que interfere no cálculo do centro de massa, e como o fundo não é uniforme, havendo pontos mais claros e outros mais escuros, pode acontecer de não se calcular o CM real das esferas, o que poderia vir a prejudicar a análise da movimentação feita usualmente. Para evitar esse erro, é definido um limiar (Th) para o qual os valores de intensidade menores que ele serão transformados em branco, ou seja, terão $I(i, j)=0$.

Entretanto, esse método ainda está sujeito a erros, pois o limiar retira parte da esfera junto do fundo, o que modifica o cálculo do CM. Outro motivo é que os cálculos de $\bar{X}$ e $\bar{Y}$ dependem da coordenada do CM do frame anterior, portanto se o valor calculado é enviesado, os próximos também serão.

Em vista disso e do fato de os deslocamentos das esferas serem muito pequenos, percebese uma necessidade de quantificar o quanto se pode errar em uma medida, pois um pequeno erro na posição do centro de massa pode mudar o que se enxerga do movimento da esfera, e consequentemente a interpretação feita sobre a dinâmica destas. Com isso, a pergunta que fazemos é: qual o valor do erro da posição do pixel em uma imagem capturada pela câmera?

A câmera utilizada no $\mathrm{LabM}^{2}$ é a Andor Neo sCMOS (Fig. D.1a), refrigerada a $-40^{\circ} \mathrm{C}$, que é um dispositivo CMOS (Complementary Metal Oxide Semiconductor arrays, semi- 
condutores de óxido de metal complementares) que é similar a dispositivos CCD (Charge Coupled Device, dispositivos de carga acoplada), com a diferença de que eles contém circuitos adicionais construídos em cada pixel (Fig. D.1b). A lógica para endereçamento do pixel, leitura e conversão A/D (analog to digital, analógica-digital) são produzidas como parte de cada fileira no dispositivo. Entender como funcionam os CCDs pode ajudar a entender as fontes que produzem ruído na imagem final e assim tentar estimá-lo.

Pode-se fazer um processo de calibração para as imagens produzidas pelo CCD para obter o valor de correção do pixel das imagens finais que o programa de análise das imagens utiliza. O método é similar ao que é usado na astronomia para tratamento de imagens. Foi feito um teste com a câmera do laboratório tomando as imagens de calibração, mas por falta de tempo e pela quantidade de trabalho optou-se por estudar o erro de outra forma, que será tratada na seção adiante.

\subsection{Simulação}

\subsubsection{Introdução}

A fim de estudar o efeito do erro nas imagens adquiridas para os experimentos, cujos resultados estão no Capítulo3, foi desenvolvido um programa em Matlab pela Dra. Mariana Sacrini Ayres Ferraz, ex-aluna do LabM², que defendeu o doutorado em 2015. O estudo também se baseia no relatório de Iniciação Científica feito por uma ex-aluna do LabM $^{2}$, Amanda S. N. Freitas, que estudou o efeito do erro comparando dois programas de análise diferentes. O programa feito no Matlab simula a imagem de uma esfera ideal, e de uma esfera em uma imagem com ruído de fundo, passando-se depois o limiar, da mesma forma que o programa que processa as imagens para análise nos experimentos de difusão e OMTC procede. Foram comparadas a diferença entre o centro de "massa" na imagem ideal e na imagem com ruído depois de aplicado o limiar, ao mesmo tempo que a esfera efetua um Movimento Browniano (MB). A distância entre o CM da imagem da esfera ideal efetuando um MB e imagem com ruído aplicando o limiar é o erro. Para estudar esse erro variouse alguns parâmetros na medida, como o tamanho da esfera e valor do limiar utilizado na análise, que serão detalhados adiante.

\subsubsection{Modelo para microesfera}

O modelo usado para esfera ideal tem uma imagem cuja função é dada por [2]:

$$
I(r, w, D)=\frac{1-\tanh \left(\frac{r-D / 2}{w}\right)}{2}
$$

onde $I$ é a intensidade do pixel, $D$ é o diâmetro da esfera, $r$ é a distância de um ponto qualquer ao centro da esfera, e $w$ é um parâmetro que indica a distância na qual a esfera 
varia $76 \%$ da sua intensidade (Fig. 2.10). Representando a função dada por 2.9 em 3-D e no plano, temos as imagens em 2.9 .

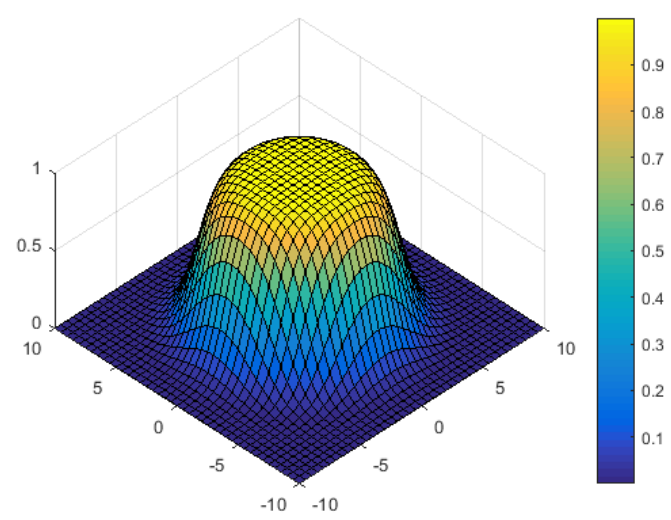

(a) representação em 3D da esfera

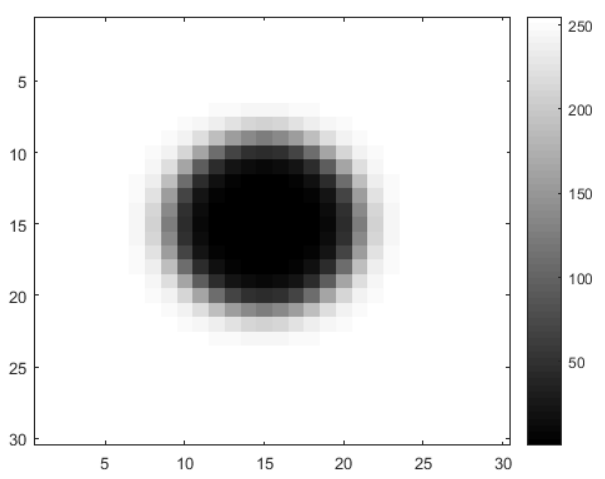

(b) representação plana da imagem das microesferas, as partes mais escuras correspondem aos pontos mais altos em (a)

Figura 2.9: Figuras geradas no Matlab com base na função dada por 2.9 com parâmetros $D=12$ e $w=1.3$.

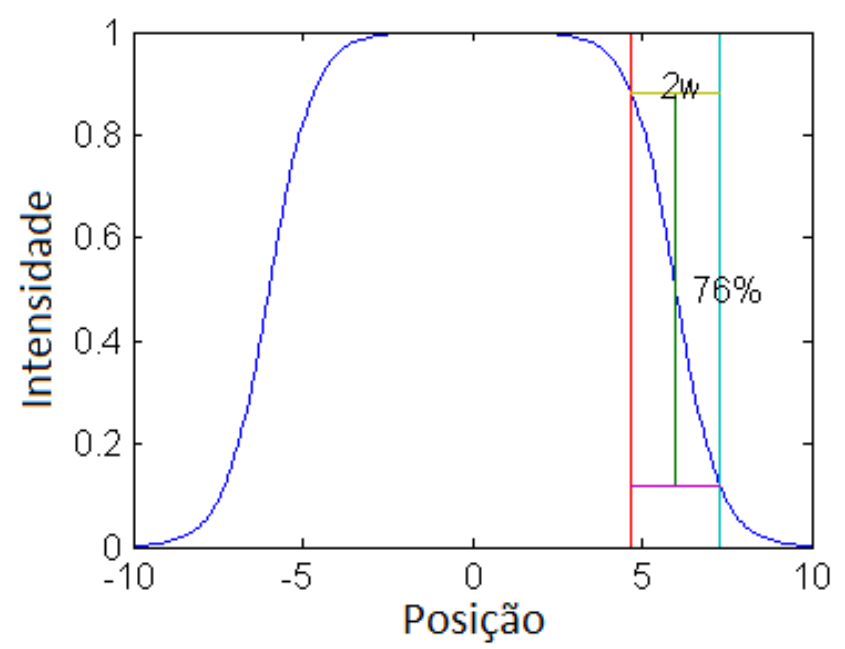

Figura 2.10: Perfil da intensidade do nível de cinza da esfera, enfatizando $w$. Figura adaptada de [2].

\subsubsection{Ruído do plano de fundo}

Foi escolhida uma imagem das microesferas na célula, do conjunto das imagens usadas na análise da posição das microesferas (Fig. 2.11) e foi analisado o ruído do plano de fundo formado pelo citoplasma, fazendo um histograma da figura dessa imagem (Fig. 2.12).

Como a maior parte da imagem é o fundo acinzentado, é possível ver no histograma que o pico representa o valor da intesidade que mais aparece na imagem. Nas imagens que o computador processa, a escala de cinza coloca o preto em 0 e branco em 255; o histograma mostra que a contagem mais alta dos pontos ocorre próximo de 180. A mesma figura mostra 


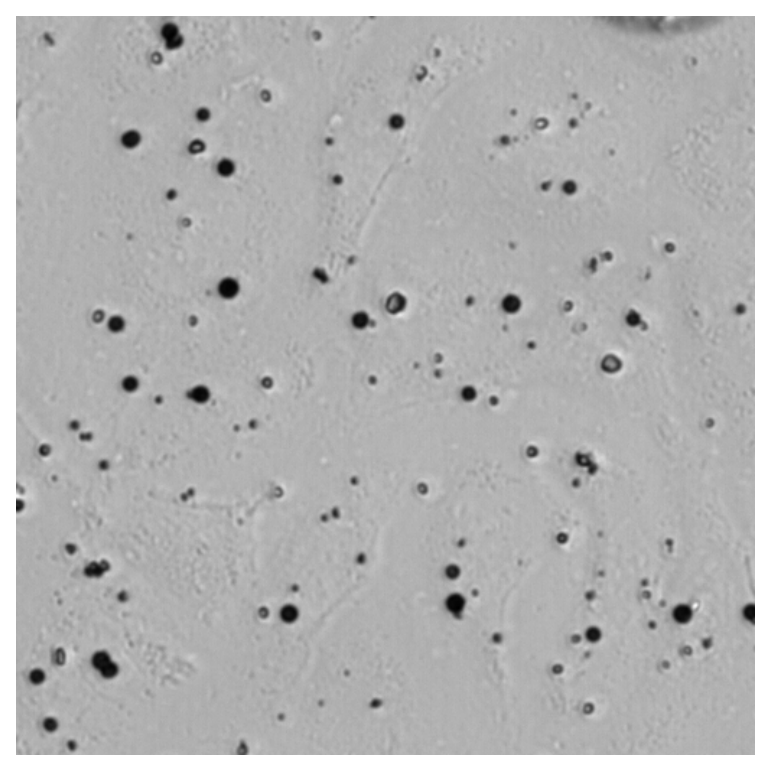

Figura 2.11: Imagem real de uma das amostras adquiridas, focando as microesferas (em preto) e o fundo acinzentado que é o tapete celular.

uma curva contínua em azul, que é uma curva gaussiana que foi ajustada aos dados. O ajuste foi feito para a função $a e^{-(x-b)^{2} / 2 c^{2}}$, com parâmetros ajustados: $a=2265.8, b=178.8$ (que é o valor médio) e $c=4.1$ (que é o desvio padrão).

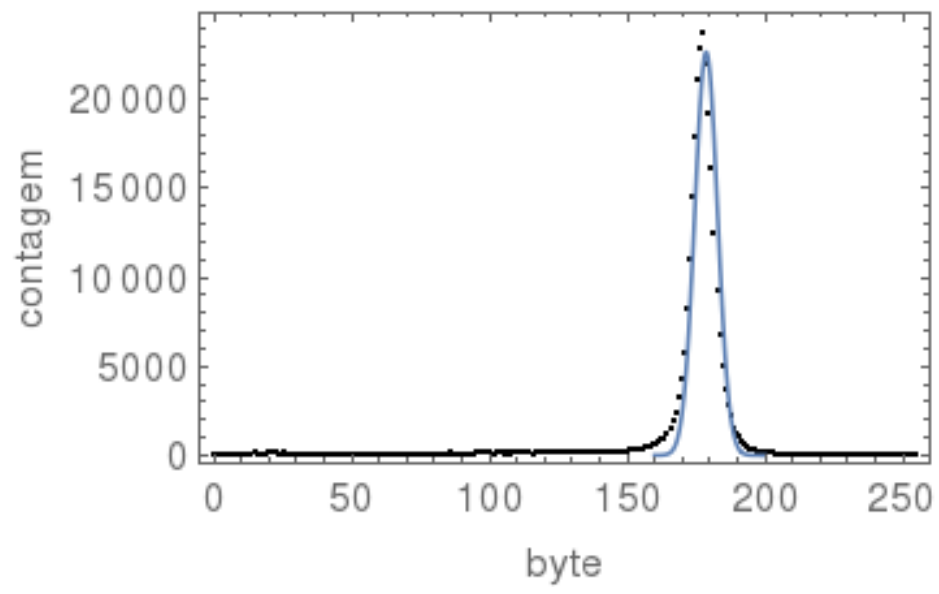

Figura 2.12: Histograma da imagem 2.11, onde é possível ver que o pico dos pontos está próximo de 180 , que é o valor que representa o cinza que ocupa a maior parte da imagem. A curva em azul é uma gaussiana ajustada aos dados, cujo valor médio é 178.7 e desvio padrão igual a 4.1 .

O programa desenvolvido no Matlab gera a imagem de uma esfera ideal (Fig. 2.13a), i.e., com fundo branco, e a partir da análise do histograma da Figura 2.12 foi gerada uma imagem idêntica à da esfera ideal, só que com o plano de fundo tendo sido gerado seguindo uma distribuição normal com média 178.7 e desvio padrão 4.1, os mesmos valores do ajuste feito para o histograma (ver Fig. 2.13b). 


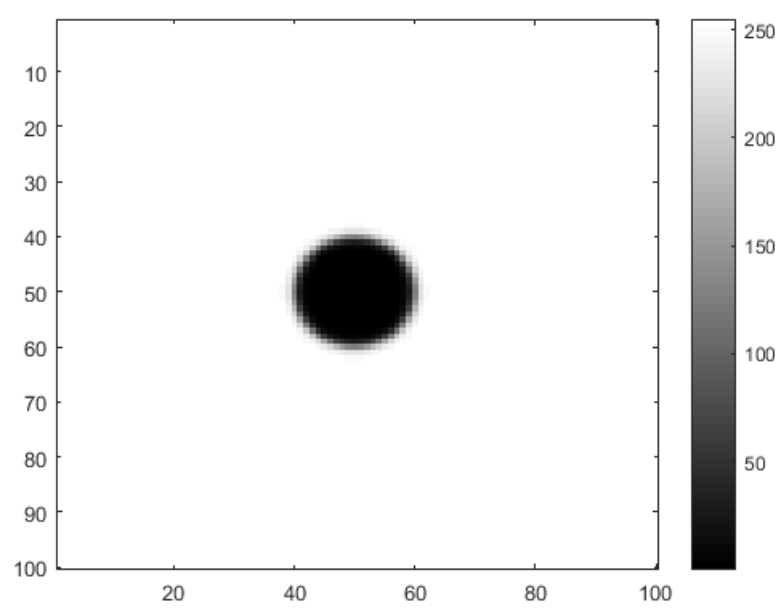

(a) imagem da esfera ideal.

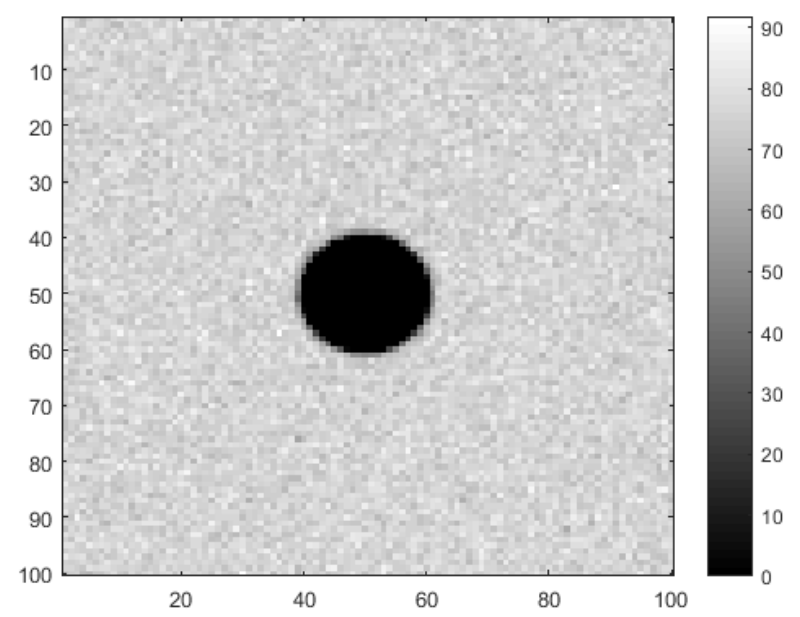

(b) imagem da esfera com ruído de fundo gerado por uma distribuição normal de média 178.7 e desvio padrão de 4.1 .

Figura 2.13: As esferas foram geradas pela função 2.9 com parâmetros $D=20$ e $w=1$.

\subsubsection{Caminhada aleatória (Random Walk)}

Como a posição da microesfera varia frame a frame, foi gerado um caminho aleatório com desvio de tamanho $d=0.0375$, ou seja, $d$ tem subunidades de pixel, e foi escolhido como posição inicial do movimento a coordenada $\left(x_{0}, y_{0}\right)=(50,50)$. A cada instante de tempo são geradas imagens da esfera com centro de massa na posição dada por esse random walk gerado. As imagens geradas tem tamanho de $100 \times 100$ pixels e $w=1$. Os passos nos eixos x e y são dados de maneira independente (Fig. 2.14a).

O caminho gerado é considerado o movimento prescrito pelo CM da esfera, e a partir de cada ponto desse caminho, gera-se a esfera com centro em cada um desses pontos, aplica-se o ruído a essa imagem e depois aplica-se o limiar, para depois calcular o centro de massa usando as equações 2.6 e 2.7 .

Para calcular o centro de massa, define-se uma região de interesse, que consiste de um quadrado de lado $L$ que contém toda a região da esfera e parte do fundo em volta dela. Um dos motivos de se definir essa região de interesse é que o programa do OMTC precisa identificar individualmente as microesferas em uma imagem que contém várias microesferas; o outro motivo é que a região de interesse, por delimitar a área em volta da esfera considera para o cálculo do CM apenas os pixels nessa região, o que diminui o efeito do ruído de fundo no cálculo. Por conta desse motivo a região de interesse $(L)$ definida tem que ter tamanho pouco maior que o diâmetro da esfera criada, e centro na mesma coordenada do CM da esfera, depois de passado o limiar (Fig. 2.14b). A cada nova iteração o centro de massa é calculado contabilizando apenas os pixels dentro dessa região de interesse. Nas simulações feitas, cujos resultados são mostrados adiante serão definidos os valores utilizados para o diâmetro $(D)$ e região de interesse $(L)$. 


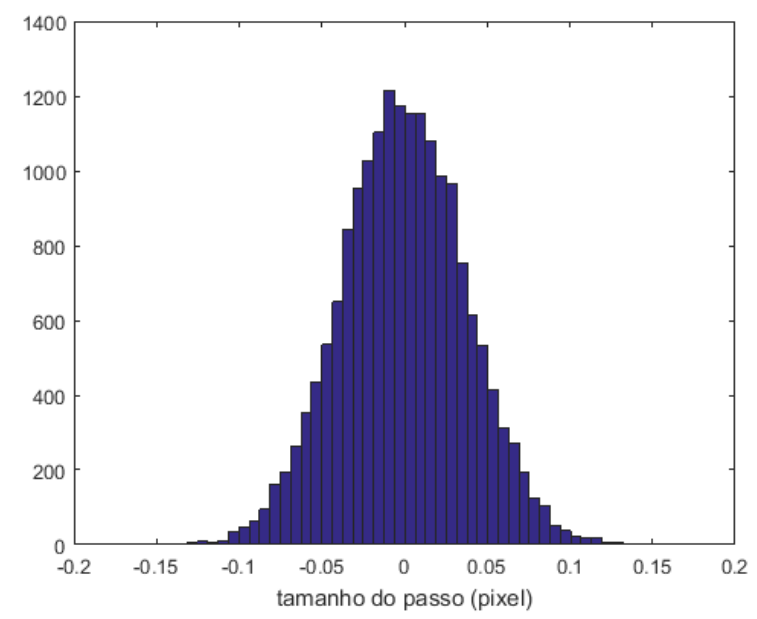

(a)

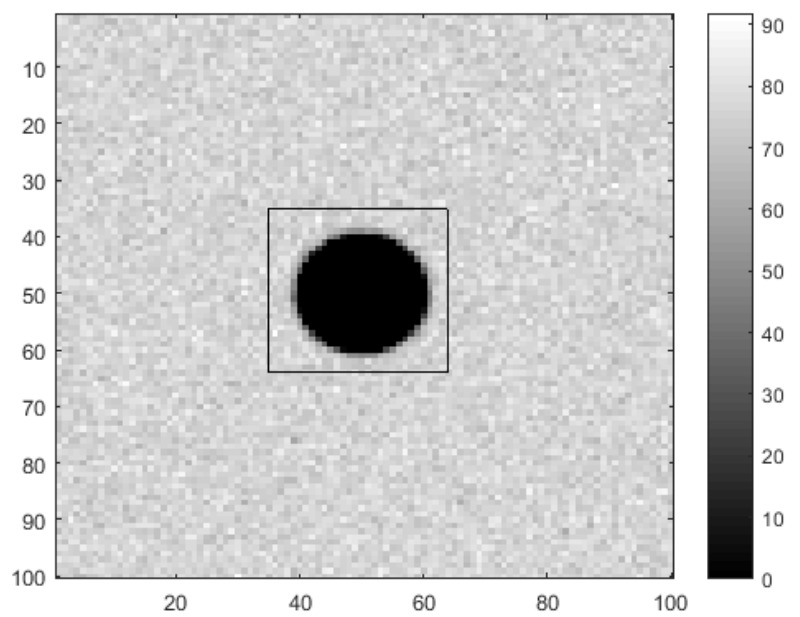

(b)

Figura 2.14: (a) Histograma dos passos da caminhada aleatória feita pela esfera. Os passos foram gerados com média 0 e desvio padrão $\mathrm{d}=0.0375$, para um caminho aleatório com 9000 passos, tanto para $\mathrm{o}$ eixo $\mathrm{x}$ quanto para o eixo y. (b) Imagem da esfera com ruído de fundo e região de interesse em volta da esfera;

Define-se o erro como a distância entre a coordenada descrita pelo caminho aleatório: $\mathrm{CM}_{\text {prescrito }}=\left(x_{o}, y_{o}\right)$, e a coordenada calculada depois de aplicado ruído e aplicado o limiar: $\mathrm{CM}_{\text {encontrado }}=\left(x_{e}, y_{e}\right)$, que é o mesmo erro que queríamos determinar originalmente, de quanto o programa que calcula o CM das esferas pode errar em uma medida. Então, matematicamente:

$$
\text { Erro }=\sqrt{\left(\mathrm{x}_{\mathrm{e}}-\mathrm{x}_{\mathrm{o}}\right)^{2}+\left(\mathrm{y}_{\mathrm{e}}-\mathrm{y}_{\mathrm{o}}\right)^{2}}
$$

\subsection{Resultados e análise}

\subsubsection{Escolhendo parâmetros fixos}

Fazendo uma simulação para um MB com 9000 passos, $D=20, w=1, L=30$ (tamanho da região de interesse) e limiar $(T h)=100$, com a esfera iniciando o movimento na posição $(50,50)$, em uma imagem de 100 x 100 pixels, temos como resultado o caminho descrito na Figura 2.15a, onde o caminho em azul representa o MB descrito por uma esfera ideal (caminho prescrito), e o caminho em vermelho é o caminho da esfera não ideal (caminho encontrado). A figura 2.15b mostra a esfera na posição final do MB descrito, coordenada (47.601,43.392), depois de aplicado limiar.

Fazendo a distribuição do erro, definido na Equação 2.10, obtemos como resultado para o caminho dessa simulação o histograma da Figura 2.16. Os valores de média e desvio padrão dessa distribuição são respectivamente 0.0314 e 0.0153. O histograma mostra uma distribuição assimétrica com uma cauda mais alongada para direita. A média representa o erro médio no cálculo do caminho feito pela esfera na figural ideal e na figura com ruído. 


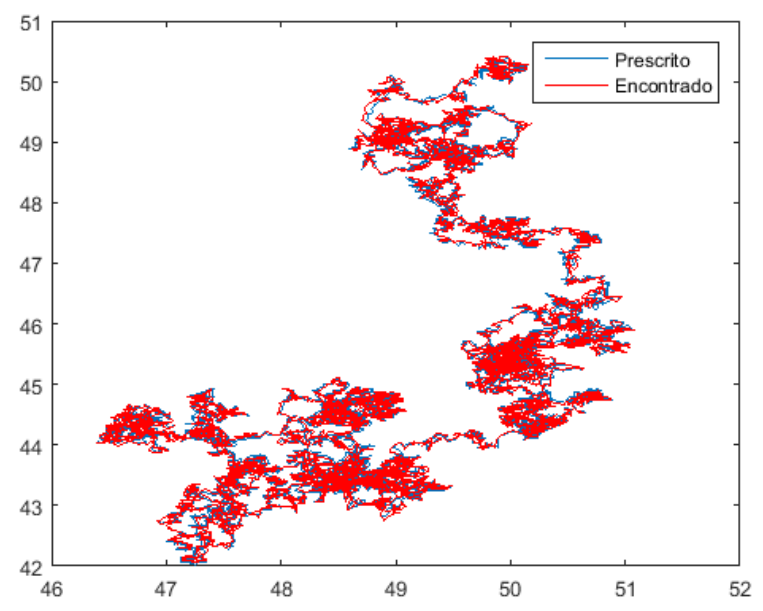

(a)

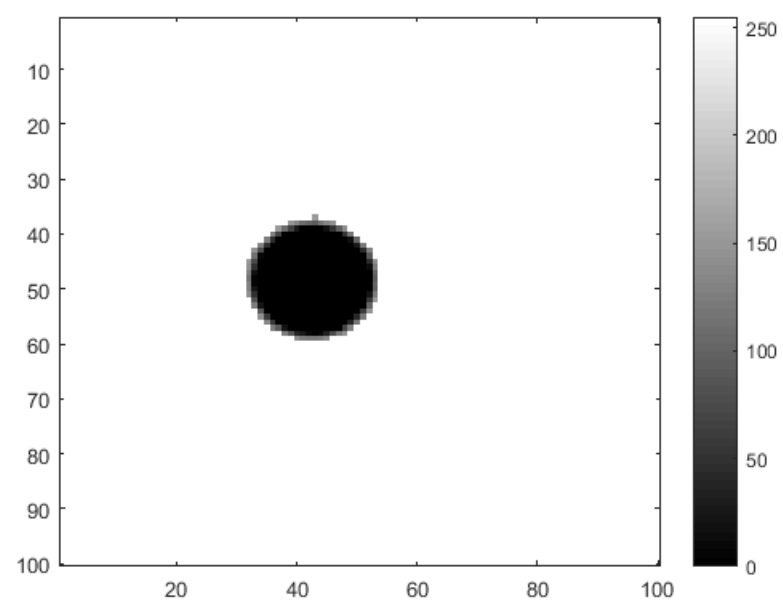

(b)

Figura 2.15: (a) Exemplo de comparação do MB descrito pela esfera ideal (caminho prescrito), e MB da esfera não ideal (caminho encontrado); (b) Imagem da esfera com limiar aplicado na a posição final $(47.601,43.392)$ do caminho feito em (a) com $T h=100, D=20$ e $L=30$.

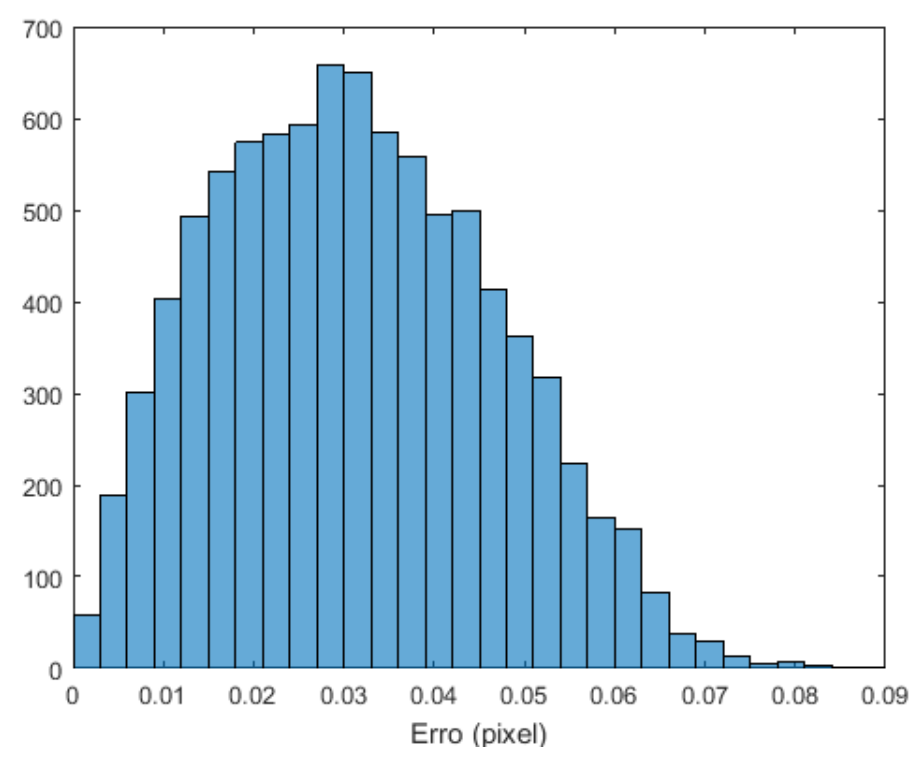

Figura 2.16: Histograma da distribuição do erro da simulação de $2.15 \mathrm{a}$. Média $=0.0314$; desvio padrão $=$ 0.0153 .

\subsubsection{Variação do erro com o diâmetro}

Foi avaliado o efeito do erro para diferentes valores de diâmetro $(D)$ e limar $(T h)$. Os valores de diâmetro escolhidos tem a ver com o tamanho das microesferas e a magnificação usada experimentalmente. As microesferas usadas tem diâmetro aproximado de $3.58 \mu \mathrm{m}$ (ver Apêndice B) e a para as magnificações usadas neste trabalho de 10 x e 20 x, a relação é de $0.648 \mu \mathrm{m} /$ pixel e $0.324 \mu \mathrm{m} /$ pixel respectivamente (ver Apêndice C). É possível ir até $63 \mathrm{x}$, cuja relação é de $0.103 \mu \mathrm{m} /$ pixel. Para essas relações, o diâmetro da microesfera nas imagens pode ter um alcance que varia entre 5 pixels e 35 pixels. Então foi escolhido trabalhar com $D$ nessa faixa de valores. Experimentalmente, é comum usar um limiar alto, por volta de 
180 na escala de cinza, podendo ser escolhido entre 0 e 255. Os limiares foram variados de $15 \%$ a $80 \%$ de 255 , sendo o branco considerado no 0 e preto no 255 .

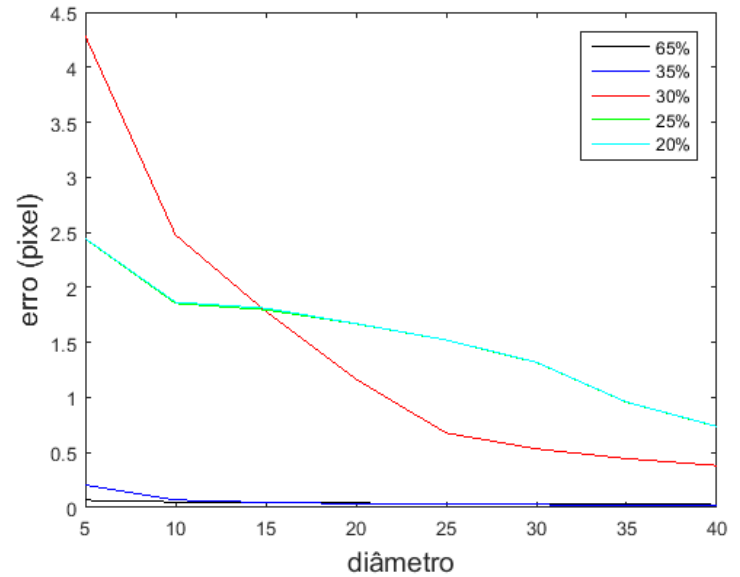

(a) diferentes porcentagens do limiar aplicado

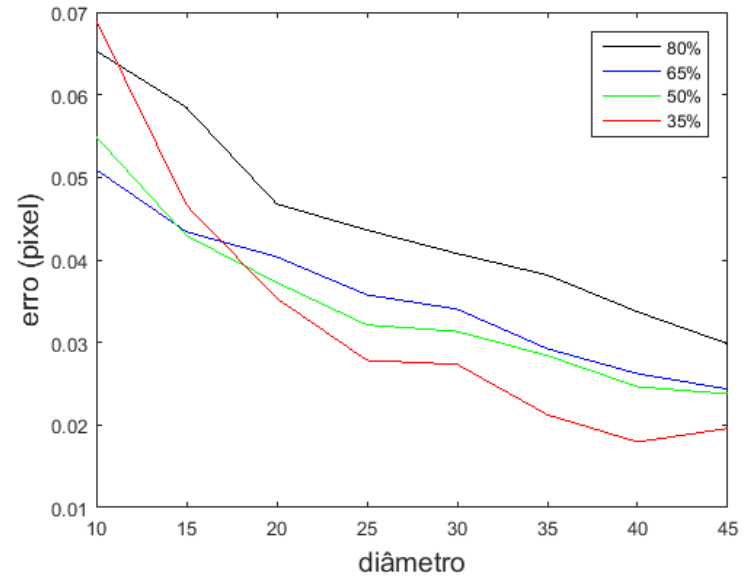

(b) altas porcentagens do limiar aplicado

Figura 2.17: Gráfico do erro versus diâmetro da esfera para os diferentes limiares. As unidades estão em pixels tanto o diâmetro quanto o erro.

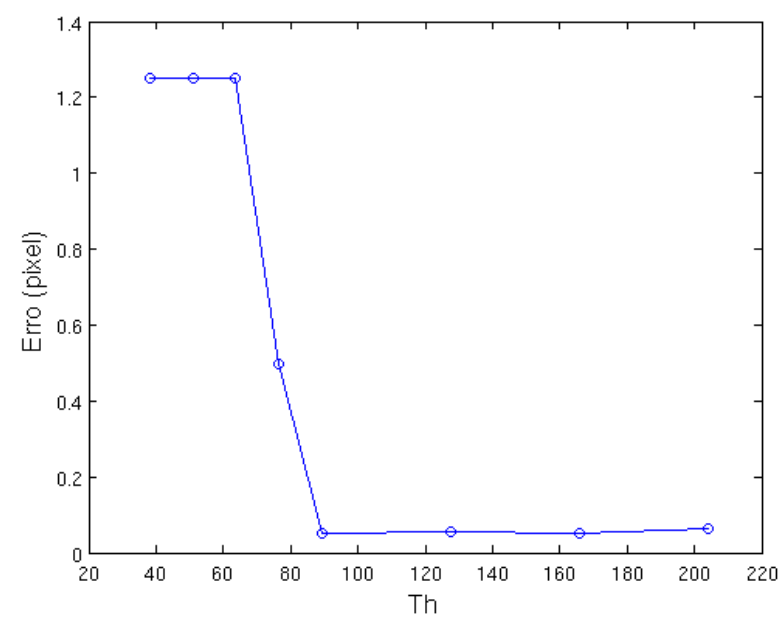

Figura 2.18: Gráfico do erro versus Th para o diâmetro fixo $D=10, L=20$, e $T h$ na escala de cinza de 0 a 255 , com preto no 255 e branco no 0 .

É possível simular a variação do erro com o diâmetro escolhido da esfera para diferentes limiares. Na configuração de $w=1, L=60$ e 1000 MB de 9000 passos cada, o resultado do erro é dado pela Figura 2.17. Essas figuras mostram altas e baixas porcentagens de Th, com 0 branco e 255 no preto. Então, $80 \%$ de $T h$ significa que pixels com nível de cinza abaixo de 204 serão tornados brancos, ou seja, terão valor 0. A Figura 2.17a foi feita com altas e baixas porcentagens de $T h$, e obteve-se que abaixo de $35 \%$ de $T h$ (ou seja, pixels na escala de cinza abaixo de 89 serão tornados brancos), o erro fica maior que 1 pixel. Para altas porcentagens de $T h$ (acima ou igual a 35\% de $T h$ ) o erro fica menor que 1 pixel de distância (Fig. 2.17b) para todos os diâmetros entre 5 e 45 pixels, sendo que para um diâmetro maior que 20 pixels 
o erro cai com o limiar, desde que ele ainda seja maior que $35 \%$ de $T h$. A conclusão que se pode tirar é que trabalhar com maior valor do limiar diminui o erro no cálculo do CM, o que já era esperado, pois quando os pixels são transformados em branco, eles passam a ter peso nulo no cálculo do CM, logo as bordas da esfera ficam mais definidas.

Com o gráfico da Figura 2.18 vê-se que o erro é mínimo para um Th próximo de 90 na escala de cinza, i.e., aproximadamente $35 \%$ de 255 , com 0 no branco e 255 no preto.

Para todos os valores de $D$ escolhidos, a região de interesse $(L)$ escolhida é maior que $D$. Se é escolhido um valor de $L$ menor que $D$, o cálculo do erro perde o sentido pois ele passa a considerar apenas uma parte da esfera, e então o CM calculado fica enviesado.

\subsubsection{Variação do ruído com o tempo}

Experimentalmente nota-se que a quantidade de luz incidindo na amostra é variável, pois na sequência de imagens obtidas algumas são mais claras e outras mais escuras. Foi feita uma simulação para avaliar o efeito do ruído com o tempo; a simulação olha para o valor de cada pixel em nível de cinza em uma sequência de imagens.

Foi escolhida uma sequência de 6000 imagens (corresponde a aproximadamente 40 segundos de observação) tomadas a 145 fps, com um tamanho de 200 x 200 pixels, a mesma sequência da imagem mostrada em 2.11, mas escolhendo um tamanho menor e menos imagens devido a capacidade de processamento computacional.

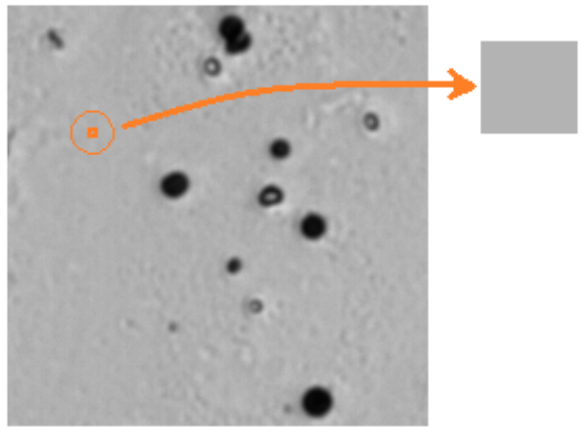

(a)

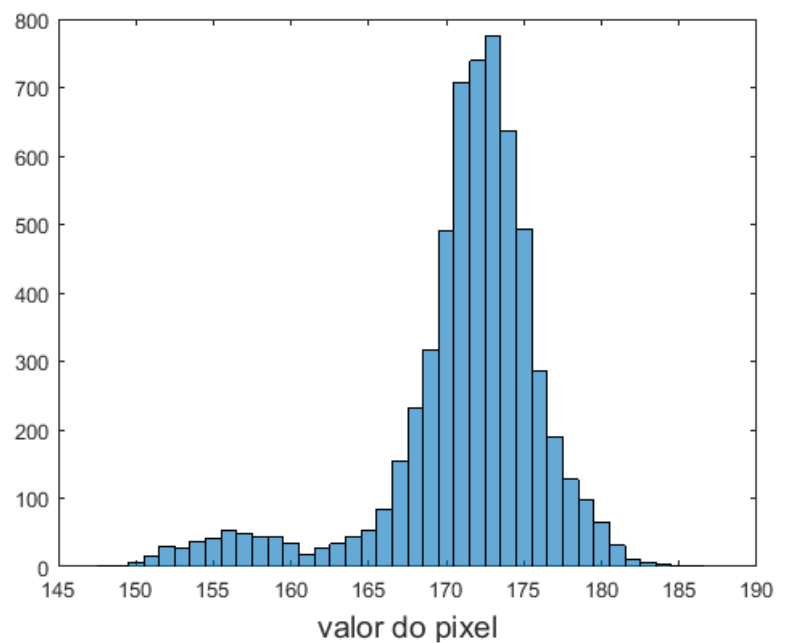

(b)

Figura 2.19: (a) Primeira imagem da sequência de imagens utilizada para análise temporal, mostrando a intensidade inicial do pixel desta posição. (b) Histograma da distribuição temporal (em 6000 imagens) do ponto expecificado em (a).

A Figura 2.19a mostra uma região da imagem 2.11 da qual foi feita a simulação. Como o padrão da imagem é parecido com o padrão da imagem original, usar um tamanho menor não acarreta perda na análise. A Figura $2.19 \mathrm{~b}$ mostra a distribuição do valor do pixel indicada no centro do círculo pela figura 2.19a. Para os outros pixels a forma da distribuição é similar; a 
distribuição indica que na maior parte do tempo a amostra foi bem iluminada: um pico mais alto no valor de pixel mais alto, e por pouco tempo estava mais escuro: um pico bem mais baixo em um valor de pixel mais baixo. No processamento das imagens o computador coloca de imediato preto no 0 , por isso nessa distribuição o valor mais alto da intensidade do pixel corresponde a uma cor mais clara. A coordenada em particular da figura 2.19b é um pixel do fundo da imagem, mas a distribuição é similar para a borda ou centro das microesferas, com a diferença de que a distribuição toda é deslocada, pois nos pixels da borda e centro das microesferas o valor da intensidade é mais escuro.

\subsubsection{Variação do erro com ruído variável}

O fator que mais influencia na determinação do CM das microesferas é a qualidade da imagem adquirida experimentalmente. Uma imagem que pode ser considerada boa para a análise do CM é aquela em que as bordas das esferas são bem definidas e o fundo é bem mais claro que as microesferas. Um fundo muito escuro prejudica na identicação do CM da esfera. Queremos simular o efeito do erro que pode ser cometido no cálculo do CM da microesfera usando um ruído variável com o tempo. A variação do ruído foi escolhida variando a média, indo de valores mais claros até mais escuros, porém com um desvio padrão constante, escolhido a partir da distribuição dada para a Figura 2.11, cujo valor é igual a 4.1 .

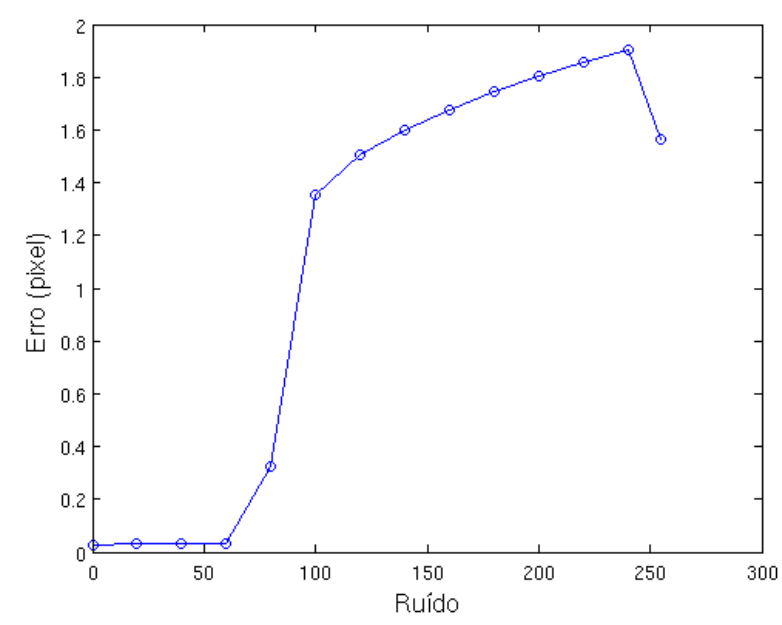

Figura 2.20: Erro calculado vs. ruído variável.

Na simulação o ruído é variado em cada passo, e a cada MB, sendo gerado como uma distribuição normal com uma média variando e escolhida, que é o eixo x da Figura 2.20, e desvio constante igual a 4.1. O resultado é dado pela Figura 2.20. Para essa simulação foram escolhidos como parâmetros $D=10, w=1, L=20$ e $T h=30 \%$, com 20 MB de 9000 passos cada.

A Figura 2.20 mostra que mesmo para um valor de limiar baixo, quanto maior o nível de escuro do fundo, maior o erro cometido no cálculo do CM. 


\section{Capítulo}

\section{Resultados e Discussão}

Foram calculados $Z$, o MSD e a inclinação $\beta$ do MSD na escala logarítmica para todas as séries de dados da tabela 3.1 . Como $\mathrm{MSD} \propto \Delta t^{\beta}$, então:

$$
\beta=\frac{\partial \ln (\mathrm{MSD})}{\partial \ln (\Delta \mathrm{t})}
$$

Podemos resumir as informações dos experimentos realizados na tabela 3.1 .

As figuras em 3.1 a seguir mostram o histograma dos $Z$ ( $Z$ x e $Z$ y) e os gráficos de MSD em função do tempo para os quatro Grupos Experimentais da tabela 3.1. Os parâmetros da gaussiana ajustada no histograma dos $Z$ s e das retas ajustadas nos gráficos dos MSDs estão na tabela 3.2 .

Tabela 3.2: Parâmetros ajustados para os dados nos quatro experimentos da tabela $3.1 \mu$ denota a média e $\sigma$ o desvio padrão.

\begin{tabular}{ccccccc}
\hline Grupo Experimental & microesferas & frequência & $\mu$ gaussiana & $\sigma$ gaussiana & ajuste reta verde & ajuste reta vermelha \\
\hline$\# 1$ & 187 & 145 & $1.88 \times 10^{-18}$ & 0.999 & $(8.01 \pm 0.08)+(0.17 \pm 0.02) \mathrm{x}$ & $(8.57 \pm 0.05)+(0.97 \pm 0.03) \mathrm{x}$ \\
$\# 2$ & 884 & 145 & $-1.07 \times 10^{-18}$ & 0.999 & $(6.81 \pm 0.04)+(0.11 \pm 0.01) \mathrm{x}$ & $(6.29 \pm 0.04)+(1.34 \pm 0.01) \mathrm{x}$ \\
$\# 3$ & 383 & 145 & $-9.41 \times 10^{-19}$ & 0.999 & $(8.59 \pm 0.07)+(0.36 \pm 0.02) \mathrm{x}$ & $(7.55 \pm 0.22)+(1.27 \pm 0.07) \mathrm{x}$ \\
$\# 4$ & 54 & 200 & $4.44 \times 10^{-18}$ & 0.999 & $(8.25 \pm 0.01)+(0.02 \pm 0.01) \mathrm{x}$ & $(6.60 \pm 0.52)+(1.14 \pm 0.19) \mathrm{x}$ \\
\hline
\end{tabular}

Tabela 3.1: Experimentos com RASM apresentados neste trabalho.

\begin{tabular}{ccccccc}
\hline Grupo Experimental & pocinhos & amostras & microesferas & imagens & frequência (fps) & magnificação \\
\hline$\# 1$ & 5 & 9 & 187 & 8200 & 145 & $20 \mathrm{x}$ \\
$\# 2$ & 6 & 20 & 884 & 8200 & 145 & $20 \mathrm{x}$ \\
$\# 3$ & 3 & 4 & 383 & 8200 & 145 & $10 \mathrm{x}$ \\
$\# 4$ & 2 & 5 & 54 & 8200 & 200 & $10 \mathrm{x}$ \\
\hline
\end{tabular}




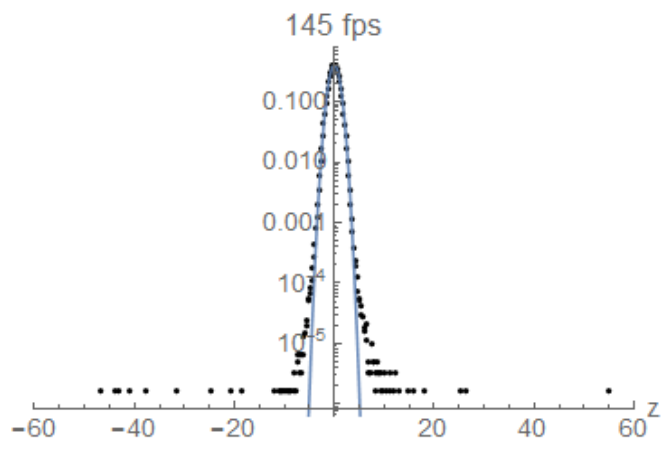

(a) Grupo Experimental \#1

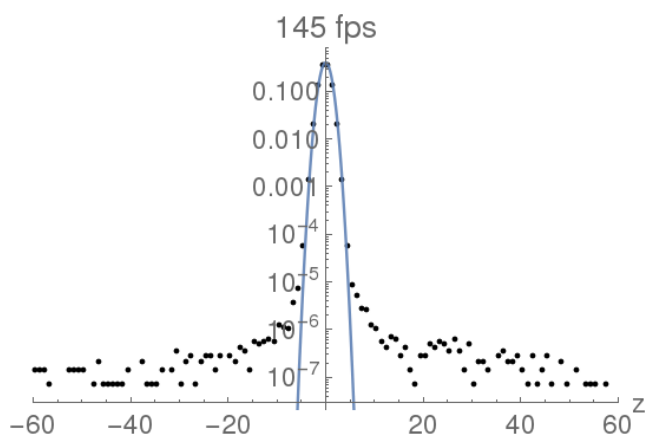

(c) Grupo Experimental \#2

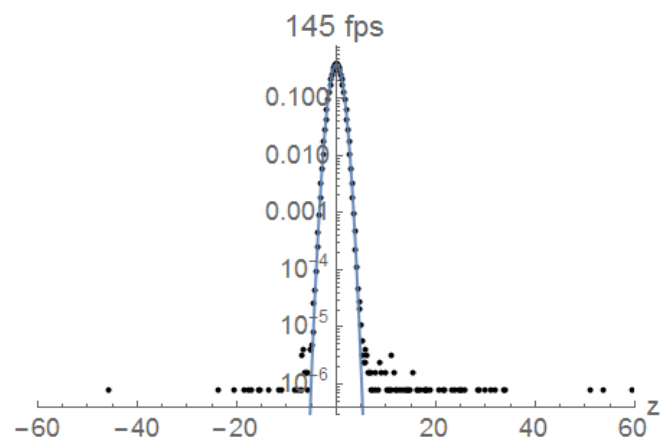

(e) Grupo Experimental \#3

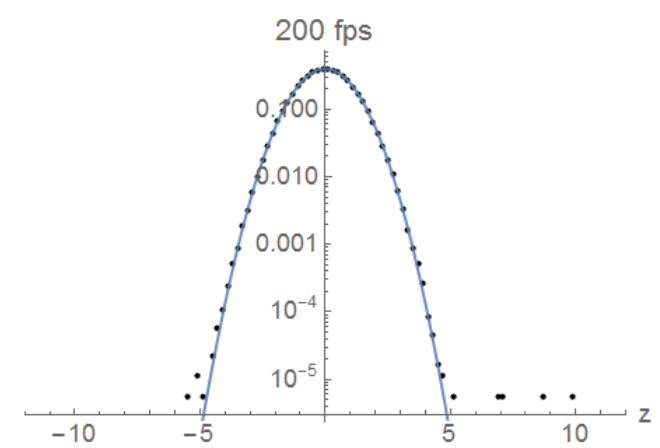

(g) Grupo Experimental \#4

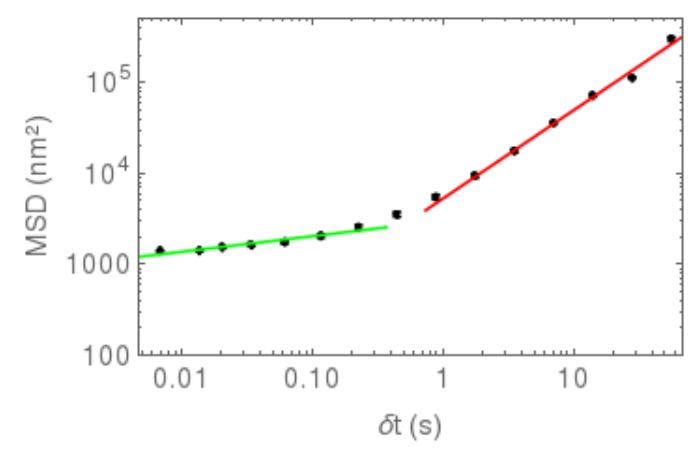

(b) ajuste para os sete primeiros pontos e seis últimos pontos

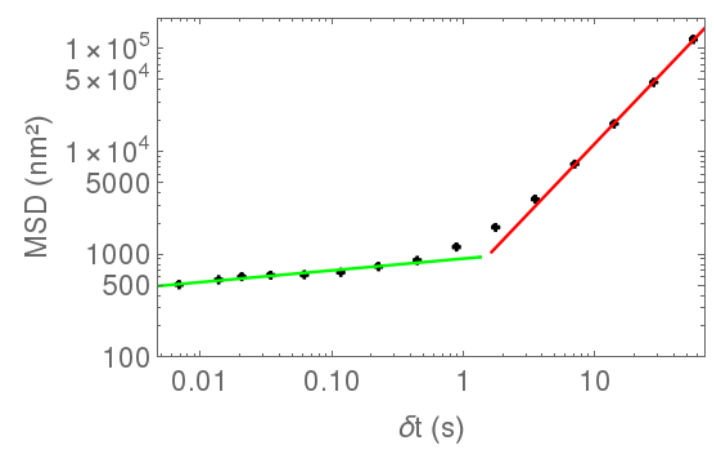

(d) ajuste para os oito primeiros pontos e quatro últimos pontos

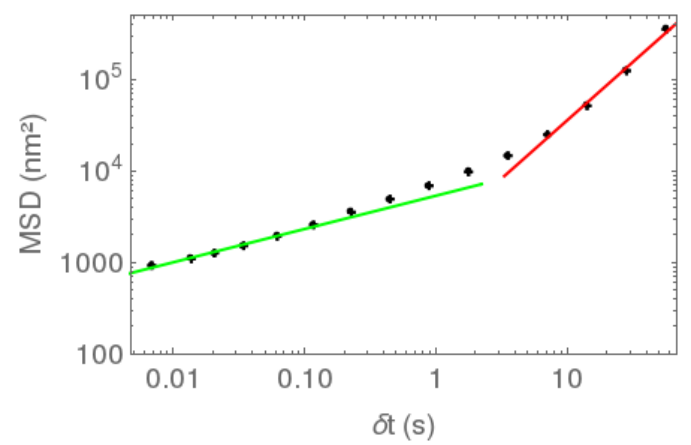

(f) ajuste para os seis primeiros pontos e quatro últimos pontos

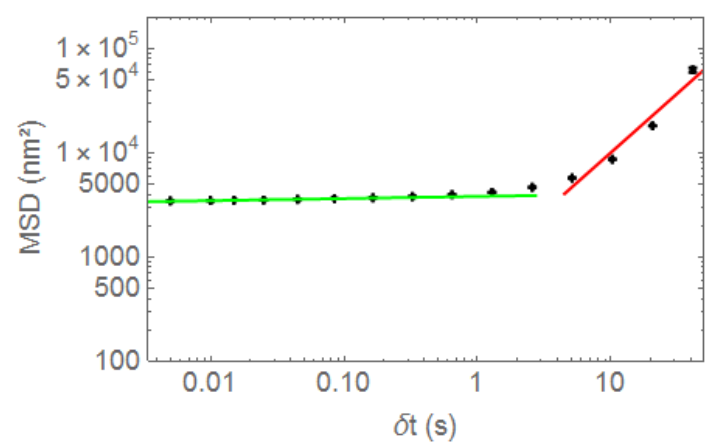

(h) ajuste para os seis primeiros pontos e quatro últimos pontos

Figura 3.1: Histogramas dos $Z$ s para os Grupos Experimentais realizados; em (a), (c), (e) e (g) a curva azul é uma gaussiana ajustada para os dados e os bins dos histogramas tem tamanho 0.2. As figuras (b), (d), (f) e (h) mostram os MSDS para os dados das figuras à esquerda. As curvas verde e vermelho nos gráficos do MSD são os ajustes respectivos à subdifusão e superdifusão. 
As figuras de 3.1a, 3.1c, 3.1e e 3.1g mostram que os dados começam a descolar da gaussiana ajustada a partir de $|Z|>3$. O citoplasma das células tem movimentação que se deve a movimentação difusiva térmica e outra parte que é devida a fatores ativos, no caso os dados que estão mais no centro da gaussiana correspondem a essa movimentação térmica, e movimentação ativa é que faz os dados terem as caudas alongadas.

As retas ajustadas para os MSD em $3.1 \mathrm{~b}, 3.1 \mathrm{~d}$, 3.1f e $3.1 \mathrm{~h}$ mostram para os primeiros $\delta$ s um comportamento subdifusivo $(\beta<1)$, sendo $\beta$ o coeficiente angular das retas ajustadas. Para os $\delta$ s maiores (o segundo ajuste em cada gráfico) o regime é superdifusivo $(\beta>1)$.

A novidade que conseguimos introduzir diz respeito ao primeiro ponto no gráfico dos MSDs. Com a introdução do microcontrolador fazendo trigger da câmera, foi possível aumentar a precisão temporal com a qual a câmera tira as fotos, e dessa forma conseguimos aumentar a frequência da captura de imagens, chegando a valores que não eram alcançados anteriormente na literatura. Como D. Stamenović argumenta em [45] é possível que haja três regimes de comportamento diferentes dentro da célula, a depender da escala de tempo (Fig. 3.2). Um dos regimes que o artigo fala é que para tempos menores que $0.01 \mathrm{~s}$ tería-se comportamento superdifusivo, mostrando que nessa escala de tempo os eventos que ocorrem estão na rede de actina. Com a câmera do laboratório foi possível chegar a um tempo menor, aumentando a resolução temporal em cerca de $10 \mathrm{x}$ as medidas usuais da literatura. O que foi observado nos experimentos é que nosso primeiro ponto experimental segue a tendência dos pontos seguintes, i.e., não há uma angulação maior nos gráficos do MSD que poderia sugerir uma mudança de comportamento do regime. Mais experimentos em frequências maiores são necessários para detalhar melhor o que acontece nessa escala de tempo.

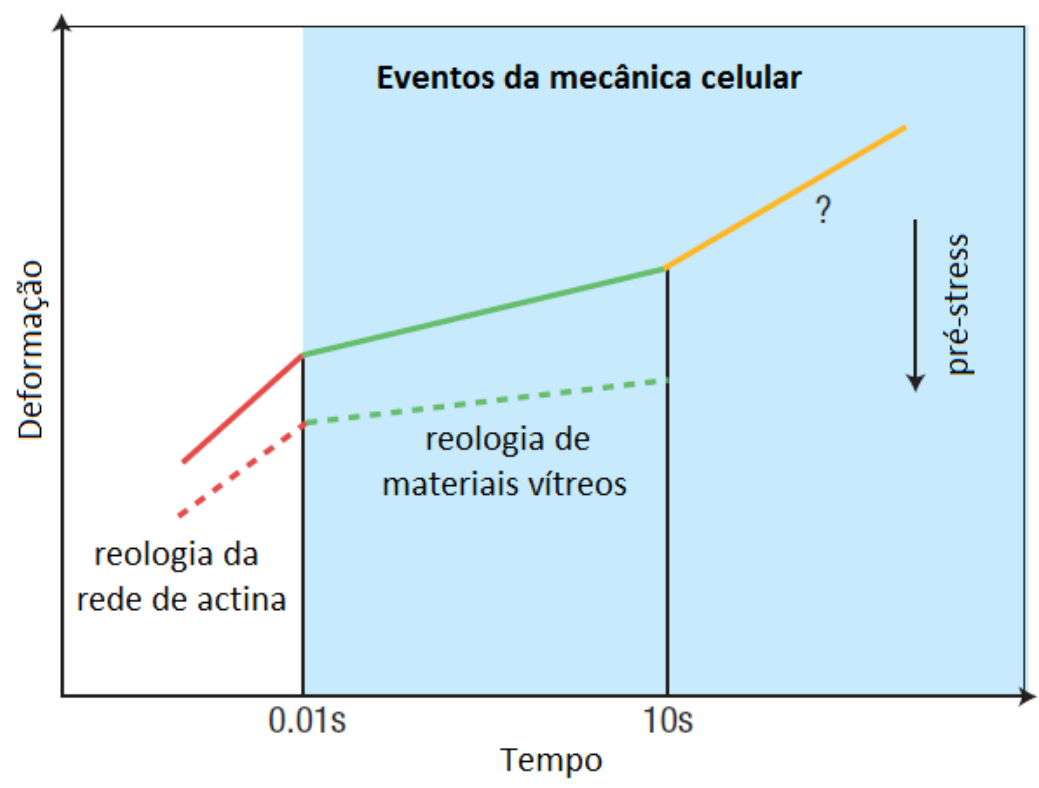

Figura 3.2: Representação dos regimes dentro da célula nas escalas de tempo. Figura adpatada de [45]. 


\subsubsection{Investigando difusão anômala}

Para os quatro Grupos Experimentais foram feitos histogramas variando a frequência. A frequência máxima de aquisição é apresentada na tabela 3.1. No cálculo dos $Z$ s para frequência máxima, o intervalo de tempo mínimo entre cada posição é 1/(valor da frequência), portanto aumentado o valor do intervalo de tempo, o valor da frequência será menor.

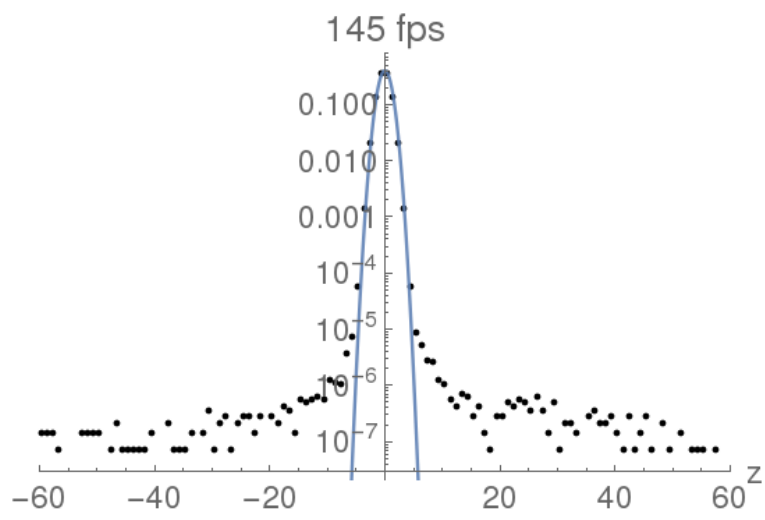

(a)

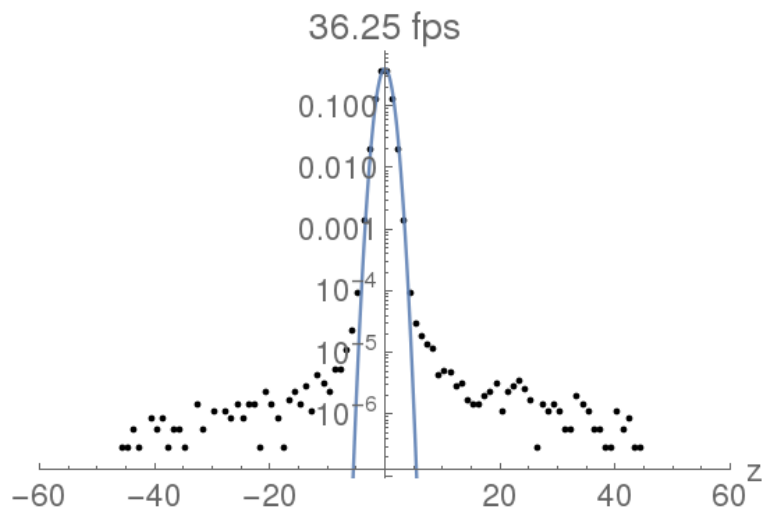

(c)

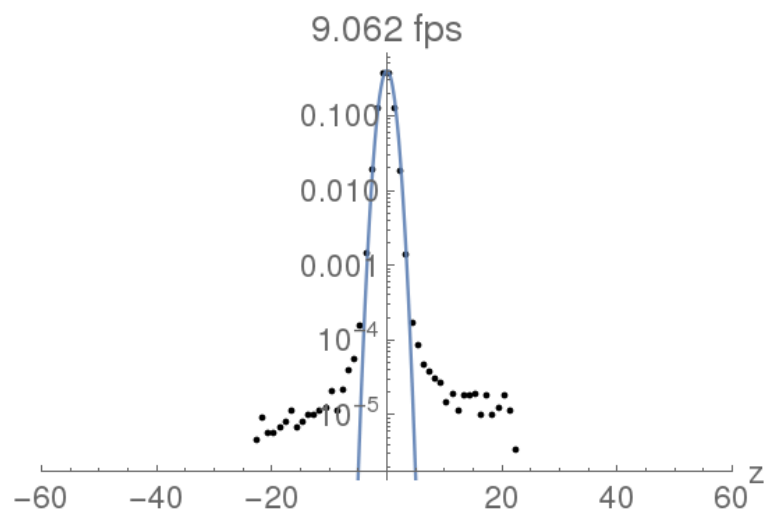

(e)

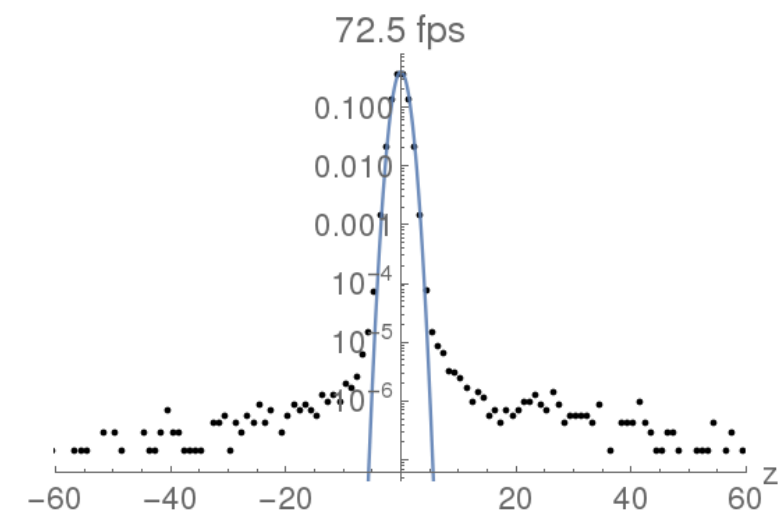

(b)

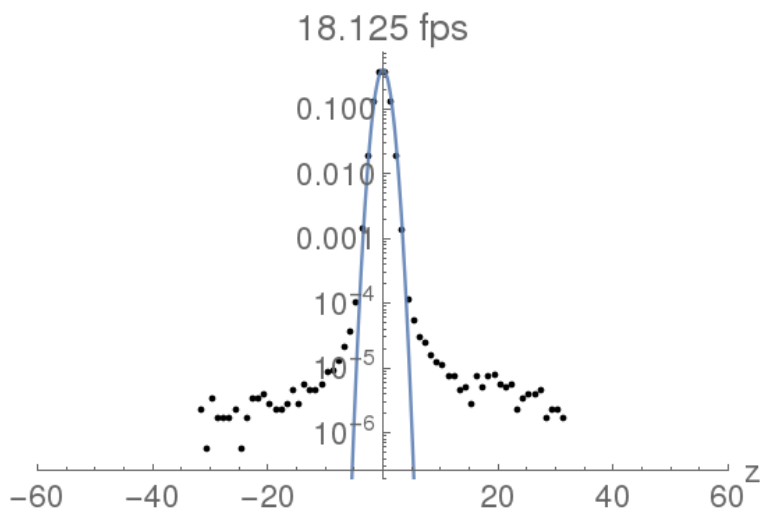

(d)

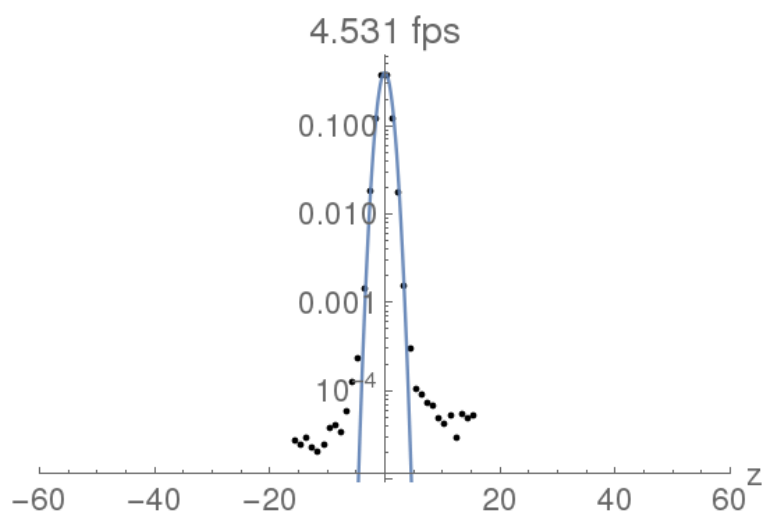

(f)

Figura 3.3: Histogramas para as diferentes frequências mostrando as caudas para o Grupo Experimental \#2. O bin utilizado tem tamanho igual a 1. Os histogramas foram graficados a fim de eixos permanecerem na mesma escala. 
Nessa seção apresentamos os histogramas variando a frequência apenas para o Grupo Experimental \#2, visto que o comportamento dos histogramas para os outros experimentos é similar. A escolha por apresentar os histogramas do Grupo Experimental \#2 deve-se a este ser o experimento com maior número de microesferas. Os histogramas são apresentados na Figura 3.3, mantendo os eixos na mesma escala a fim de comparação.

O arquivo de texto obtido após análise das imagens contém o valor de posição para cada microesfera em cada intervalo de tempo; então para graficarmos em frequências menores, ao invés de olharmos todas as posições, olhamos as posições pulando algumas mas de maneira uniforme, o que é equivalente a diminuir o valor da frequência. Escolhendo metade dos valores de posição do arquivo de texto gerado, temos metade do valor da frequência, e assim pode-se ir reduzindo o número de posições e diminuindo consequentemente o valor da frequência. Na prática equivale a estarmos observando a posição das microesferas em uma janela de tempo maior.

Foram feitos os histogramas para os $Z \mathrm{~s}$ em diferentes frequências (sempre diminuindo pela metade o valor anterior) para todos os experimentos, e o que se observa é que a cauda distanciando da gaussiana permanece em todas as frequências, o que é um indicativo que o fenômeno da difusão anômala é livre de escala, que é uma característica apresentada por materiais vítreos moles (softy glassy materials, SGM), presente também nos trabalhos [9, 11, 34, 45]. Essa característica fica melhor evidenciada no gráfico da Figura 3.4, que é uma representação em log-log da cauda do histograma, que será discutida mais adiante.

Outra característica observada na Figura 3.3 é que com a diminuição da frequência, a extensão das caudas fica menor, o que é um indicativo de que nas frequências mais altas estamos chegando na ordem de grandeza do tempo relativa a esses eventos anômalos.

Observa-se que os histogramas de frequências menores, por conter menos pontos, apresentam uma cauda mais evidenciada: é possível representar esses pontos em um gráfico log-log e o comportamento destes na região direita do gráfico se apresenta na forma de lei de potência, o que corresponde aos pontos que se descolam da gaussiana. Para todos os experimentos foram escolhidos os histogramas cujas frequências melhor evidenciavam a cauda, e foram feitos gráficos representados em log-log desses conjuntos de dados e ajustada uma reta em cada um deles. O Grupo Experimental \#2, por exemplo, produziu o resultado da Figura 3.4 para o histograma de frequência 145 fps. Representando graficamente para frequências menores o resultado pode ser visto em 3.5 , onde a inclinação das caudas para as diferentes frequências é muito próxima. A inclinação do ajuste para a cauda do histograma de 145 fps é $(-1.79 \pm 0.13)$.

As Figuras 3.4 e 3.5 são representações gráficas em log-log dos mesmos dados usados para o histograma da Figura 3.3a. Os dados desse gráfico foram feitos escolhendo uma janela de tamanho 0.01, de forma que os pontos fiquem igualmente espaçados entre si. 


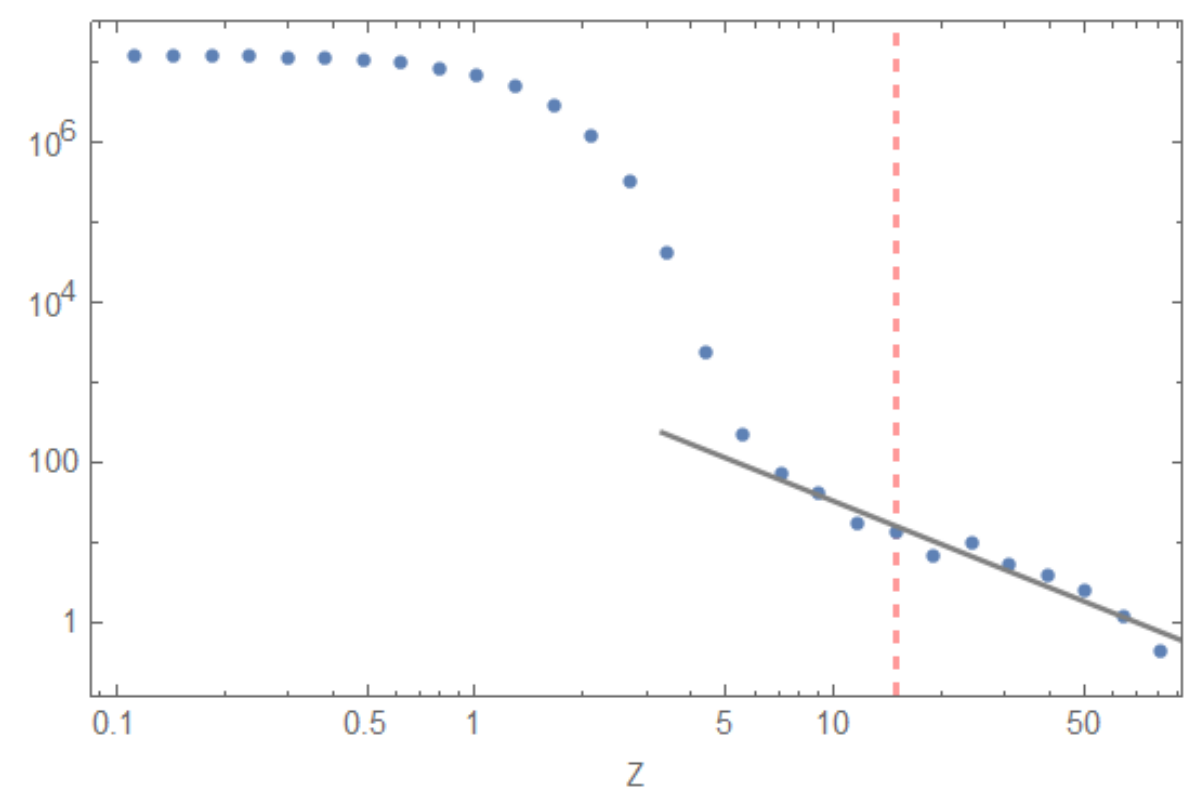

Figura 3.4: Ajuste com uma lei de potência para cauda do histograma de frequência 145 fps para o Grupo Experimental \#2. A lei de potência forma uma reta na representação log-log, e nesse caso os parâmetros da reta são $(7.61 \pm 0.44)-(1.79 \pm 0.13) x$. A linha espessa tracejada em vermelho é o limite dos dados experimentais anteriores.

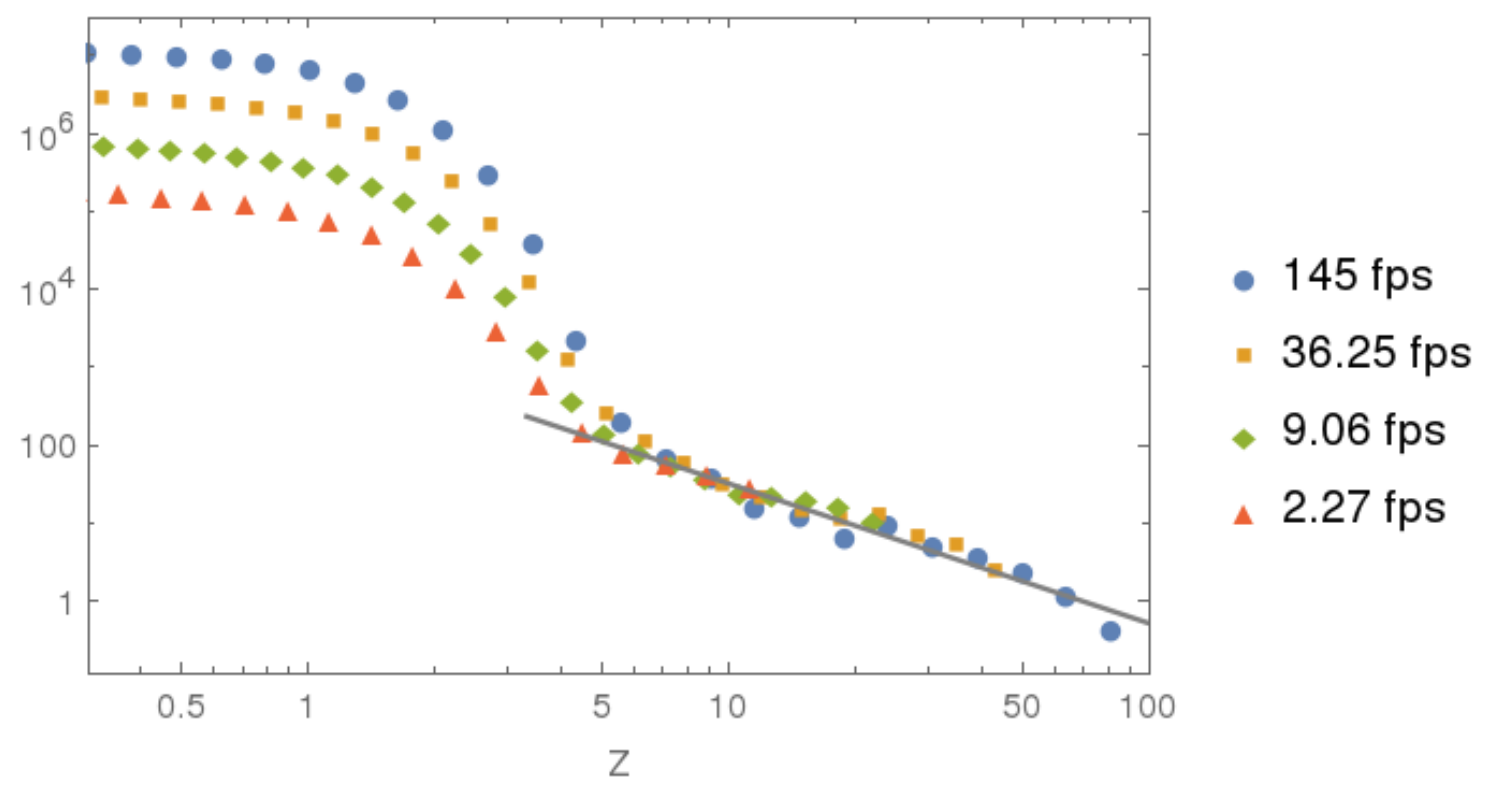

Figura 3.5: Histograma para diferentes frequências especificadas na legenda. A curva de 145 fps é a mesma de 3.4. e a curva contínua do ajuste também é a mesma.

\subsubsection{Relação cauda versus tempo}

Nota-se que nos histogramas da Figura 3.3 o valor dos $Z$ s diminui com a diminuição da frequência, sugerindo que possa haver correlação entre essas duas grandezas. Para estudar essa relação foram escolhidos os dados máximos dos $Z_{\mathrm{s}}$ nos histogramas do Grupo Experimental \#2 da seguinte forma: nos histogramas em que há alguns pontos nos extremos das caudas que estão muito distantes da cauda central, esses pontos são considerados outliers e 
portanto não considerados; tomando os outros pontos que ainda permanecem nos extremos, mas juntos do aglomerado central de pontos, foram escolhidos 10 pontos de cada lado do histograma e fez-ze a média desses valores absolutos. Esse valor é então definido como $\max (Z)$. Convertendo frequência para tempo, obtemos o resultado da Figura 3.6, que é um gráfico log-log dos dados. As retas tracejada e contínua na Figura 3.6 são respectivamente os ajustes para todos os pontos, e para todos os pontos excentuando-se o primeiro, pois este é o de maior desvio da curva ajustada. O ajuste feito foi por uma lei de potência a. $x^{b}$, por isso na Figura 3.6 as curvas aparecem como retas, e o parâmetro $b$ corresponde à inclinação da reta.

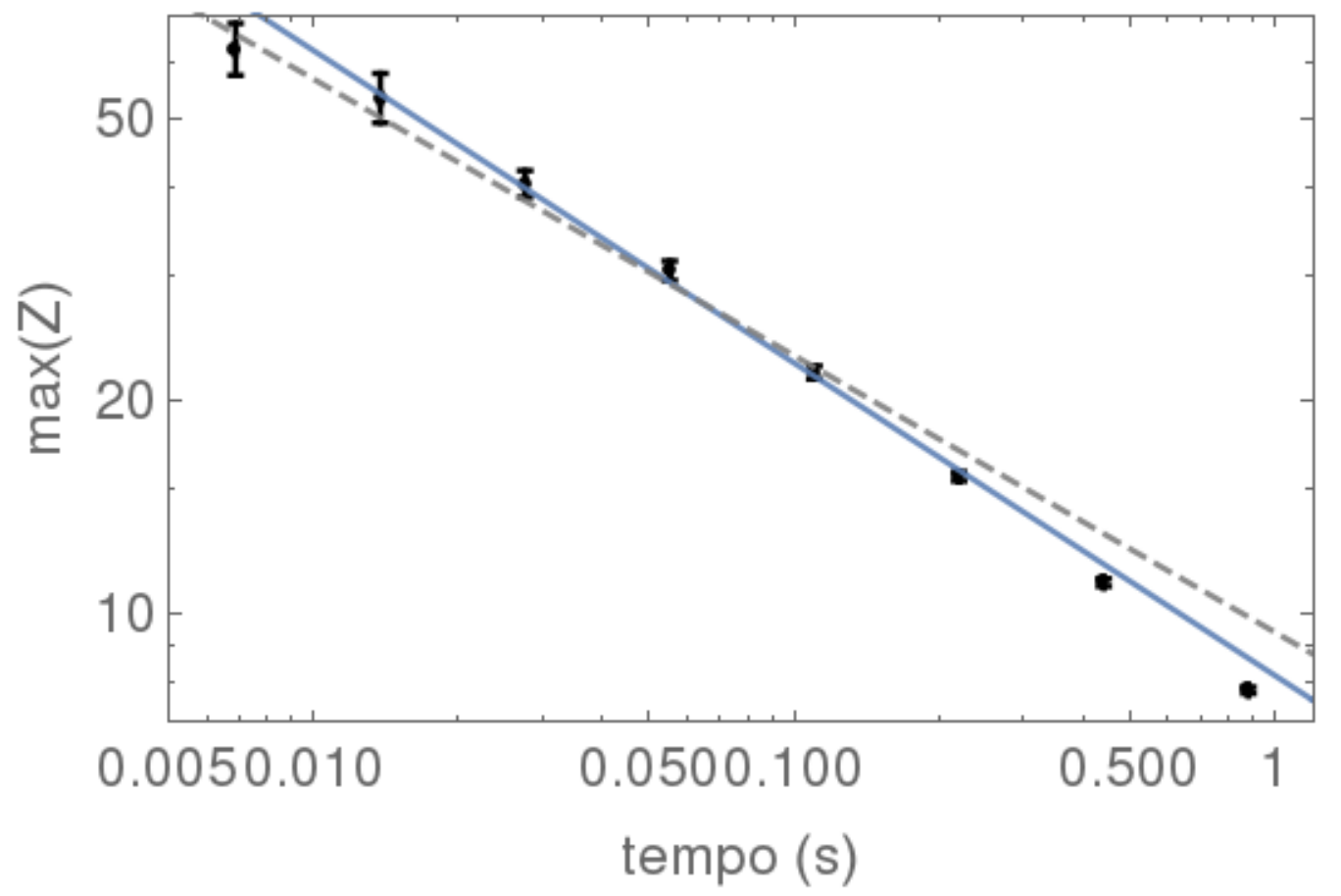

Figura 3.6: Gráfico da cauda máxima vs. tempo. Ajuste para as leis de potência, que na representação log-log ficam como retas: a) reta tracejada: $(-0.391 \pm 0.022) \mathrm{x}+(9.393 \pm 0.896)$, b) reta contínua: $(-0.441$ $\pm 0.011) \mathrm{x}+(8.160 \pm 0.323)$

Além dos experimentos feitos demonstrados na Tabela 3.1, fez-se mais um Grupo Experimental com frequência de aquisição igual a 200 fps, contendo 68 microesferas, porém contendo somente 4100 imagens. Este não foi considerado até agora pois contém metade do número de imagens trabalhadas anteriormente. Utilizamos os dados desse experimento para efetuar a mesma análise de cauda máxima vs. tempo a fim de comparar as inclinações das retas encontradas. O ajuste de $\max (Z)$ com o tempo (inverso da frequência) é feito a partir de uma lei de potência e é mostrado na Figura 3.7 .

As Figuras 3.6 3.7 mostram que as inclinações das caudas são diferentes, além disso o experimento da Figura 3.7 tem poucas microesferas, em comparação ao experimento da Figura 3.6. na Figura 3.7 o ajuste em lei de potência para os pontos produziu uma inclinação bem diferente que a da Figura 3.6, o que pode ser devido ao efeito da média. Fazendo a mesma análise para os experimentos da Tabela 3.1 nota-se uma variação grande nas inclinações das retas ajustadas, havendo variação grande nos pontos para as frequências mais baixas (tem- 


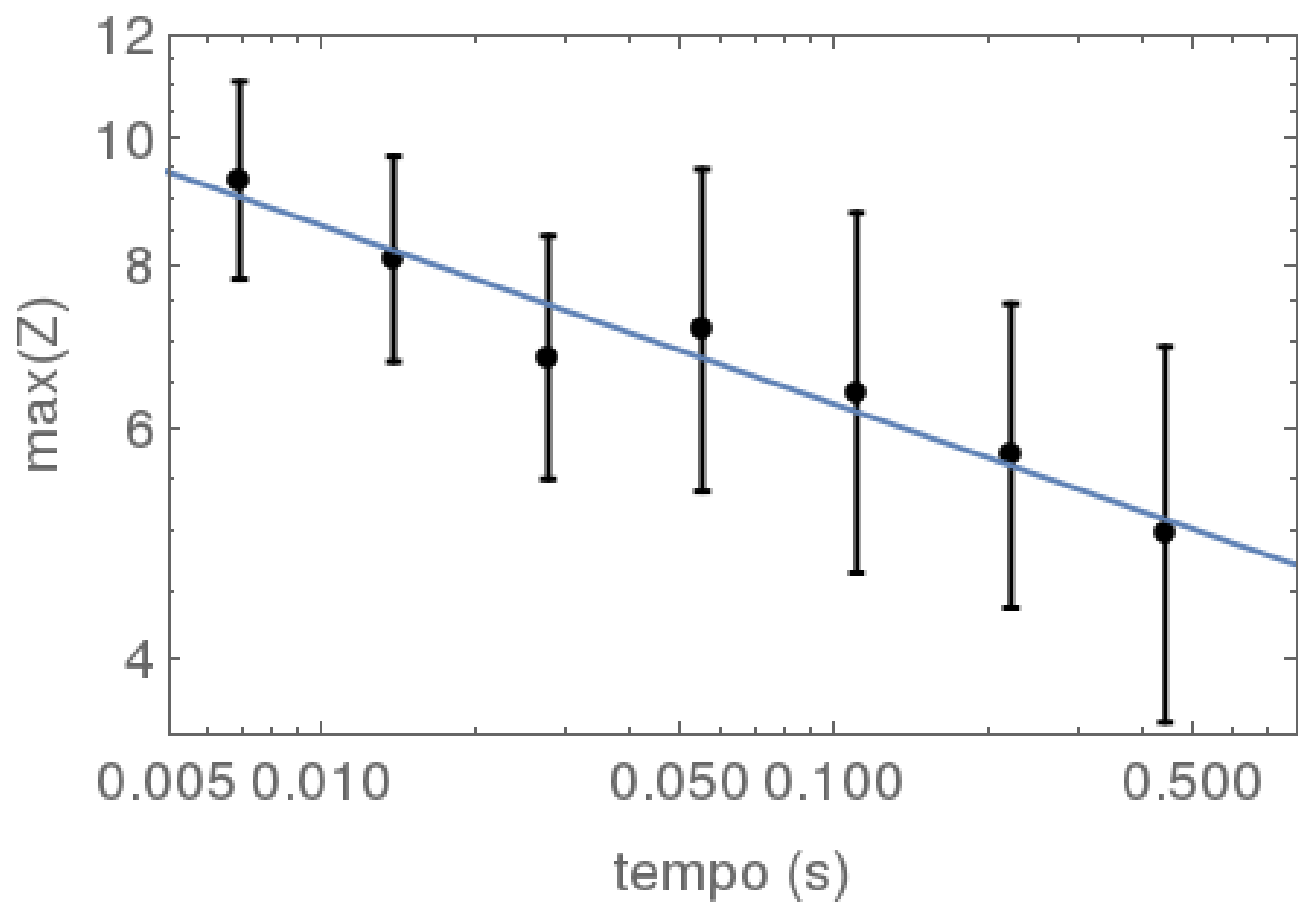

Figura 3.7: Gráfico da cauda máxima vs. tempo para o experimento de frequência máxima igual a 200 fps, contendo 68 microesferas e 4100 frames. Ajuste para lei de potência, que no gráfico $\log$-log fica uma reta: $(4.56 \pm 0.26)-(0.14 \pm 0.02) \mathrm{x}$.

pos mais altos), provavelmente por conta do número de pontos, pois nas frequências mais baixas o número de pontos considerados diminui consideravelmente, por exemplo, para a frequência 18 fps temos apenas $12.5 \%$ dos pontos originais).

É importante realçar que $Z$ é um número adimensional, pois é o deslocamento normalizado pelo desvio padrão. É possível fazer a mesma análise feita com os valores do deslocamento não absolutos (não normalizados). O resultado é mostrado na Figura 3.8. Dessa vez utilizou-se um método diferente: olhando para os últimos pontos dos histogramas de $Z$, foram escolhidos os 50 últimos pontos das duas extremidades e tomou-se os valores absolutos destes, então foi calculada a mediana desse conjunto. Agora, como o deslocamento não é normalizado, tem-se o valor da movimentação real na difusão anômala, que corresponde ao deslocamento da microesfera.

A figura mostra que para os primeiros valores de tempo o valor do deslocamento atinge um patamar, diminuindo consideravelmente no final da curva. A informação que obtemos desse gráfico é a de que estamos chegando na ordem de grandeza do tempo na qual os saltos anômalos acontecem, pois para um tempo menor (frequência maior), o valor do deslocamento não aumenta, sendo o deslocamento no salto anômalo da ordem de $1.59 \mu \mathrm{m}$ ocorrendo em um intervalo de tempo próximo de $0.01 \mathrm{~s}$. 


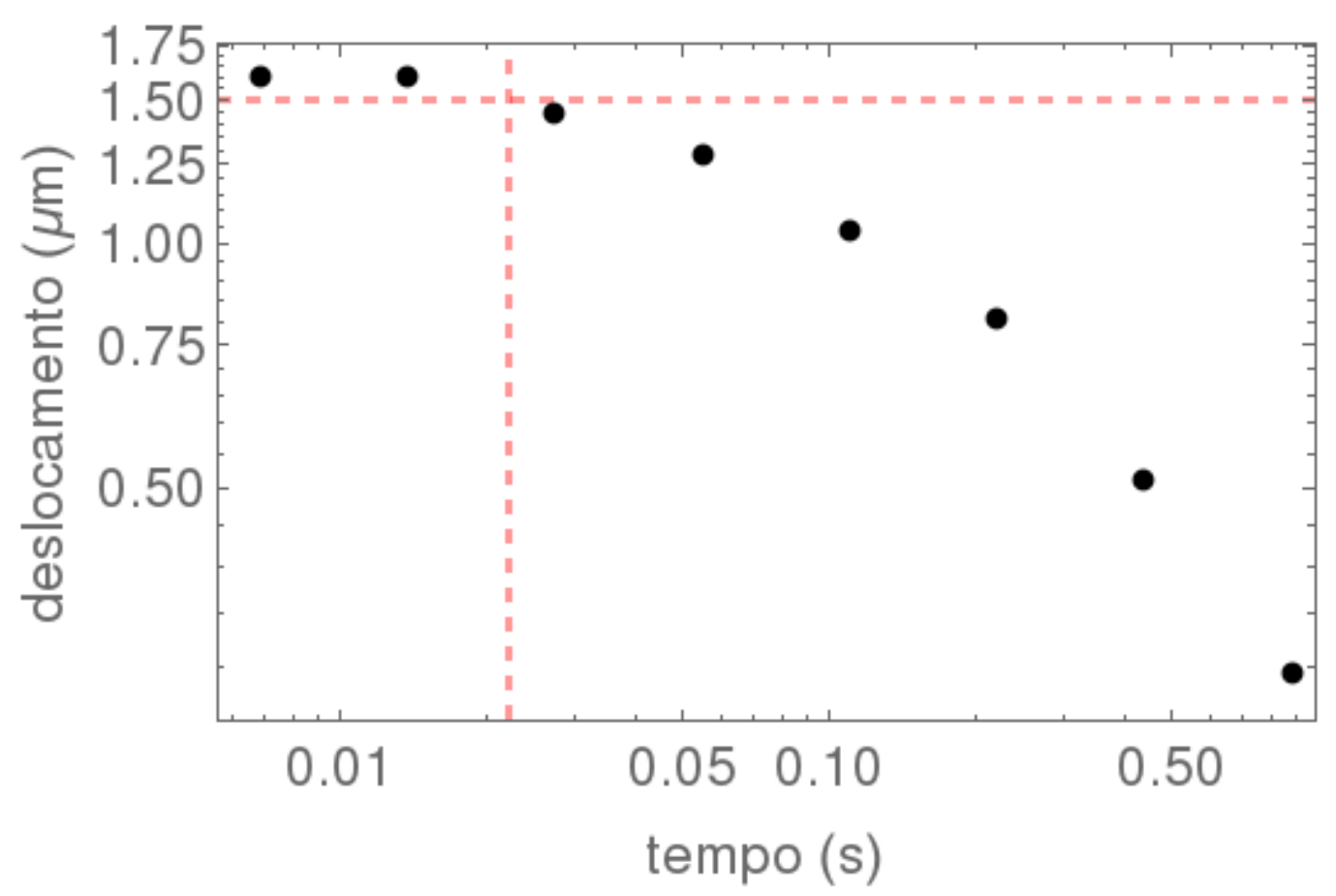

Figura 3.8: Deslocamento máximo na difusão anômala feito pelas microesferas em função do tempo (tomados como inverso da frequência de aquisição) para os dados do Grupo Experimental \#2. As linhas espessas tracejadas em vermelho indicam no quadrante superior esquerdo a região onde o valor do salto não aumenta com a diminuição do tempo.

\subsubsection{Correlação na movimentação das microesferas}

Como o aparato do experimento é muito sensível, pequenas interferências podem alterar as imagens que estão sendo adquiridas durante a tomada de dados. Com isso nos perguntamos, nos dados adquiridos há alguma mudança de posição abrupta que poderia representar um momento em que alguém se apoiou na mesa do microscópio, por exemplo? Se isso acontecer devemos observar uma mudança abrupta na posição da maioria dasnh microesferas persistindo durante um intervalo de tempo.

Para responder a essa pergunta foram feitos gráficos para o número de saltos simultâneos maiores que três em cada intervalo de tempo. Nos histogramas das figuras anteriores é possível observar que a curva experimental começa a descolar da gaussiana a partir de $\mid Z$ $1 \geq 3$, por isso o gráfico de contagens foi feito para as contagens maiores que 3 (Fig. 3.9). Os gráficos foram feitos considerando a magnitude dos saltos $Z \mathrm{x}$ e $Z \mathrm{y}$ para todas as aquisições de imagens a fim de validar os dados que tomamos.

Para cada frame foram contadas quantas esferas fizeram um salto $|Z|>3$; para uma contagem igual a 0 significa que naquele frame nenhuma esfera realizou um desses saltos anômalos. Para esse experimento em particular, ver Figura 3.9, foi encontrado que para o eixo y, no máximo 3 esferas deram saltos maior que 3 em 13 instantes de tempo. Caso esse fenômeno fosse um artefato experimental, esperaríamos um número bem maior de esferas tendo esses saltos.

Os gráficos da Figura 3.9 mostram o comportamento de apenas uma das séries de dados 


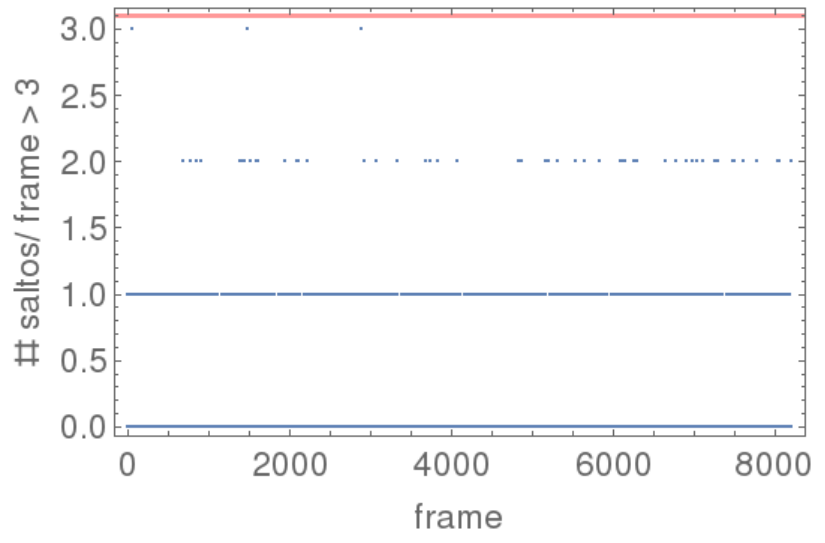

(a) eixo $\mathrm{x}$

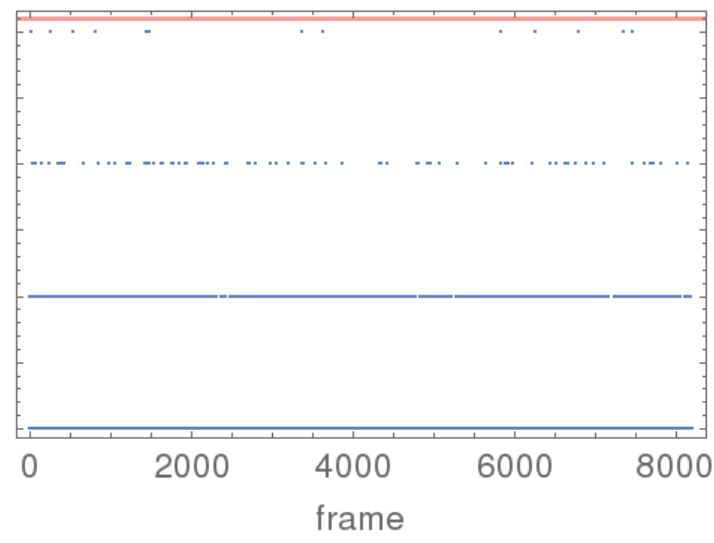

(b) eixo y

Figura 3.9: Gráfico do número de contagens maiores que 3 para cada frame, em um total de 8200 frames para uma série de dados tomada que contém 45 microesferas. A linha espessa em vermelho indica onde menos de $7 \%$ das esferas deram saltos $|Z|>3$ em cada frame.
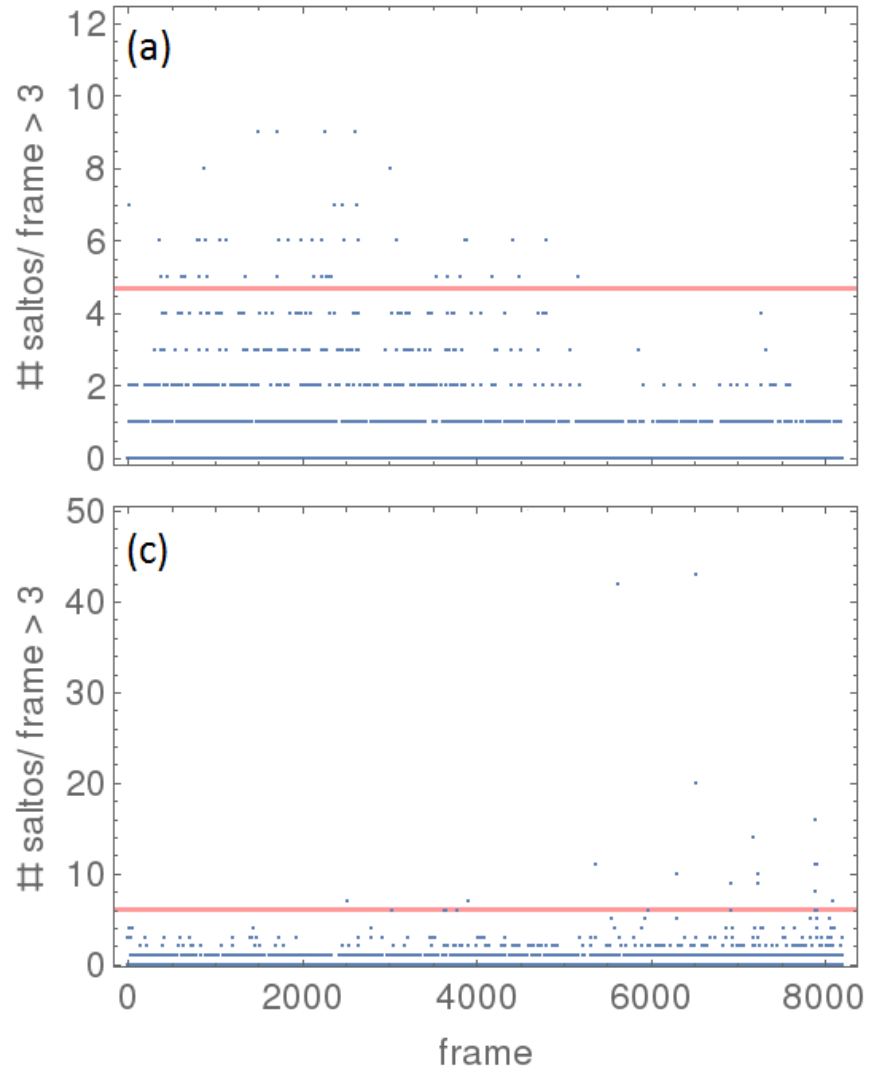

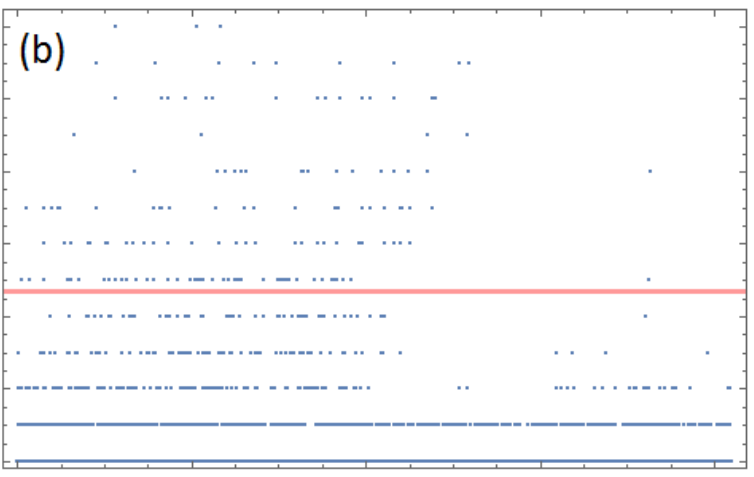

(d)

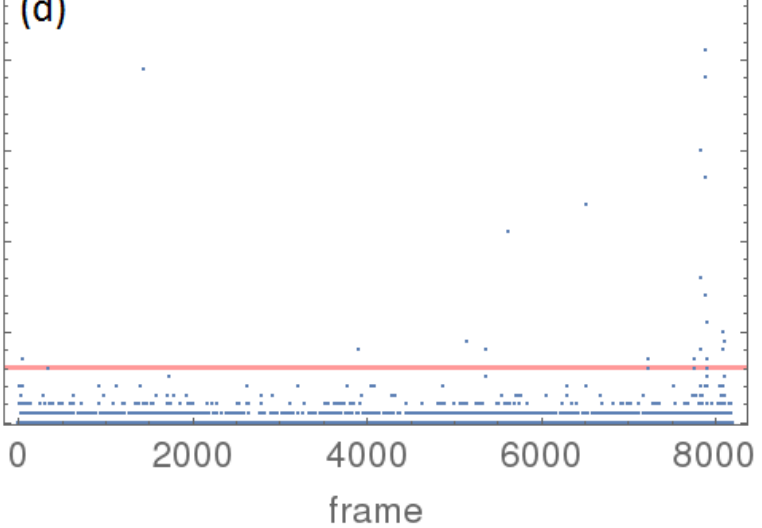

Figura 3.10: Gráficos das contagens para os casos 1) em que há maioria de movimentos ativos do citoplasma (figuras (a) - eixo x, e (b) eixo y), amostra com 47 microesferas e 2) em que há muitos saltos altos em um único instante como decorrência de um processo aleatório (figuras (c) eixo x, e (d) eixo y), amostra com 61 microesferas. Nas figuras a linha espessa em vermelho indica onde menos de $10 \%$ das esferas deram saltos $|Z|>3$.

tomadas, correspondente a 45 microesferas, e por ele é possível ver que não houve nenhum conjunto de contagens muito abruptas próximas temporalmente, o que valida os dados que obtivemos nesse conjunto. Poderíamos obter uma taxa alta de contagens em um caso em 
que estivéssemos observando uma região mais ativa do citoplasma celular, ou ainda um evento no qual a maioria das microesferas tiveram saltos $|Z|>3$. Neste último caso, que a princípio caracterizaria apenas um evento aleatório, observaríamos apenas um ponto isolado no histograma das contagens, como é possível ver na Figura 3.10, figuras (c) e (d) nos frames 5622 e 6526 tanto para o eixo x como para o eixo y, sendo essa série composta de 61 microesferas. Contudo, ainda existe uma chance alta de esse ser um artefato experimental, pois ao retirar-se o movimento de deriva (coletivo) da movimentação geral das esferas pode ocorrer de uma esfera com pouca movimentação ficar com um deslocamento maior que o original. No primeiro caso, referente à situação da Figuras 3.10, figuras (a) e (b), nessa série é possível ver que na primeira metade dos instantes de tempo ocorreram muitas contagens altas tanto no eixo x quanto y, o que mostra a movimentação mais ativa do citoplasma; nesse exemplo a série continha 47 microesferas. As Figuras em 3.10 mostram uma reta espessa em vermelho indicando a partir de qual contagem menos de $10 \%$ das microesferas tiveram saltos $|Z|>3$. Para todas as séries de dados foi feita essa análise da contagem dos eventos e os casos aqui relatados foram os comportamentos gerais observados.

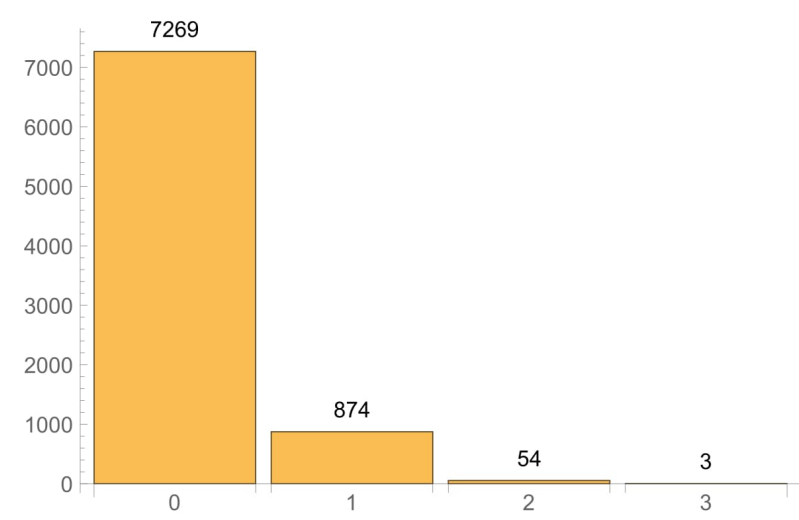

(a) eixo $\mathrm{x}$

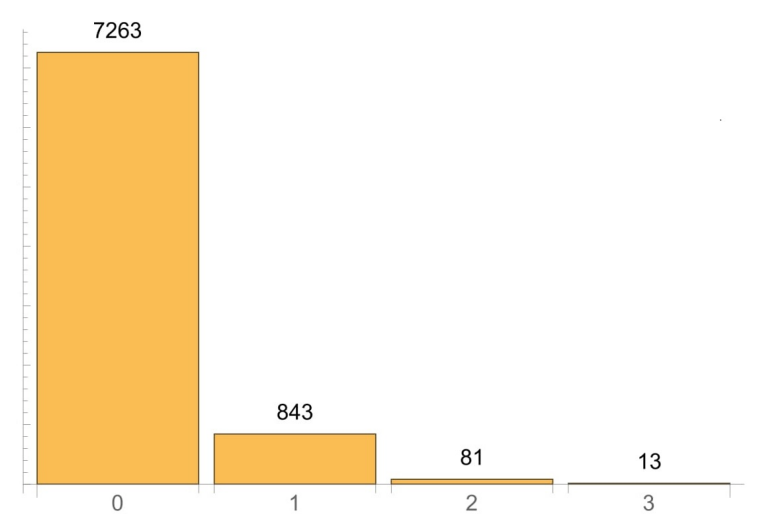

(b) eixo y

Figura 3.11: Histograma da contagem dos eventos (contagens maiores que três) referente à figura 3.9 .

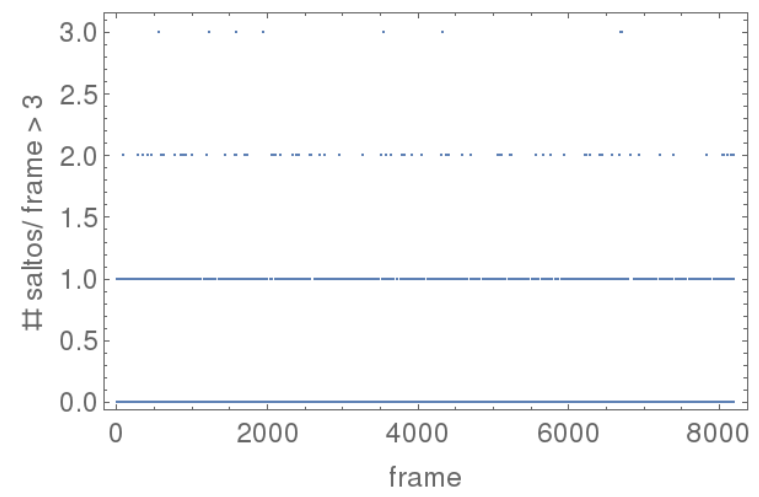

(a)

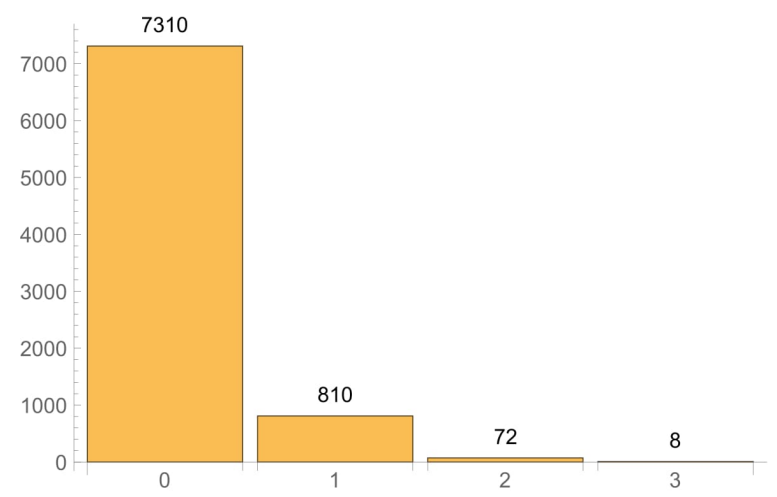

(b)

Figura 3.12: Simulações do gráfico de contagem para o eixo x (a) e histograma desse gráfico para as contagens (b). 
A fim de evidenciar o caráter aleatório desses dois comportamentos mostrados nas imagens da Figura 3.9, foram feitos dois histogramas respectivos a essas imagens (Fig. 3.11) e usando esses histogramas foram calculadas as probabilidades de uma dada microesfera dar um número de saltos $|Z|>3$ em um intervalo de tempo; ou seja, o objetivo é determinar em quantos frames ocorreu 1 evento com salto maior que 3, e calcular a probabilidade de haver 1 salto em 8200 frames, e assim por diante para 2 eventos, 3 eventos e maior que 3 eventos. Com essas probabilidades foi feita uma simulação, somente para o eixo x, visto que para o eixo y é similar, que deram como resultado as Figuras 3.12 , onde os resultados se assemelham muito às Figuras de 3.9 e 3.11.

A Figura 3.12a é o gráfico da simulação usando as probabilidades da Figura 3.11a, e a Figura $3.12 b$ é o histograma referente ao gráfico da simulação.

Os gráficos das contagens permitem avaliar correlações entre a movimentação das microesferas, e é possível afirmar que na maioria dos casos não existe correlação na movimentação destas. 


\section{canoun 4}

\section{Conclusões}

O objetivo deste trabalho foi estudar a movimentação de micropartículas em células RASM (rabbit aortic smooth muscle) que ficam aderidas ao citoesqueleto da célula. As células com as micropartículas são observadas através de um microscópio com uma câmera acoplada e ligados em um computador, onde as imagens obtidas são armazenadas. Um aspecto que surgiu nesse trabalho foi a necessidade de se quantificar o quanto se pode errar na medida da posição do centro de massa (CM) das microesferas detectadas, pois o programa que analisa a posição do CM pode errar no cálculo pois ele se baseia na intensidade dos pixels da imagem analisada, e experimentalmente as imagens contém um ruído que acrescenta uma distorção no cálculo.

A fim de verificar a influência dos parâmetros no erro da posição da microesfera, foi feita uma simulação para testar a influência de cada característica, como diâmetro da microesfera, tamanho da região de interesse, nível de ruído da imagem e limiar usado, no erro final na detecção da posição da microesfera. O programa que analisa a posição do CM das microesferas define uma janela em volta da microesfera detectada, que é a região de interesse, e para determinar o CM usa um limiar para retirar o fundo da imagem de forma que ele não interfira no cálculo do CM, pois ele é feito como uma média ponderada pela intensidade do pixel. As imagens obtidas são em tons de cinza, e na leitura da imagem o computador coloca o preto no 0 e 255 no branco, e nas simulações a relação foi invertida para que o nível de tons escuros tivessem intensidade maior.

Notou-se que usando maiores valores de limiares $(T h)$ o erro diminui, e para um $T h>35 \%$ de 255 o erro fica menor que 1 pixel, independente do diâmetro da microesfera. Para o diâmetro de 10 pixels o limiar bom de trabalho é acima de $35 \%$ de $T h$, pois o erro é mínimo. Também se notou que para níveis de ruído de fundo baixos o erro é menor, o que faz sentido pois como a intensidade do pixel é baixa, ela acrescenta pouco no cálculo do CM.

A análise da movimentação das microesferas anexadas ao CSK revelou a movimentação anômala que estas possuem. Os dados obtidos para os histogramas dos $Z$ s estão de acordo com o que se encontrou na literatura, e com os dados obtidos pela aluna Mariana S. A. 
Ferraz, no seu trabalho de doutorado, no qual também foi usado o mesmo tipo de célula, a célula RASM. Os dados começam a descolar da gaussiana para $|Z|>3$; a movimentação térmica difusiva pode ser explicada pela região central do histograma, que se ajusta bem com a gaussiana, e a cauda alongada é a parte da movimentação anômala. Além disso o MSD encontrado para as partículas de prova também é consistente com os dados da literatura, sendo que para tempos menores que 1 segundo o movimento é subdifusivo, e para tempos maiores que 1 segundo o movimento superdifusivo.

Com a câmera sendo capaz de chegar a altas frequências, foi possível observar os saltos anômalos dados pelas microesferas na escala de tempo em que eles ocorrem, tendo o salto tamanho máximo de $1.60 \mu \mathrm{m}$ ocorrendo em um intervalo da ordem de 0.01s. Um aspecto importante a ser considerado, é que os trabalhos na literatura não conseguem chegar na frequência que dá esse tempo de $0.01 \mathrm{~s}$, e com a câmera e a implementação do microcontrolador, foi possível atingir escalas menores de tempo que as usuais, contudo mais experimentos são necessários para refinamento dos dados.

Ademais, foi possível evidenciar a cauda dos histogramas da magnitude dos deslocamentos, onde conseguimos popular a curva na representação log-log desses histogramas, justamente por conta da alta frequência da câmera e da quantidade de dados coletados. Esse representa um resultado novo pois na cauda da gaussiana já documentada na literatura não era possível verificar que o comportamento é do tipo lei de potência. Na literatura os experimentos costumam ser feitos com 200 a 400 microesferas, e não se chega a uma frequência muito alta. Os resultados obtidos para a cauda dos histogramas corrobora com os resultados existentes sobre a invariância de escala, e também é consistente com o trabalho de doutorado da Mariana [40] e apresentada no artigo publicado por ela e pelo professor Adriano Alencar sobre cytoquake, de que o CSK das células vivas exibe abruptas reconfigurações locais e transmissão de movimentos detectáveis a longa distância, semelhante às observações de abalos sísmicos na crosta terrestre.

O trabalho teórico publicado por D. Stamenović [45] na revista Nature mostra através da Figura 3.2 que para tempos menores que 0.01 s a dinâmica dos eventos detectados ocorrem na rede de actina, e tem regime superdifusivo $(\beta>1)$. Nos dados encontrados neste trabalho conseguiu-se obter uma região ainda não explorada para intervalos temporais abaixo de 0.01s, onde foi verificado que este ponto segue a tendência dos seguintes, i.e., está dentro do ajuste esperado para o regime de 0.01 s e 10 s que é o subdifusivo $(\beta<1)$.

Ressalta-se que só foi utilizada um tipo de célula (RASM) que é uma célula de músculo, que possui alta atividade mecânica. Outros trabalhos usando células que possuem baixa atividade mecânica, como por exemplo células do epitélio, ou células que possuem mais alta atividade mecânica como cardiomiócitos, que são células pulsantes, podem apresentar resultados distintos pois suas funções específicas no organismo vivo são diferentes. 


\section{corates A}

\section{Atividades Acadêmicas}

- Cursadas as disciplinas: Mecânica Quântica I (2015), Preparação Pedagógica de Ensino (2015), Mecânica Estatística (2015), Abordagem Física no Estudo de Células Vivas (2015), Modelos em Biofísica (2016) e Tópicos Avançados em Tratamento Estatístico de Dados em Física (2016).

- Participação no II Workshop do Laboratório de Microrreologia $\left(\mathrm{LabM}^{2}\right)$ ocorrido nos dias 2 e 3 de julho de 2015 no IF-USP (http://portal .if .usp.br/imprensa/pt-br/ node/819).

- Participação no Encontro de Física 2016, organizado pela SBF em Natal (3 a 7 de setembro de 2016) e apresentação de pôster (http://www1.sbfisica.org.br/eventos/ enf /2016/programa/trabalhos . asp?sesId=124\&ar=1).

- Participação na escola de verão: VI Southern-Summer School on Mathematical Biology de 23 a 27 de janeiro de 2017 (http://www.ictp-saifr.org/?page_id=13370).

- Participação nas reuniões semanais do $\mathrm{LabM}^{2}$ e ajudou a organizar alguns seminários internos que foram feitos dentro do grupo (http://fig.if.usp.br/ labm2/). 


\section{Apêndice $\mathbf{D}$}

\section{Microesferas Ferrigmagnéticas}

Foram compradas em Harvard School of Public Health, e suas características estão descritas na Tabela B.1.

Tabela B.1: Características das microesferas utilizadas.

\begin{tabular}{lc}
\hline Batch & B29 \\
\hline Data & 17 -Oct-13 \\
Constante $(\mathrm{Pa} /$ Gauss $)$ & 2.001 \\
Diâmetro $(\mu \mathrm{m})$ & 3.58071 \\
Desvio padrão $(\mu \mathrm{m})$ & 0.178141 \\
$\%$ & 0.04975 \\
beads $/ \mathrm{ml}$ & $2.62 \mathrm{E}+07$ \\
unitbeadvolume $\left(\mu \mathrm{m}^{3}\right)$ & 24.03772 \\
unitbeadsmass $(\mathrm{mg})$ & $1.2018856 \mathrm{E}-7$ \\
$\mathrm{mg} / \mathrm{ml}$ & 3.14894 \\
Área $\left(\mu \mathrm{m}^{2} / \mathrm{ml}\right)$ & 1055332863.06244 \\
$\mathrm{ml}$ & 3.5 \\
$\mathrm{mg}$ & 11.02129434 \\
$\mu \mathrm{l} / \mathrm{mg}$ & 317.567056 \\
\hline
\end{tabular}




\section{Apêndice}

\section{Calibração das Câmeras}

As câmeras estão calibradas na relação $\mu \mathrm{m} /$ pixel. A calibração da câmera Andor Neo sCMOS é mostrada na tabela C.1.

Tabela C.1: Calibração da câmera Andor neo sCMOS.

\begin{tabular}{ll}
\hline Objetiva & $\mu \mathrm{m} /$ pixel \\
\hline $10 \mathrm{x}$ & $0.648 \pm 0.324$ \\
$20 \mathrm{x}$ & $0.324 \pm 0.162$ \\
$40 \mathrm{x}$ & $0.162 \pm 0.081$ \\
$63 \mathrm{x}$ & $0.103 \pm 0.052$ \\
\hline
\end{tabular}


Apêndice

\section{Caracterização de CCDs}

A câmera utilizada no laboratório LabM² é Andor neo sCMOS, tipicamente uma câmera usada na astronomia, e como nesta área é necessário um tratamento de imagens mais acurado, nesta seção queremos entender os fatores que causam erro nas imagens obtidas, por isso os conceitos discutidos adiante estão baseados na referência [21]. Esta referência trata dos fatores que causam erros em em câmeras CCD, porém como os dispositivos CCD e CMOS são similares, as fontes que causam os erros permanecem os mesmos.

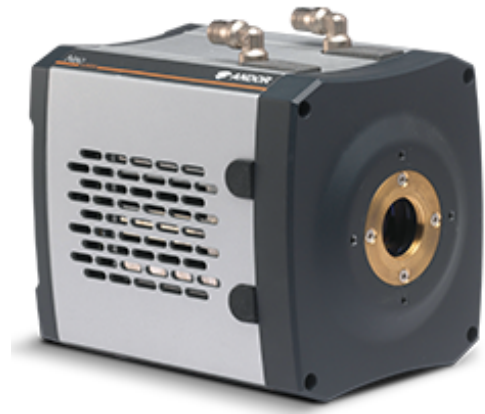

(a)

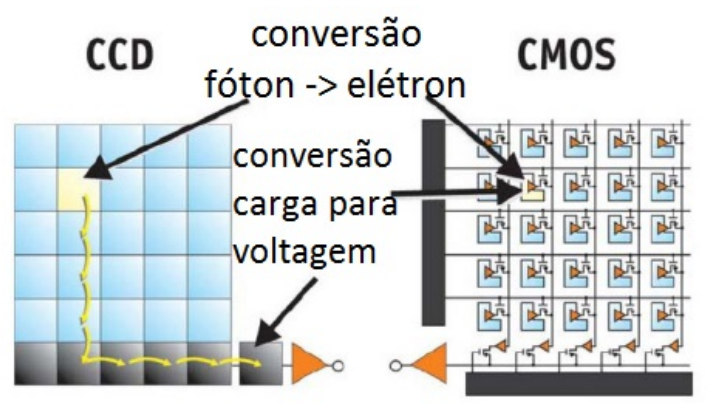

(b)

Figura D.1: (a) Imagem da câmera Andor neo sCMOS usada no LabM². (b) Esquema da diferença entre detectores CCD e CMOS. Imagens retiradas da internet.

Detectores CCD são dispositivos cujo princípio de funcionamento é o efeito fotoelétrico; os fotoelétrons produzidos são armazenados na região de depleção de um capacitor constituído de 3 camadas (MIS): metal, isolante, semicondutor, e as fileiras e colunas, contém vários desses capacitores colocados de forma a ficarem muito próximos. Quando uma quantidade específica de carga é coletada dentro do pixel durante uma integração, não é possível saber qual foi a fonte que gerou o elétron, isso porque ele tanto pode ser um fotoelétron ou um elétron gerado por movimento térmico no CCD. Na prática não existem CCDs uniformes, e para entender o sinal captado, é preciso entender o ruído que também é gerado. Vamos discutir brevemente algumas das fontes que podem introduzir erros nos CCDs. 
Ruído de leitura (read noise): é o número de elétrons introduzidos por pixel no sinal final após a leitura do dispositivo. Este ruído pode ter duas fontes diferentes: 1) a conversão de um sinal analógico para digital não se repete identicamente todas as vezes; cada amplificador on-chip e circuito A/D produzem uma distribuição estatística de possíveis respostas centradas em um valor médio; 2) a própria eletrônica introduz elétrons espúrios no processo, produzindo flutuações aleatórias não desejadas na saída. Estes dois efeitos combinados produzem uma incerteza no valor final de cada pixel. O nível médio (1 sigma) de incerteza é o ruído de leitura e é limitado pelas propriedades eletrônicas do amplificador de saída on-chip e a eletrônica de saída. O tamanho físico do amplificador on-chip, a construção do circuito integrado, a temperatura do amplificador, e a sensitividade (geralmente perto de 1-4 $\mu \mathrm{V}$ por fóton detectado $=$ fotoelétron), todos esses fatores contribuem para o ruído de leitura. Neste micro mundo, os valores para o ruído eletrônico são altamente relacionados às propriedades térmicas do amplificador, que por sua vez determinam a sensitividade para cada pequena voltagem de saída. A velocidade de leitura, e deste modo a taxa com a qual a corrente flui através do amplificador on-chip, podem causar oscilações térmicas na temperatura do amplificador, as quais podem afetar o nível de ruído de leitura resultante. Técnicas de produção de circuitos integrados como o design do amplificador, métodos de marcagem de pixels, e esquemas de dopagem dos semicondutores podem ser usados para melhorar o desempenho da eletrônica de saída.

Corrente negra (dark current): todo material muito acima do zero absoluto está sujeito a um ruído térmico. Quando a agitação térmica é alta o suficiente os elétrons são liberados da camada de valência e são coletados dentro do poço de potencial do pixel, de forma que no momento em que ocorre a leitura, esses elétrons são interpretados como parte do sinal. Como a presença desses elétrons dependem da temperatura de operação do CCD, em geral as câmeras possuem algum tipo de sistema de resfriamento. O nome dark current deriva do fato de a interferência estar presente mesmo quando o sensor é ligado no escuro. A corrente negra para um CCD é geralmente especificada como o número de elétrons gerados por segundo por pixel, ou a corrente real gerada por unidade de área do dispositivo (dado em $\left.\mathrm{pA} / \mathrm{cm}^{2}\right)$. À temperatura ambiente, a corrente negra de um CCD típico é próxima de 2.5.10 ${ }^{4}$ elétrons/pixel/segundo; para dispositivos refrigerados essa corrente pode chegar de 2 a 0.04 elétrons/pixel/segundo, que embora seja um valor baixo, para uma exposição de 15 minutos, seria suficiente para acrescentar 1800 elétrons adicionais dentro do pixel do CCD após a leitura. Como a corrente negra segue uma distribuição de Poisson, o ruído real introduzido no sinal por esses elétrons térmicos é proporcional à raiz quadrada do valor dela.

Tendência (bias): é o ruído de nível nulo dentro do CCD, isto é, o valor produzido por um pixel não exposto. Para um pixel não exposto, o valor para zero fotelétrons coletados se traduzirá, após leitura e conversão A/D, em um valor médio com uma pequena distribuição 
em torno de zero. Para avaliar o ruído de nível nulo e sua incerteza associada utilizamse processos de calibração, sendo dois mais comuns: 1) determinar as regiões de overscan, isto é as regiões da borda que são perdidas quando a tela ajusta o tamanho da imagem para conseguir reproduzi-la, produzidas com todos os quadros de cada objeto: consiste basicamente de eliminar as bordas das imagens, 2) o uso de imagens da tendência suficiente para fazer observações sem exposição a luz (usando o obturador fechado), para um tempo de integração total de 0 segundos,isto é, tempo de abertura do obturador igual a 0 segundos, ou o mais baixo possível. Quando se utiliza as imagens de tendência para calibração, o melhor é tomar a média ou mediana da composição de 10 ou mais quadros (imagens) de tendência individuais. O processo de tirar a média elimina os raios cósmicos, que podem ser causados por materiais fracamente radioativos na construção do CCD, variações no ruído de leitura e flutuações aleatórias, que serão parte da imagem de tendência. 


\section{Apêndice}

\section{Protocolos de cultivo de células e de}

procedimentos para preparo experimental

Os procedimentos abaixo descrevem o cultivo para células RASM e fibroblastos de coração de rato WT (wild type) neonato e experimento de difusão anômala. Para outros experimentos ou células os procedimentos, a príncipio, podem mudar.

O meio para cultura de células pode variar para cada tipo de célula. Geralmente este é complementado com $10 \%$ de soro fetal bovino e 1\% de antibiótico. No caso da RASM foi utilizado meio de cultura DMEM high glucose (Gibco).

\section{E.1 Descongelamento de células}

Procedimento (supondo uma garrafa de cultivo de $25 \mathrm{~cm}^{2}$ ):

1. Retirar os tubos eppendorf necessários do botijão de nitrogênio líquido e levar para o fluxo laminar, juntamente com o restante do material a ser utilizado. Aquecer os eppendorfs contendo as células nas mãos movimentando-as até que todo conteúdo esteja descongelado;

2. Acrescentar $5 \mathrm{ml}$ de meio de cultura com $10 \%$ de soro fetal bovino e antibiótico em uma garrafa de $25 \mathrm{~cm}^{2}$;

3. Despejar o conteúdo do eppendorf nessa garrafa;

4. Colocar o material na incubadora de células para o crescimento e formação do tapete celular;

5. Anotar no livro de registro/planilha online as ampolas ou tubos retirados para o 
descongelamento.

\section{E.2 Cultivo de células}

Todo o procedimento de cultivo deve ser efetuado dentro do fluxo laminar. Para evitar contaminação utiliza-se pipetador automático.

Cuidados: Para cada pipetagem usar nova pipeta. Nunca retornar uma pipeta usada para o frasco de meio de cultura ou PBS.

Materiais Estereis:

- meio de cultura

- pipetas de $5 \mathrm{ml}$

- frascos de cultura

- tubo Eppendorf de $1 \mathrm{ml}$

- tubo Falcon de $50 \mathrm{ml}$

Materiais não Estereis:

- pipetador automático

- luvas

- avental

- gazes

- recipientes de descarte do meio e de pipetas

- caneta pemanente

- cadernos e protocolos

\section{E.2.1 Protocolo prévio}

1. Limpar o interior do fluxo laminar com gaze embebida em álcool $70 \%$ e toda a superfície de trabalho, e ferramentas a serem utilizadas (ex.: pipetadores);

2. Aquecer o banho Maria a $37^{\circ} \mathrm{C}$; 
3. Retirar o meio de cultura da geladeira e PBS e aquecê-los no banho Maria a $37^{\circ} \mathrm{C}$;

4. Colocar uma ponteira de vidro no aspirador de material biológico, tomando cuidado para que a mesma não encoste em nada pois ela entrará diretamente em contato com material celular;

5. Abrir a válvula de aspiração da capela;

6. Separar todo o material de trabalho que será utilizado limpando-os com álcool $70 \%$ e colocá-los dentro do fluxo, deixando o material em posição acessível.

\section{E.2.2 Manutenção de células em cultura permanente}

Materiais (assumindo frasco de cultura de $25 \mathrm{~cm}^{2}$ ):

- $50 \mathrm{ml}$ de meio de cultura e $10 \mathrm{ml}$ de PBS em temperatura ambiente;

- $1 \mathrm{ml}$ de Tripsina a $37^{\circ} \mathrm{C}$;

- 3 pipetas descartáveis de $5 \mathrm{ml}$;

- 1 tubo Falcon de 10 ml;

- 2 garrafas de cultura de $25 \mathrm{~cm}^{2}$.

- 1 ponteira de vidro

Procedimento:

1. Seguir protocolo prévio de limpeza;

2. Abrir a garrafa contendo as células e aspirar meio de cultura;

3. Lavar a camada celular com $5 \mathrm{ml}$ de PBS: pipetar o PBS, fechar a garrafa e balançá-la na horizontal levemente; abrir a garrafa e aspirar o PBS. Repetir esse processo por mais uma vez (totalizando duas vezes);

Cuidar para pipetar o PBS sempre do lado contrário ao tapete celular.

4. Adicionar $1 \mathrm{ml}$ de tripsina a $37^{\circ} \mathrm{C}$ e balançar a garrafa levemente para que ela cubra todo o tapete celular. Incubar o frasco por 2 a 5 min;

O tempo de incubação depende do tipo celular. A quantidade de tripsina depende do 
tamanho da garrafa usada.

5. Retirar a garrafa da incubadora e olhar no microscópio se as células ainda estão aderidas ao frasco. Caso elas ainda estejam grudadas no fundo da garrafa, é possível dar pequenas batidas na lateral da garrafa para as células soltarem da superfície;

6. Levar a garrafa ao fluxo de ar e adicionar $4 \mathrm{ml}$ de meio de cultura. Homogeneizar bem com a pipeta;

7. Coletar todo o inóculo e passar para um tubo Falcon de $10 \mathrm{ml}$;

8. Colocar o tubo Falcon na centrífuga em um ciclo de $1200 \mathrm{rpm}$ por $3 \mathrm{~min}$;

9. Levar o Falcon para o fluxo e sugar o sobrenadante;

10. Ressuspender as células com $2 \mathrm{ml}$ de meio de cultura;

11. Colocar $4 \mathrm{ml}$ em cada garrafa de cultura e acrescentar $1 \mathrm{ml}$ do inóculo do Falcon (teremos 2 frascos);

12. Identificar a garrafa com a linhagem, o número da passagem e data;

13. Colocar as garrafas na incubadora;

14. Repetir este procedimento quando as células se encontrarem com $90 \%$ de confluência.

\section{E.2.3 Troca de meio de cultura}

Materiais Estereis:

- $10 \mathrm{ml}$ de meio de cultura

- 1 pipeta de $5 \mathrm{ml}$

- 1 ponteira de vidro

Materiais não Estereis:

- Pipetadores

- Luva e jaleco 
- Gaze para limpeza

- Caderno/ protocolos, caneta

- Recipientes de descarte

Procedimento:

1. Retirar a garrafa da incubadora e examinar a cultura cuidadosamente no microscópio, observando sinais de contaminação e deterioração;

2. Levar a garrafa ao fluxo e aspirar o meio das células;

3. Lavar a garrafa com $5 \mathrm{ml}$ de meio de cultura;

4. Com uma nova pipeta acrescentar $5 \mathrm{ml}$ de meio de cultura a $37^{\circ} \mathrm{C}$;

5. Incubar a cultura.

\section{E.2.4 Concentração e contagem de células}

Materiais não Estereis:

- Câmera de Neubauer

- Azul de trypan

- Ponteiras

Procedimento:

1. Molhar as laterais da lâminula e colocar sobre a área marcada na câmara. Usar lamínulas especiais que fornecem a profundidade correta da câmara de contagem. Não usar lamínulas comuns;

2. Homogeneizar a suspensão celular e transferir com esterilidade $0.1 \mathrm{ml}(=100 \mu \mathrm{l})$ para um tubo eppendorf;

3. Acrescentar $100 \mu \mathrm{l}$ de azul de tripan no tubo eppendorf contendo as células e homogeneizar bem;

Fator de diluição: 2. As células estavam diluídas em $0.1 \mathrm{ml}$; nesta etapa estarão diluídas agora em $0.2 \mathrm{ml}$. 
4. Retirar uma alíquota de $0.1 \mathrm{ml}$ dessa diluição com uma pipeta e, encostando a ponta da pipeta na borda da lamínula, preencher cuidadosamente a câmara de contagem. Pode-se apenas enconstar a ponta da pipeta na câmara e esperar que ela se preencha por capiladridade. O líquido deve preencher apenas um lado da câmara e não deve chegar aos canais de cada lado da área de contagem. Depois pode-se virar a câmara e preencher do outro lado;

5. Deixar as células sedimentarem por 2 min;

6. Colocar a câmara no microscópio e focalizar nos quadrantes com a objetiva de menor aumento;

7. Contar as células nos 8 quadrantes e utilizar a equação:

$\frac{\text { número de células (8 quadrantes) x fator de diluição x 104 }}{8}=\frac{\text { número de células }}{m l}$

Essa equação fornece a concentração de células do inóculo.

Critérios para Contagem:

- Enumerar as células com núcleo bem visível

- Contar células isoladas como uma única célula

- Contar grumos constituídos por células facilmente distinguíveis por seus núcleos e citoplasmas como grupos de células isoladas e contar cada célula

- Grumos cujas células são difíceis de serem distinguidas umas das outras devem ser contados como um único grupo

\section{E.2.5 Câmara de Neubauer}

A câmera de Neubauer é composta por duas áreas espelhadas onde ficam os quadrantes de contagem E.1. Para fazer a contagem de células utilizam-se os quadrados das quatro esquinas (os quadrados que tem $1.00 \mathrm{~mm}$ de lado) e conta-se o número total de células visualizadas seguindo os critérios acima. A câmara tem profundidade de $0.1 \mathrm{~mm}$, por isso o volume total de cada quadrante de cada esquina é de $0.1 \mathrm{~mm}^{3}$. Fazendo a conversão de $\mathrm{mm}^{3}$ para $\mathrm{ml}$ é possível chegar na equação E.1. 


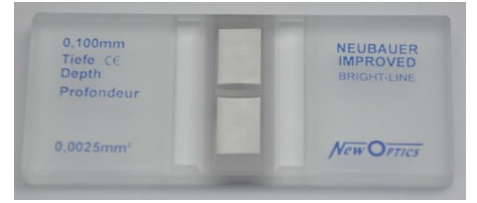

(a) câmara de Neubauer; a parte espelhada é onde ficam os quadrantes de contagem

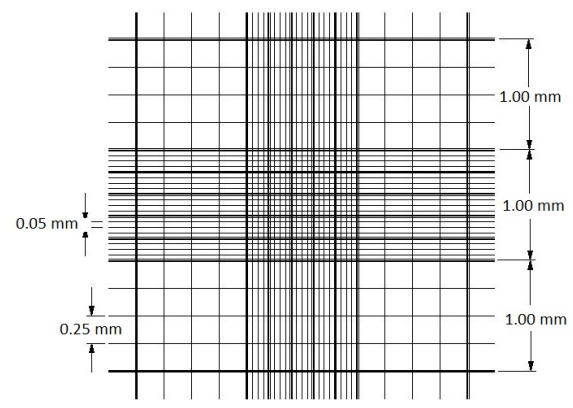

(b) esquema do quadrante de contagem; cada parte espelhada tem um quadrante desses.

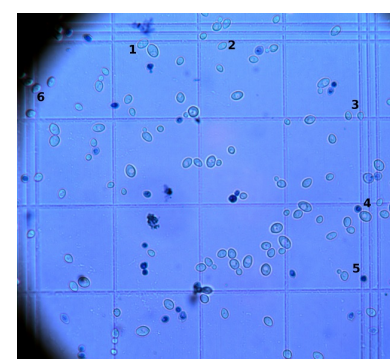

(c) exemplo de como enxergamos as células na região de contagem.

Figura E.1: Exemplo da câmera de Neubauer usada para contagem de células. Imagens retiradas da internet.

\section{E.3 Preparo de experimentos}

\section{E.3.1 Preparo da solução de esferas cobertas com RGD a uma concentração de $2 \mathrm{mg} / \mathrm{ml}$}

Material:

- Solução tampão (buffer) carbonato com pH = 9.4: revestimento das esferas para negativar a superfície destas e fazer com que o RGD, que tem carga positiva, fique aderido às esferas.

- PBS (phosphate-buffered saline): solução tampão para lavagem das esferas.

- $50 \mu \mathrm{g}$ ou $10 \mu \mathrm{l}$ de RGD que contém o peptídeo RGD para cada ml de esferas ferrimagnéticas (concentração: $5 \mathrm{mg} / \mathrm{ml}$ ).

- Solução estoque de esferas ferrimagnéticas (a esferas vem em solução de etanol).

Procedimento de preparo de $2 \mathrm{mg}$ de esferas ferrimagnéticas:

1. Vortexar a solução estoque de esferas em etanol para dispersar e separar as esferas que estão em agregados. O tempo para vortexagem pode variar, recomenda-se também sonicar a solução estoque utilizando ciclo padrão ( 5 ciclos de $30 \mathrm{~s}$ cada) pois o vórtex pode não ser suficiente para quebrar todos os agregados. Quando a solução está bem dispersa ela fica com cor mais acinzentada e homogênea.

2. Extrair imediatamente o volume necessário da solução estoque que contenha os $2 \mathrm{mg}$ de beads utilizando uma pipeta e colocar em um eppendorf; 
3. Agregar PBS ao eppendorf até obter um volume final de $1 \mathrm{ml}$;

4. Passar o eppendorf no vortex por aproximadamente $2 \mathrm{~min}$;

5. Colocar o eppendorf na centrífuga por 2 min a $14000 \mathrm{rpm}$;

Após a centrifugação as esferas ficarão todas concentradas no fundo do eppendorf, e o sobrenadante (PBS) em volta.

6. Despejar o conteúdo do eppendorf de uma vez para que as esferas não caiam junto, em um béquer ou em outro eppendorf de descarte;

Repetir as etapas 3, 4, 5 e 6 mais duas vezes (total de 3 vezes). Esse processo lava o bead tirando qualquer resquício de etanol para prepará-lo para revestimento com RGD.

7. Acrescentar $1 \mathrm{ml}$ da solução tampão carbonato no eppendorf;

8. Sonicar o conteúdo do eppendorf: 5 ciclos de $30 \mathrm{~s}$ cada, começando na potência mais baixa e aumentar até onde a solução não seja derramada para fora do tubo, tomando cuidado para o tubo não esquentar demais;

9. Adicionar $50 \mu \mathrm{g}$ (ou $10 \mu \mathrm{l}$ ) do eppendorf contendo RGD na solução de esferas;

10. Anotar no tubo eppendorf data de preparo da solução e concentração, e colocá-lo na roda giratória dentro da geladeira.

\section{E.3.2 Preparo de poços ou placas de Petri para adesão das esferas nas células}

1. Aquecer meio de cultura;

2. Vortexar a solução estoque de beads (ou sonicar se necessário) e separar uma quantidade dessa solução suficiente para a quantidade de poços ou placas de Petri que serão utilizadas. Essa estapa não precisa ser feita de forma esteril;

Retirar placas de Petri/poços da incubadora e levar para o fluxo laminar, juntamente com os materiais a serem usados e proceder protocolo de limpeza prévio e. A seguir:

3. Sugar meio dos poços ou placa de Petri; 
4. Lavar os 96 poços com $100 \mu \mathrm{l}$ de meio sem soro fetal ou PBS e acrescentar $100 \mu \mathrm{l}$ de meio sem soro em cada poço. Na placa de Petri, lavar com $1000 \mu$ l de meio sem soro ou PBS e acrescentar $1000 \mu \mathrm{l}$ de meio sem soro;

5. Pipetar $20 \mu \mathrm{l}$ (ajustar para fazer a deposição ideal) da solução de esferas em cada poço e incubar por 15 a 20 minutos. Para placa pode-se usar $40 \mu \mathrm{l}$;

6. Levar os poços (placa) para o fluxo e aspirar a solução destes;

7. Colocar $100 \mu \mathrm{l}$ de meio sem soro fetal aquecido;

8. Incubar os poços por 10 minutos;

9. Proceder o experimento com as células. 
APÊNDICE E. PROTOCOLOS DE CULTIVO DE CÉLULAS E DE 


\section{Referências Bibliográficas}

[1] http://fig.if.usp.br/ labm2/, June 2017.

[2] http://gibbs.engr.ccny.cuny.edu/technical/tracking/, June 2017.

[3] https://en.wikipedia.org/wiki/rheology, September 2017.

[4] https://micro-manager.org, June 2017.

[5] https://pt.wikipedia.org/wiki/trifosfato_de_adenosina, August 2017.

[6] Adriano Mesquita Alencar, Mariana Sacrini Ayres Ferraz, Chan Young Park, Emil Millet, Xavier Trepat, Jeffrey J. Fredberg, and James P. Butler. Non-equilibrium cytoquake dynamics in cytoskeletal remodeling and stabilization. Soft Matter, 12:8506-8511, 2016.

[7] Andreas R Bausch, Winfried Möller, and Erich Sackmann. Measurement of local viscoelasticity and forces in living cells by magnetic tweezers. Biophysical journal, $76(1): 573-579,1999$.

[8] David Boal and David H Boal. Mechanics of the Cell. Cambridge University Press, 2012.

[9] Predrag Bursac, Ben Fabry, Xavier Trepat, Guillaume Lenormand, James P Butler, Ning Wang, Jeffrey J Fredberg, and Steven S An. Cytoskeleton dynamics: fluctuations within the network. Biochemical and biophysical research communications, 355(2):324$330,2007$.

[10] Predrag Bursac, Guillaume Lenormand, Ben Fabry, Madavi Oliver, David A Weitz, Virgile Viasnoff, James P Butler, and Jeffrey J Fredberg. Cytoskeletal remodelling and slow dynamics in the living cell. Nature materials, 4(7):557-561, 2005.

[11] Linhong Deng, Xavier Trepat, James P Butler, Emil Millet, Kathleen G Morgan, David A Weitz, and Jeffrey J Fredberg. Fast and slow dynamics of the cytoskeleton. Nature materials, 5(8):636-640, 2006. 
[12] Nicolas Desprat, Alain Richert, Jacqueline Simeon, and Atef Asnacios. Creep function of a single living cell. Biophysical Journal, 88(3):2224-2233, 2005.

[13] Marcel Philippi Dorta. Propridades físicas que desencadeiam alterações mecânicas em células vivas. Master's thesis, Instituto de Física - Universidade de São Paulo, 2014.

[14] Ben Fabry, Geoffrey N Maksym, James P Butler, Michael Glogauer, Daniel Navajas, and Jeffrey J Fredberg. Scaling the microrheology of living cells. Physical review letters, 87(14):148102, 2001.

[15] Ben Fabry, Geoffrey N Maksym, James P Butler, Michael Glogauer, Daniel Navajas, Nathan A Taback, Emil J Millet, and Jeffrey J Fredberg. Time scale and other invariants of integrative mechanical behavior in living cells. Physical Review E, 68(4):041914, 2003.

[16] Ben Fabry, Geoffrey N Maksym, Stephanie A Shore, Paul E Moore, Reynold A Panettieri, James P Butler, and Jeffrey J Fredberg. Selected contribution: time course and heterogeneity of contractile responses in cultured human airway smooth muscle cells. Journal of Applied Physiology, 91(2):986-994, 2001.

[17] William N Findley and Francis A Davis. Creep and relaxation of nonlinear viscoelastic materials. Courier Corporation, 2013.

[18] Jeffrey Fredberg and Ben Fabry. The cytoskeleton as a soft glassy material. Cytoskeletal Mechanics: Models and Measurements. MRK Mofrad and RD Kamm, editors. Cambridge University Press, Cambridge, NY, 2006.

[19] Ming Guo, Allen J Ehrlicher, Mikkel H Jensen, Malte Renz, Jeffrey R Moore, Robert D Goldman, Jennifer Lippincott-Schwartz, Frederick C Mackintosh, and David A Weitz. Probing the stochastic, motor-driven properties of the cytoplasm using force spectrum microscopy. Cell, 158(4):822-832, 2014.

[20] Jonathon Howard et al. Mechanics of motor proteins and the cytoskeleton. Sinauer Associates Sunderland, MA, 2001.

[21] S.B. Howell. Handbook of CCD Astronomy. Cambridge Observing Handbooks for Research Astronomers. Cambridge University Press, 2006.

[22] M Keller, J Schilling, and E Sackmann. Oscillatory magnetic bead rheometer for complex fluid microrheometry. Review of Scientific Instruments, 72(9):3626-3634, 2001.

[23] Guillaume Lenormand and Jeffrey J Fredberg. Deformability, dynamics, and remodeling of cytoskeleton of the adherent living cell. Biorheology, 43(1):1-30, 2006. 
[24] Guillaume Lenormand, Emil Millet, Ben Fabry, James P Butler, and Jeffrey J Fredberg. Linearity and time-scale invariance of the creep function in living cells. Journal of The Royal Society Interface, 1(1):91-97, 2004.

[25] RE Mahaffy, CK Shih, FC MacKintosh, and J Käs. Scanning probe-based frequencydependent microrheology of polymer gels and biological cells. Physical Review Letters, $85(4): 880,2000$.

[26] Kranthi K Mandadapu, Sanjay Govindjee, and Mohammad RK Mofrad. On the cytoskeleton and soft glassy rheology. Journal of biomechanics, 41(7):1467-1478, 2008.

[27] T. G. Mason, K. Ganesan, J. H. van Zanten, D. Wirtz, and S. C. Kuo. Particle tracking microrheology of complex fluids. Phys. Rev. Lett., 79:3282-3285, Oct 1997.

[28] T. G. Mason and D. A. Weitz. Optical measurements of frequency-dependent linear viscoelastic moduli of complex fluids. Phys. Rev. Lett., 74:1250-1253, Feb 1995.

[29] Thomas G. Mason. Estimating the viscoelastic moduli of complex fluids using the generalized stokes-einstein equation. Rheologica Acta, 39(4):371-378, Aug 2000.

[30] James L McGrath and C Forbes Dewey Jr. 9 cell dynamics and the actin cytoskeleton. This page intentionally left blank, page 170, 2006.

[31] Mariana Oshima Menegon. Caracterização reológica de redes poliméricas de actina: medição e modelagem numérica. Master's thesis, Instituto de Física - Universidade de São Paulo, 2015.

[32] Ralf Metzler and Joseph Klafter. The random walk's guide to anomalous diffusion: A fractional dynamics approach. 339:1-77, 122000.

[33] Daisuke Mizuno, Catherine Tardin, Christoph F Schmidt, and Frederik C MacKintosh. Nonequilibrium mechanics of active cytoskeletal networks. Science, 315(5810):370-373, 2007.

[34] Mohammad RK Mofrad. Rheology of the cytoskeleton. Annual Review of Fluid Mechanics, 41:433-453, 2009.

[35] Mohammad RK Mofrad and Roger D Kamm. Cytoskeletal mechanics: models and measurements in cell mechanics. Cambridge University Press, 2006.

[36] Giorgio Parisi. Brownian motion. Nature, 433(7023):221-221, 2005.

[37] Damien Robert, Thi-Hanh Nguyen, François Gallet, and Claire Wilhelm. In vivo determination of fluctuating forces during endosome trafficking using a combination of active and passive microrheology. PloS one, 5(4):e10046, 2010. 
[38] Marita L Rodriguez, Patrick J McGarry, and Nathan J Sniadecki. Review on cell mechanics: experimental and modeling approaches. Applied Mechanics Reviews, 65(6):060801, 2013.

[39] Noah Rosenblatt, Adriano M Alencar, Arnab Majumdar, Béla Suki, and Dimitrije Stamenović. Dynamics of prestressed semiflexible polymer chains as a model of cell rheology. Physical review letters, 97(16):168101, 2006.

[40] Mariana Sacrini Ayres Ferraz. Difusão anômala de microesferas em estruturas complexas. PhD thesis, Instituto de Física, Universidade de São Paulo, 2015.

[41] S.R.A. Salinas. Introdução a Física Estatística Vol. 09. EDUSP, 1997.

[42] S.R.A. Salinas. Einstein e a teoria do movimento browniano. Revista Brasileira de Ensino de Física, 27(2), 2005.

[43] J.M. Silva and J.A.S. Lima. Quatro abordagens para o movimento browniano. Revista Brasileira de Ensino de FÃsica, 29:25 - 35, 002007.

[44] Peter Sollich, Fran çois Lequeux, Pascal Hébraud, and Michael E. Cates. Rheology of soft glassy materials. Phys. Rev. Lett., 78:2020-2023, Mar 1997.

[45] Dimitrije Stamenović. Cell mechanics: two regimes, maybe three? Nature materials, 5 8:597-8, 2006.

[46] Björn Stuhrmann, Marina Soares e Silva, Martin Depken, Frederick C MacKintosh, and Gijsje H Koenderink. Nonequilibrium fluctuations of a remodeling in vitro cytoskeleton. Physical Review E, 86(2):020901, 2012.

[47] F Ziemann, J Rädler, and E Sackmann. Local measurements of viscoelastic moduli of entangled actin networks using an oscillating magnetic bead micro-rheometer. Biophysical Journal, 66(6):2210, 1994. 